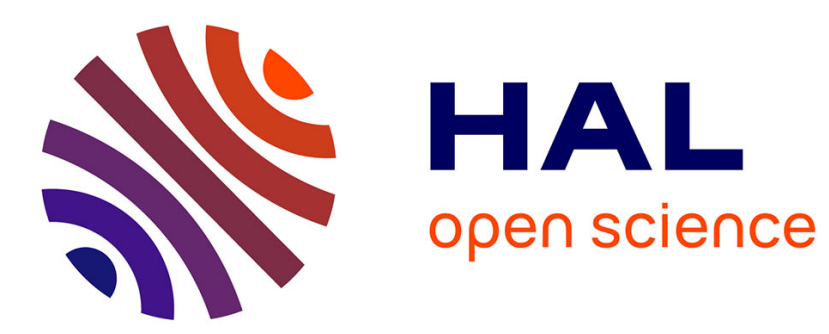

\title{
Market liquidity shortage and banks' capital structure and balance sheet adjustments: evidence from U.S. commercial Banks
}

\author{
Thierno Barry, Alassane Diabaté, Amine Tarazi
}

\section{To cite this version:}

Thierno Barry, Alassane Diabaté, Amine Tarazi. Market liquidity shortage and banks' capital structure and balance sheet adjustments: evidence from U.S. commercial Banks. 2019. hal-01965938v2

\section{HAL Id: hal-01965938 \\ https: / hal-unilim.archives-ouvertes.fr/hal-01965938v2}

Preprint submitted on 30 Apr 2019

HAL is a multi-disciplinary open access archive for the deposit and dissemination of scientific research documents, whether they are published or not. The documents may come from teaching and research institutions in France or abroad, or from public or private research centers.
L'archive ouverte pluridisciplinaire HAL, est destinée au dépôt et à la diffusion de documents scientifiques de niveau recherche, publiés ou non, émanant des établissements d'enseignement et de recherche français ou étrangers, des laboratoires publics ou privés. 


\title{
Market liquidity shortage and banks' capital structure and balance sheet adjustments: evidence from U.S. commercial Banks
}

\author{
Thierno Amadou Barry ${ }^{*}$, Alassane Diabaté ${ }^{*}$, Amine Tarazi ${ }^{* * *}$ \\ * Université de Limoges, LAPE, 5 rue Félix Eboué, 87031 Limoges Cedex, France \\ ** Institut Universitaire de France (IUF), 1 rue Descartes, 75231 Paris Cedex 05, France
}

This draft: April 26, 2019

\begin{abstract}
:
Using quarterly data of U.S. commercial banks, we investigate the impact of market liquidity shortages on banks' capitalization and balance sheet adjustments. Our findings reveal that an acute liquidity shortage leads small U.S. commercial banks, but not large ones, to positively adjust their total capital ratio. Small banks adjust their total capital ratio by downsizing, by restricting dividend payments, by decreasing the share of assets with higher risk weights and specifically by extending less loans. Furthermore, the positive impact on total capital ratios is stronger for small banks which are more reliant on market liquidity and small banks operating below their target capital ratio.
\end{abstract}

JEL Classification: 621, G28

Keywords: bank capital ratio, market liquidity shortage, capital structure adjustment

\footnotetext{
${ }^{1}$ Corresponding author. Tel: +33555149251

*Email Address: thierno-amadou.barry@unilim.fr (T. A. Barry), alassane.diabate@unilim.fr (A. Diabaté), amine.tarazi@unilim.fr (A. Tarazi)
} 


\title{
Market liquidity shortage and banks' capital structure and balance sheet adjustments: evidence from U.S. commercial Banks
}

\begin{abstract}
:
Using quarterly data of U.S. commercial banks, we investigate the impact of market liquidity shortages on banks' capitalization and balance sheet adjustments. Our findings reveal that an acute liquidity shortage leads small U.S. commercial banks, but not large ones, to positively adjust their total capital ratio. Small banks adjust their total capital ratio by downsizing, by restricting dividend payments, by decreasing the share of assets with higher risk weights and specifically by extending less loans. Furthermore, the positive impact on total capital ratios is stronger for small banks which are more reliant on market liquidity and small banks operating below their target capital ratio.
\end{abstract}

JEL Classification: G21, G28

Keywords: bank capital ratio, market liquidity shortage, capital structure adjustment 


\section{Introduction}

Holding enough capital allows banks to absorb losses, to be more solvent and therefore avoid bankruptcy. Capital requirements have hence become an essential tool to regulate banks by providing cushion during episodes of adverse financial conditions and by preventing banks from taking excessive risk ex ante. More specifically, during the global financial crisis of 20072009, systemic liquidity risk was a major contributor to bank failure as documented by Hong et al. 2014. Thus, while capital ratios are considered in the literature as an essential tool to reduce the risk of bank failure, systemic liquidity risk, which translates into a widespread market liquidity shortage, can also play a major role in triggering distress. Banks are therefore expected to take action during times of liquidity shortage by adjusting their balance sheets to improve their internal liquidity and namely their capital ratios to increase their financial strength. Banks could either downsize their overall activity to achieve lower leverage or substitute liquid assets to loans to improve their internal liquidity.

In this paper, we investigate how banks react in terms of capital structure adjustment to sharper conditions on the market leading to liquidity shortages. We capture episodes of such market liquidity shortages by sudden and sharp increases in commercial paper rates and specifically the TED spread, i.e. the difference between the three-month LIBOR and the threemonth T-bill interest rates. Although there is an extent literature focusing on the determinants of bank capital structure adjustment (e.g. Cohen and Scatigna, 2016; De Jonghe and Öztekin, 2015; Lepetit et al., 2015; Öztekin and Flannery, 2012; Memmel and Raupach, 2010; Berger et al., 2008) and a literature focusing on the relationship between capital and bank liquidity (see e.g. DeYoung et al., 2018; Castiglionesi et al., 2014; De Haan and Van Den End, 2013; Distinguin et al., 2013), how liquidity shortages affect the adjustment process remains an open question.

To figure out the different channels by which market liquidity shortages may impact banks' capital structure adjustment, we distinctively investigate the effect of such shortages on four aspects: first, on the share of risk weighted assets in total assets (substitution effect); second, on the share of loans in total assets (impact on lending); third, on total assets (possible downsizing) and fourth, on dividends (possible earnings retention). We also account for banks' degree of reliance on market liquidity. Indeed, banks that hold less liquid assets or with higher maturity mismatch between assets and liabilities may be differently affected by a liquidity shortage on the market than other banks. Their stronger reliance on market liquidity could urge them to take stronger actions to adjust their balance sheets. Moreover, banks operating below 
their target capital ratios might also behave differently than banks operating above their target. Such banks are expected to be under stronger pressure to adjust to their target. Eventually, because they are financially more constrained than large banks, small banks might also adjust differently.

The literature on the impact of market liquidity breakdowns on banks is scarce and the papers related to our study are far from being conclusive. Castiglionesi et al. (2014) show theoretically and empirically that banks facing undiversifiable liquidity risk, i.e. liquidity risk that banks cannot coinsure on interbank markets, tend to hold higher capital. In their setting banks less active on the interbank market hold higher capital. Meanwhile, Gatev and Strahan (2006) document a natural hedging behavior of banks against liquidity risk. They find that, during a liquidity disruption episode on the commercial paper market, bank deposits tend to grow. They argue that, during such episodes, because they are looking for a safe place, investors withdraw funds from markets and inject them into the banking system. In such a case, leverage would increase and banks would need to adjust their capital ratios to get closer to their target ratio. However, such a behavior is challenged by other studies. For instance, Pennacchi (2006) does not find any inflow of funds at banks during the pre-Federal Deposit Insurance Corporation (FDIC) period. This may be evidence that such inflows are caused by the government guarantees.

In our investigation, we use U.S. commercial banks' data over the 2000-2014 period and find only small banks to positively adjust their capital ratios when facing liquidity shortages on the market. Large banks neither increase nor decrease their capital ratios. Small banks positively adjust their capital ratios by reducing the share of loans in total assets, by decreasing the share of assets with higher risk weights, by restricting dividend payments and by downsizing their overall balance sheets. Our results also indicate that the extent to which small banks adjust their capital ratios when facing difficulties in accessing liquidity is not uniform. Less liquid small banks and small banks operating below their target capital ratios react more strongly than other small banks. By investigating whether market liquidity shortages impact banks' capital structure adjustment we contribute to both the capital structure adjustment literature and the banking literature. More specifically, we present empirical evidence that market liquidity shortage is an important determinant of bank capital structure adjustment. To our knowledge, this is the first paper that investigates such an issue which is of major importance for bank regulation. Our findings indicate that liquidity requirements imposed at the individual bank level as defined in Basel III might not be necessary for small banks but appear to be crucial for 
large banks. This is because small banks take action to improve their solvency when facing a liquidity shortage on the market, which is not the case of large banks.

The remainder of the paper is organized as follows. In section 2, we present our data and the methodology and section 3 discusses the results. Section 4 looks at further issues and section 5 provides robustness checks. Section 6 concludes.

\section{Data and Methodology}

\subsection{Presentation of the sample}

We obtain the data used in this study from two different sources. We extract data to compute our measures of market liquidity shortage and data on GDP from the federal reserve bank of St Louis $^{2}$. Data on balance sheets and income statements come from SNL Financial. We use a sample consisting of an unbalanced panel of quarterly data from 2000 to 2014 for U.S. commercial banks which includes 10053 banks making 438,608 bank-quarter observations. These banks are the ones that provide information on their total assets on at least one quarter in our investigation period and have a total capital ratio higher than the minimum level required by regulation $(8 \%)$. We exclude banks with a total capital ratio under the minimum required level because they might behave differently than their peers and disturb our analysis. Such banks would obviously be under regulatory pressure to enhance their capital ratio. We also split our sample into two subsamples of small and large banks. Following the literature, we consider banks with total assets higher than $\$ 1$ billion to be large and small banks are those with total assets lower or equal to $\$ 1$ billion. To deal with the issue of possible outliers, we winsorize our variables at the $2^{\text {nd }}$ and $98^{\text {th }}$ percentiles.

\subsection{Definition of variables}

The purpose of this paper is to investigate if market liquidity shortages affect banks' capital structure adjustment and the channels through which capital ratios are affected.

\subsubsection{Total capital ratio}

Our main dependent variable is the total capital ratio. The total capital ratio is the sum of Tier 1 capital and Tier 2 capital divided by total risk weighted assets. Tier 1 capital is the bank's core capital. It includes equity and published reserves while Tier 2 capital mainly

\footnotetext{
${ }^{2}$ See http://research.stlouisfed.org/
} 
includes subordinated debt and undisclosed reserves. We also use the Tier 1 capital ratio as an alternative dependent variable for robustness checks.

\subsubsection{Proxies of market liquidity shortage}

We use two different interest spreads to proxy market liquidity shortage.

Firstly, we follow Hong et al. (2014), Rodríguez-Moreno and Peña (2013), Wu and Hong (2012) and Cornett et al. (2011) and use the TED spread. Cornett et al. (2011) use the TED spread to measure liquidity strains on the banking system while Wu and Hong (2012) and Hong et al. (2014) use it to measure systemic liquidity risk. Rodríguez-Moreno and Peña (2013) use it to, more broadly, proxy systemic risk. The TED spread is the difference between the three-month London Interbank Offered Rate (LIBOR) and the three-month Treasury bills rate. It is used as a gauge of financial health. LIBOR is the unsecured interest rate on interbank loans and allows to perceive liquidity constraints and stress on the interbank market while the Treasury bill rates provide information about changes in macroeconomic conditions and monetary policy. In addition, because during periods of stress only government securities are accepted as collateral, Treasury bill rates tend to decrease. Therefore, in addition to information on liquidity risk and credit risk, the TED spread reflects flight-to-quality effects. Secondly, for robustness checks, we follow Gatev and Strahan (2006) and use the commercial paper spread. Gatev and Strahan (2006) use spikes in the commercial paper spread to measure financial market disruptions. The commercial paper spread is a spread between the three-month commercial paper rate for highly rated (AA) non-financial borrowers and the three-month Treasury bills rate. Commercial paper is an unsecured, short-term debt instrument (up to 270 days of maturity) issued by investment-grade corporations.

Spikes in both proxies (TED spread and commercial paper spread) highlight liquidity disruptions in the market. We therefore create a dummy variable $M L S_{t}$ based on either the TED spread or the commercial paper spread. The dummy variable is equal to one if the observation is above its $75^{\text {th }}$ percentile throughout the entire sample period and zero otherwise. We assume that spikes beyond the $75^{\text {th }}$ percentile underline liquidity disruptions on the market. To check for robustness, we also use alternative thresholds (the $90^{\text {th }}$ percentile and the mean plus two times the standard deviation).

\subsubsection{Extent of reliance on market liquidity}

During periods of liquidity stress, banks with lower liquidity ratios might behave differently than banks which are less reliant on the market. To gauge the extent to which banks 
are dependent on the market, we follow the Basel III principles and compute the Net Stable Funding Ratio (NSFR) using the weights defined in DeYoung and Jang (2016) ${ }^{3}$. The Net Stable Funding Ratio is a liquidity standard established in 2010 by the Committee on Banking Supervisory (BCBS) to strengthen bank stability. It is calculated by dividing the amount of available stable funding by the amount of required stable funding. It can be defined as the proportion of long-term assets funded by long term or stable funding. Fully implemented since January 2019 , banks need to set this ratio at a minimum of $100 \%$ to maintain a stable funding profile enabling them to sustain a liquidity crisis. In our investigation, we assume that less liquid banks are those whose NSFR is below $100 \%$. Therefore, to capture such banks, we define a dummy variable $Z_{i, t}$ that is equal to one if bank $i$ has a NSFR lower than $100 \%$ at time $t$ and zero if otherwise.

For robustness checks, we also use an alternative threshold for NSFR $\left(10^{\text {th }}\right.$ percentile) and three alternative variables to proxy banks' liquidity level. We use the loans to core deposits ratio assuming that banks with more than $100 \%$ of this ratio, are more exposed to liquidity shortages on the market. We also use the liquid assets to total assets ratio and we assume that banks that are below the $25^{\text {th }}$ percentile $(12.85 \%)$ of this ratio, are less liquid banks. Finally, we account for the extent to which banks rely on wholesale funding. We use the proxy of reliance on wholesale funding defined in SNL Financial. This proxy is calculated by dividing the sum of total borrowings and brokered deposits by the sum of total borrowings and total deposits. It depicts the portion of a bank's total funds that are from wholesale sources. We assume that banks are strongly reliant on wholesale funding if they are above the $75^{\text {th }}$ percentile $(12.35 \%)$ of this proxy.

\subsubsection{Banks' capital ratio target}

When facing a market liquidity squeeze, banks operating below their target total capital ratio may take stronger action to increase their capital ratio than banks operating above their target ratio. We therefore account for whether a bank is below or above its target capital ratio.

We model the target capital ratio as a function of banks' observable characteristics (e.g. De Jonghe and Öztekin, 2015 and Lepetit et al. 2015; Gropp and Heider, 2010; Lemmon et al.,2008; Flannery and Rangan, 2006):

$$
T C R_{i, t}^{*}=\beta X_{i, t-1}
$$

\footnotetext{
${ }^{3}$ see APPENDIX K for detailed components.
} 
where $T C R_{i, t}^{*}$ is the target total capital ratio; $X_{i, t-1}$ is a vector of variables that determine the target level of the total capital ratio. The vector includes a dummy for market liquidity shortage, a dummy for mergers and acquisition, the GDP growth rate to account for macroeconomic factors that impact all banks, proxies for banks' performance (return on assets), credit risk (nonperforming loans to total loans), liquidity (NSFR) and size (natural logarithm of total assets). $\beta$ is the vector of coefficients of the variables included in $X_{i, t-1}$.

Banks cannot adjust their capital ratio instantaneously and need time to reach the target level. Thus, we build a partial adjustment framework to take the cost of adjustment into account:

$$
\Delta T C R_{i, t}=\lambda\left(T C R_{i, t}^{*}-T C R_{i, t-1}\right)+\varepsilon_{i, t}
$$

where $\lambda$ is a scalar adjustment speed $(0<\lambda<1)$ and $T C R_{i, t}^{*}$ is the target capital ratio of bank $i$ at time $t$. Substituting equation (1) into equation (2) and rearranging give the following estimation model:

$$
T C R_{i, t}=\lambda \beta X_{i, t-1}+(1-\lambda) T C R_{i, t-1}+\varepsilon_{i, t}
$$

Equation (3) includes the lagged dependent variable. Nickell (1981) shows that the presence of the lag dependent variable generates correlation between the regressor and the error term which leads to a bias in the coefficient estimates, which will be inconsistent (Shim, 2012). To fix this problem, Arellano and Bond (1991), Anderson and Hsiao (1982) and Blundell and Bond (1998) propose General Method of Moment (GMM) estimation procedures. However, when the time dimension $\mathrm{T}$ is relatively large, the bias becomes insignificant (Roodman, 2006, 2009) and the standard estimation procedures are asymptotically valid (kiviet, 1995). For instance, when the time dimension $\mathrm{T}$ is greater than 30, Judson and Owen (1999) document that fixed effects estimators perform better than GMM estimators. Loutskina (2011) indicates that the bias becomes problematic when $\mathrm{T}$ falls below 15 time periods. Our investigation period stems from 2000Q1 to 2014Q4 making 60 time periods. Therefore, like other studies such as Kim and Sohn (2017) and Berrospide and Edge (2010), we use fixed effect estimations after performing Hausman tests which validate the use of fixed effects versus random effects. Finally, we cluster standard errors at the bank level (see APPENDIX A for results). We recover $\beta$ by dividing $\widehat{\lambda \beta}$ by $\hat{\lambda}$ and we recover $\hat{\lambda}$ from $\widehat{1-\lambda}$. We can then use equation (1) to compute the estimated 
target total capital ratio for each bank $i$ at time $t$. We use the estimated target capital ratio to compute the capital ratio deviation as follows:

$$
G A P_{i, t-1}=T C R_{i, t}^{*}-T C R_{i, t-1}
$$

Banks operating below their target capital ratio are the ones with a positive gap. To capture such banks, we create a dummy variable that is equal to one if $G A P_{i, t-1}>0$ and zero if otherwise. For robustness checks, we follow the same procedure to capture banks operating below the level of the Tier 1 capital ratio they target.

\subsubsection{Descriptive statistics}

Table 1 presents the definitions and descriptive statistics of all the variables used in this investigation. The TED spread and the commercial paper spread, on average over the sample period, are respectively $0.46 \%$ and $0.33 \%$ with relatively high standard deviations ${ }^{4}$. The lowest value of the total capital ratio in our sample is $9.84 \%$ and the lowest value of the estimated target total capital ratio is $8.73 \%$, which is higher than the minimum regulatory requirement consistent with the fact that banks' targets include buffers to prevent them from falling below the threshold in case of negative shocks and possibly face regulatory sanctions. On average, the ratio of liquid assets to total assets is equal to $24.32 \%$ and the NSFR is around $84 \%$ which is below the $100 \%$ that banks need to comply with. On average, the loans to core deposits ratio and the portion of wholesale funding in total funding are $78.44 \%$ and $8.23 \%$ respectively. On average, banks grew in size during our investigation period. Their balance sheets are also dominated by risky assets. The mean of risk-weighted assets over total assets is $67.71 \%$. The correlation matrix (Appendix J) does not indicate major collinearity issues.

[insert table 1, graph $1 \&$ graph 2]

\subsection{Empirical specifications}

Since the aim of this study is to investigate whether market liquidity shortage impacts banks' capital structure adjustment, we use an adjustment model. We observe at time $t$, a change

\footnotetext{
${ }^{4}$ See graph 1 and graph 2.
} 
in bank $i$ 's capital ratio and link it to a market liquidity shortage occurring at time $t-1$. The total capital ratio can be increased by increasing capital (numerator) and/or decreasing risk weighted assets (denominator). To increase capital, a bank can either issue equity or increase retained earnings by reducing dividend payments. However, the cost of capital may be higher during liquidity squeezes and furthermore issuing capital may also be interpreted as a bad signal and generate a decrease in the bank's value (see Myers and Majluf, 1984). Banks might therefore be reluctant to issue equity during such episodes ${ }^{5}$. Hence, to figure out the different channels in which market liquidity shortage may impact U.S. commercial banks' total capital ratio, we study the effect of such shortage on $1 /$ the change in the share of risk weighted assets in total assets, 2/ the change in the share of loans in total assets, $3 /$ the change in total assets and 4/ dividend payments to total assets ${ }^{6}$. Banks could increase their total capital ratio by restricting dividend payouts, changing the composition of their assets to reduce the level of risk weighted assets, selling assets or reducing loans (downsizing). The empirical specifications are therefore given by:

$$
\begin{gathered}
Y_{i . t}=\alpha_{i}+\xi_{t}+\varphi_{1} M L S_{t-1}+\varphi_{2} Z_{i, t-1}+\varphi_{3} d u m m y \_g a p_{i, t-1} \\
+\varphi_{4}\left(Z_{i, t-1} * M L S_{t-1}\right)+\varphi U_{i . t-1}+\eta_{i . t} \\
Y_{i . t}=\gamma_{i}+\theta_{t}+\omega_{1} M L S_{t-1}+\omega_{2} Z_{i, t-1}+\omega_{3} d u m m y_{-} g a p_{i, t-1} \\
+\omega_{4}\left(\text { dummy_gap }_{i, t-1} * M L S_{t-1}\right)+\omega U_{i . t-1}+\mu_{i . t}
\end{gathered}
$$

where $Y_{i . t}$ is either the change in the total capital ratio, the change in the share of risk weighted assets in total assets, the change in the share of loans in total assets, the change in total assets or the dividend to total assets ratio; $\alpha_{i}$ and $\gamma_{i}$ are individual bank fixed effects and $\xi_{t}$ and $\theta_{t}$ are time fixed effects; $M L S_{t-1}$ is a dummy variable that is equal to one if throughout the whole period, the TED spread is higher than its $75^{\text {th }}$ percentile at time t- 1 and zero if otherwise, $Z_{i, t-1}$ is a dummy variable that is equal to one if bank $i$ is more reliant on market liquidity at time $\mathrm{t}-1$ and zero if otherwise; dummy_gap $p_{i, t-1}$ is a dummy variable equal to one if $G A P_{i, t-1}>0$ and zero if otherwise; $U_{i . t-1}$ is a vector of bank specific variables for bank $i$ at time $t-1$. It includes

\footnotetext{
${ }^{5}$ We investigate the impact of market liquidity shortages on the quarterly growth rate of equity and do not find significant results.

${ }^{6}$ We also use the ratio of dividends to net income and the ratio of retained earnings to total assets and obtain similar findings.
} 
the GDP growth rate to capture the business cycle, bank size proxied by the natural logarithm of total assets, the return on assets to account for banks' performance, the ratio of nonperforming loans to total loans to measure risk in the bank's loan portfolio and a dummy to control for the effect of mergers and acquisitions. This dummy variable is equal to one if a bank's total assets grow by more than $10 \%$ during a given quarter and zero if otherwise.

$\varphi_{1}$ captures the impact of market liquidity shortages on the dependent variable for banks less reliant on market liquidity. We expect it to be either non-significant or significant and positive. Indeed, since their bank holds more liquidity or is less exposed to maturity transformation risk, managers may not feel concerned by the liquidity shortage on the market and therefore they may not take action to adjust their total capital ratio and balance sheets more generally. In that case, $\varphi_{1}$ will be non-significant. However, if these managers are very cautious, they may increase their total capital ratio. In that case, $\varphi_{1}$ is expected to be positive and significant when the dependent variable is the change in the total capital ratio.

$\omega_{1}$ gives the impact of market liquidity shortages on the dependent variable for banks operating above their target capital ratio. We also expect it to be either non-significant or significant and positive. Indeed, the managers of banks operating above their target capital ratio may not adjust their capital ratio and balance sheet because they might feel safe and already well capitalized. In that case $\omega_{1}$ will be non-significant. However, if the managers of such banks are very cautious, they may adjust their capital ratio positively. In that case, $\omega_{1}$ is expected to be positive and significant when the dependent variable is the change in the total capital ratio.

$\varphi_{2}$ and $\omega_{2}$ capture the impact on the dependent variable of banks' reliance on market liquidity in the absence of a market liquidity shortage. $\varphi_{2}$ and $\omega_{2}$ are expected to be positive, when the dependent variable is the change in the total capital ratio, because stronger reliance on market liquidity leads banks to increase their capital ratio to exhibit higher solvency to more easily borrow from the market. As documented by DeYoung et al. (2018), U.S. commercial banks treat liquidity and regulatory capital as substitutes. Distinguin et al. (2013) also find that small U.S. banks increase their regulatory capital ratios when they are exposed to higher illiquidity.

$\varphi_{3}$ and $\omega_{3}$ capture the impact of operating below the target capital ratio on the dependent variable in the absence of market liquidity shortage. We expect $\varphi_{3}$ and $\omega_{3}$ to be positive and significant, when the dependent variable is the change in the total capital ratio, because banks operating below their target capital ratio, are expected to increase their capital ratio to get closer to their target. 
$\varphi_{4}$ captures the additional impact of market liquidity shortage on the dependent variable for banks more reliant on market liquidity compared to less reliant ones. We expect it to be positive and significant, when the dependent variable is the change in the total capital ratio, because banks more reliant on market liquidity should more extensively increase their capital ratio than their less market-reliant peers. Similarly, $\omega_{4}$ gives the additional impact of market liquidity shortage on the dependent variable of banks operating below their target capital ratio compared to those operating above their target ratio. We also expect it to be positive and significant, when the dependent variable is the change in the total capital ratio, because banks below their target capital ratio will react more promptly and to a larger extent. Consistently, we also expect $\left(\varphi_{1}+\varphi_{4}\right)$ and $\left(\omega_{1}+\omega_{4}\right)$ to be significantly positive.

\section{Results}

In this paper, we investigate the impact of market liquidity shortage on banks' capital structure adjustment and the channels through which the total capital ratio is impacted. Since our investigation period is 2000-2014, our results may be influenced by the global financial crisis of 2007-2008 and government interventions ${ }^{7}$ during the crisis. Therefore, in addition to estimating our regressions on the whole investigation period, we also conduct estimations by excluding the crisis period. Tables 2 and 3 give the results on the whole investigation period and tables 4 and 5 give the results after excluding the crisis period. We use the fixed-effect method $^{8}$ and cluster standard errors at the bank level.

Overall, we find that market liquidity shortage does not impact the change in the total capital ratio of large banks, regardless of how much they rely on market liquidity or how far they are below their target capital ratio $\left(\varphi_{1}, \omega_{1},\left(\varphi_{1}+\varphi_{4}\right)\right.$ and $\left(\omega_{1}+\omega_{4}\right)$ are not significant for large banks in $\triangle \mathrm{TCR}$ equations). However, although $\varphi_{1}$ is significant at $10 \%$ during normal times for small banks in the $\triangle \mathrm{TCR}$ equation and in the $\triangle \mathrm{RWA}$ equation, the results show that small banks respond to market liquidity shortage by positively adjusting their total capital ratio. Such banks do so by decreasing the share of risk weighted assets in total assets, by reducing the share of loans in total assets and by downsizing their balance sheets.

\footnotetext{
${ }^{7}$ The U.S. Treasury made approximately $\$ 220$ billion of capital injections through the Capital Purchase Program. The Federal Reserve implemented several facilities to provide significant amounts of liquidity to the banking system. These facilities include the Asset-Backed Commercial Paper Money Market Mutual Fund Liquidity Facility (AMLF), the commercial Paper Funding Facility (CPFF), the Money Market Investor Funding Facility (MMIFF), the Term Securities Lending Facility (TSLF) and the Primary Dealer Credit Facility (PDCF).

${ }^{8}$ We perform Hausman tests which validate the use of fixed effects versus random effects.
} 
Furthermore, the impact on the total capital ratio is stronger for small banks that are more reliant on market liquidity $\left(\left(\varphi_{1}+\varphi_{4}\right)>\varphi_{1}\right)$ in the $\Delta \mathrm{TCR}$ equation). They also reduce the share of risk weighted assets in total assets by a larger extent and cut loans more extensively than small banks which are less reliant on market liquidity $\left(\left(\varphi_{1}+\varphi_{4}\right)<\varphi_{1}\right)$ in $\Delta$ LOANS equation and $\Delta$ RWA equation). Similarly, small banks operating below their target total capital ratio increase their total capital ratio more significantly than their peers operating above their target ratio $\left(\left(\omega_{1}+\omega_{4}\right)>\omega_{1}\right.$ in $\triangle \mathrm{TCR}$ equation). They also tend to reduce their risk weighted assets (and hence their loans) to a larger extent than small banks operating above their target total capital ratio $\left(\left(\omega_{1}+\omega_{4}\right)<\omega_{1}\right)$ in $\Delta$ LOANS equation and $\Delta$ RWA equation).

We also find that market liquidity shortages do not negatively impact the dividend to total assets ratio of small banks. Hence, banks do not seem to rely on retained earnings to increase their capital ratio 9 .

Our results are also economically meaningful. For small banks less reliant on market liquidity, a one-standard deviation increase in MLS increases $\triangle \mathrm{TCR}$ by 0.263 which takes the mean from -0.150 to +0.113 . A one-standard deviation increase in MLS also takes the mean of $\triangle$ LOAN from +0.11 to -0.346 and the mean of $\Delta \mathrm{RWA}$ from +0.09 to -0.332 . These changes are more important for banks more reliant on market liquidity. A one-standard deviation increase in MLS leads to a variation of the mean of $\Delta \mathrm{TCR}$ from -0.150 to +0.286 , to a variation of the mean of $\Delta \mathrm{LOAN}$ from +0.11 to -0.58 and to a variation of the mean of $\Delta \mathrm{RWA}$ from +0.09 to -0.622 .

For small banks operating above their target capital ratio, a one-standard deviation increase in MLS increases $\triangle \mathrm{TCR}$ by +0.321 and this change is more important for banks operating below their target capital ratio $(+0.471)$. A one-standard deviation increase in MLS leads, for banks operating above their target capital ratio, to a mean of $\triangle \mathrm{LOAN}$ and $\triangle \mathrm{RWA}$ equal to -0.435 and -0.418 respectively. These changes are also larger for banks operating below their target capital ratio (-0.597 and -0.713 for $\triangle \mathrm{LOAN}$ and $\Delta \mathrm{RWA}$ respectively).

On the whole, these results show that only small banks react to liquidity squeeze by adjusting their balance sheets and by downsizing and cutting lending ${ }^{10}$ which enhances their total capital ratio. Nevertheless, this capital ratio improvement is stronger for small banks more reliant on market liquidity and small banks operating below their target capital ratio. Small banks may be adjusting their capital ratio positively because their confidence in the market decreases and/or

\footnotetext{
${ }^{9}$ A deeper investigation shows that small banks make cuts to their dividend payments during sharper episodes of liquidity squeeze as highlighted in the next section.

${ }^{10}$ This result is in line with the literature that underlines the negative effect of liquidity shocks on bank lending (Dombret et al. (2018), Chouchène et al. (2017), Allen et al. (2014), Calem et al. (2013), De Haas and Van Horen (2013), Schnabl (2012), Puri et al. (2011), Ivashina and Scharfstein (2010), Peek and Rosengren (1997)).
} 
they need to show stronger financial strength or hedge against possible losses (Ramos, 1996). They might also behave as such for precautionary reasons to avoid falling under the minimum regulatory level of the capital ratio. By reducing their default risk (higher capital ratio), banks could also be aiming to avoid a higher cost of uninsured deposits by limiting the higher premium required by depositors (Fonseca and González, 2009) or the likelihood of a bank run (Dermine, 2015). Most strikingly, small banks are the only ones to behave as such. Large banks' capital ratios and balance sheets more generally do not at all react to liquidity shortages possibly because they have easier access to fed funds under any circumstances and because their "toobig-to-fail" status enables them to benefit from government support which is not the case for small banks.

[insert tables 2,3, $4 \&$ table 5]

\section{Further issues}

4.1.Severe market liquidity shortage

In the main regressions, to capture market liquidity shortages, we use a dummy variable equal to one if the TED spread is higher than its $75^{\text {th }}$ percentile. Now, instead of the $75^{\text {th }}$ percentile we consider more restrictive conditions to capture severe cases of liquidity shortage on the market: $90^{\text {th }}$ percentile and the mean plus two times the standard deviation. The results are presented in appendix B, tables 1B, 2B, 3B and 4B. They are consistent with our main results. Although we are considering sharper episodes of liquidity squeeze the capital ratios of large banks are still not impacted and the results for small banks are similar to the ones we had before. Interestingly such more severe episodes make small but not large banks reduce their dividend payments which further contributes to improve their capital ratios. As to large banks, their lending activities are negatively impacted and their size also diminishes (decrease in total assets). However, such impacts are not strong enough to affect their capital ratios.

4.2.Do banks respond to market liquidity shortage by increasing their liquidity ratio?

We document in this paper that small banks improve their capital ratio by downsizing, cutting lending, reducing their risk weighted assets and by decreasing their dividend payouts. However, another plausible channel to improve capital ratios could be the increase in liquidity ratios. Banks could indeed react to market liquidity shortage by increasing their liquidity which 
could in turn "mechanically" increase their capital ratio. We hence investigate such possible behavior.

Tables $5 \mathrm{~B}$ and $6 \mathrm{~B}$ show the results of the regressions with the change in the ratio of liquid assets to total assets as the dependent variable. The results show that market liquidity shortage does not affect large banks' liquidity ratios. In addition, although the interaction term is significant for small banks, the Wald test $\mathrm{p}$ values show that $\left(\varphi_{1}+\varphi_{4}\right)$ and $\left(\omega_{1}+\omega_{4}\right)$ are not significant and the null hypothesis cannot be rejected for $\varphi_{1}$ and $\omega_{1}$. Thus, as for large banks, market liquidity shortage does not impact the change in the ratio of liquid assets to total assets of small banks regardless of their degree of reliance on market liquidity and whether they are above or below their target capital ratio. Therefore, the improvement in capital for small banks is not achieved via an increase in their holdings of liquid assets.

\subsection{Small banks' adjustment speed during market liquidity shortage episodes}

Our results show that market liquidity shortage leads small banks to positively adjust their total capital ratio. In this sub-section, we investigate the speed with which such banks adjust their total capital ratio during a period of market liquidity shortage. We express the adjustment speed as follows (e.g. Öztekin and Flannery, 2012; DeYoung et al., 2018):

$$
\lambda_{i, t}=\Lambda V_{i, t-1}
$$

Where $\lambda_{i, t}$ is the bank-specific, time-varying adjustment speed toward the target capital ratio; $V_{i, t-1}$ is a vector of bank and time period characteristics that affect the speed of adjustment and $\Lambda$ is a vector of coefficients to be estimated. Substituting equation (9) into (2) yields the following equation:

$$
\Delta T C R_{i, t}=\Lambda V_{i, t-1}\left(T C R_{i, t}^{*}-T C R_{i, t-1}\right)+\varepsilon_{i, t}
$$

Rewriting equation (10) and using equation (4) yields:

$$
\triangle T C R_{i, t}=\Lambda V_{i, t-1} G A P_{i, t-1}+\varepsilon_{i, t}
$$

We account for bank fixed effects and quarterly time fixed effects and we estimate equation (11) using ordinary least squares ${ }^{11}$.

\footnotetext{
${ }^{11}$ we follow Öztekin and Flannery (2012) and DeYoung et al. (2018).
} 
The results (see appendix B, table 7B) show that during times of market liquidity shortage, small banks more reliant on market liquidity adjust faster than small less reliant banks. Small banks operating below their target total capital ratio also adjust faster than small banks operating above their target total capital ratio. We find that the speed of adjustment of small banks more reliant on market liquidity is $0.0675 \%$ faster than the speed of adjustment of small banks less reliant on market liquidity and the adjustment speed of banks operating below their target capital ratio is $0.126 \%$ faster than at banks operating above their target capital ratio.

\section{Robustness checks}

We perform several robustness checks. First, in our baseline regression, we consider a bank to be relatively less liquid if its NSFR is lower than $100 \%$. However, because the NSFR was introduced in the Basel III accords in 2010 and because banks were supposed to gradually come into compliance with these requirements from 2015 to 2019, we take a lower threshold because banks might not have considered falling below $100 \%$ as a threat. We assume that less liquid banks are the ones whose NSFR is lower than the $10^{\text {th }}$ percentile of NSFR $(27.92 \%)$. The obtained results are consistent with those of the baseline regression (see appendix C).

In addition, we use alternative variables to NSFR to measure banks' liquidity level. These alternative variables are $\mathrm{i} /$ reliance on wholesale funding, ii/ total liquid assets to total assets ratio and iii/ loans to core deposits ratio ${ }^{12}$ (see APPENDIX D). The obtained results are in line with our main results.

We also limit our sample to banks that are strongly focused on intermediation activities that we name "real commercial banks" by only including banks with total deposits to total assets ratio and total loans over total assets higher than $30 \%$. These banks are more exposed to liquidity risk since liquidity risk mostly emanates from exposures linked to intermediation activities (undrawn loan commitments, demand deposits, withdrawal of funds from wholesale deposits...). Considering this restricted sample of "real commercial banks", our findings remain unchanged (see APPENDIX E).

Moreover, in our baseline regressions we have included the crisis period by conducting estimations using the $75^{\text {th }}$ percentile of the TED spread throughout the whole sample period. Instead, we construct our proxy of market liquidity shortage by using the $75^{\text {th }}$ percentile of TED spread throughout normal times only. We also use the $90^{\text {th }}$ percentile and the mean plus two

\footnotetext{
${ }^{12}$ See tables 1 for variables definitions.
} 
times the standard deviation. The results obtained are consistent with our main results (see APPENDIX F).

Our results indicate that large banks do not adjust their total capital ratio during periods of high pressure on the liquidity market. Therefore, we look deeper and investigate whether their behavior can be explained by differences in risk management sophistication. Large banks with sophisticated risk management tools may not increase their total capital ratio because they can more easily cope with such shortage episodes while those with poorer risk management tools might positively react. As a proxy of risk management sophistication, we use the notional value of the interest rate swap and futures contracts committing the reporting institution to purchase or sell equity securities. We consider that banks above the median of these variables have better risk management practices (median equals 0). APPENDIX $G$ displays the results of our estimations. We find similar results for all type of large banks. Large banks with a better risk management technology do not behave differently than their less sophisticated peers.

In addition, we check if our results are robust to various definitions of the capital ratio. Instead of the total capital ratio we use the Tier 1 capital ratio. Tier 1 capital represents a bank's core capital. The obtained results are consistent with our main results (see APPENDIX H). In addition, we estimate the target Tier 1 capital ratio (TIER_ONE $i, t$ ) for each bank $i$ at time $t$. We use the estimated target Tier 1 capital ratio to compute the deviation as:

$$
G A P_{-} T I E R_{i, t-1}=T I E R_{-} O N E_{i, t}^{*}-T I E R_{-} O N E_{i, t-1}
$$

We then isolate banks operating below their target Tier 1 capital ratio and perform estimations to check if our results found for banks operating below (above) their target total capital ratio are robust. Again, our main findings remain unchanged.

Finally, instead of the TED spread, we use the commercial paper spread to proxy market liquidity shortage. Our results remain unchanged (see APPENDIX I).

\section{Conclusion}

Using an unbalanced panel database of U.S. commercial banks, we investigate the influence of episodes of liquidity squeeze on the market on their capital ratios and balance sheet adjustments. We specifically focus on the different channels that affect their total capital ratio. We also account for size, reliance on market liquidity and gap between banks' actual and target capital ratios. Overall, our findings highlight that only small banks react to market liquidity shortage by increasing their total capital ratio. To improve their capital ratio, small banks downsize, decrease their dividend payouts, cut lending and reduce their share of risk weighted 
assets in total assets. This improvement in the capital ratio is stronger at small banks more reliant on market liquidity and small banks operating below their target capital ratio.

In addition to liquidity requirements, reducing leverage and holding higher capital ratios by substituting less risky assets for riskier ones is one of the multiple ways to hedge against a liquidity squeeze. Thus, liquidity requirements might be redundant for small banks because they take action to improve their solvency standards, but necessary for large banks. 


\section{References}

Allen, F., Hryckiewicz, A., Kowalewski, O., Tümer-Alkan, G., 2014. Transmission of bank liquidity shocks in loan and deposit markets: role of interbank borrowing and market monitoring. Journal Financial Stability 15, 112-126.

Anderson, T., W., Hsiao, C., 1982. Formulation and estimation of dynamic models using panel data. Journal of Econometrics 18 (1), 47-82.

Arellano, M., Bond, S., 1991. Some tests of specification for panel data: Monte Carlo evidence and an application to employment equations. Review of Economic Studies 58, 277297.

Berger, A., DeYoung, R., Flannery, M., Lee, D., Öztekin, Ö., 2008. How do large banking organizations manage their capital ratios? Journal of Financial Services Research 34 (2), 123 149.

Berrospide, J., M., Edge, R., M., 2010. The effects of bank capital on lending: What do we know, and what does it mean? International Journal of Central Banking, 5-54.

Blundell, R., Bond, S., 1998. Initial conditions and moment restrictions in dynamic panel data models. J. Econometrics 87, 115-143.

Calem, P., Covas, F., Wu, J., The impact of the 2007 liquidity shock on bank jumbo mortgage lending. Journal of Money, Credit and Banking 45, 59-91.

Castiglionesi, F., Feriozzi, F., Loranth, G., Pelizzon, L., 2014. Liquidity coinsurance and bank capital. Journal of Money, Credit and Banking 46, 409-443.

Chouchène, M., Ftiti, Z., Khiari, W., 2017. Bank-to-bank lending channel and the transmission of bank liquidity shocks: Evidence from France. Research in International Business and Finance 39 (B), 940-950.

Cohen, B., H., Scatigna, M., 2016. Banks and capital requirements: channels of adjustment. Journal of Banking and Finance 69(S1), S56-S69.

Cornett, M., M., McNutt, J., J., Strahan, P., E., Tehranian, H., 2011. Liquidity risk management and credit supply in the financial crisis. Journal of Financial Economics 101 (2), $297-312$

De Haan, L., Van Den End, J., W., 2013. Bank liquidity, the maturity ladder, and regulation. Journal of Banking and Finance 37(10), 3930-3950.

De Haas, R., Van Horen, N., 2013. Running for the exit? International bank lending during a financial crisis. Review of Financial Studies 26, 244-285. 
De Jonghe, O., Öztekin, Ö., 2015. Bank capital management: International evidence. Journal of Financial Intermediation 24(2), 154-177.

Dermine, J., 2015. Basel III leverage ratio requirement and the probability of bank runs. Journal of Banking and Finance 53, 266-277

DeYoung, R., Distinguin, I., Tarazi, A., 2018. The joint regulation of bank liquidity and bank capital. Journal of Financial Intermediation 34, 32-46.

DeYoung, R., Jang, K., Y., 2016. Do banks actively manage their liquidity? Journal of Banking and Finance 66, 143-161.

Distinguin, I., Roulet, C., Tarazi, A., 2013. Bank regulatory capital and liquidity: evidence from U.S. and European publicly traded banks. Journal of Banking and Finance 37 (9), 3295331.

Dombret, A., Foos, D., Pliszka, K., Shulz, A., 2018. What are the real effects of financial market liquidity? Evidence on bank lending from the Euro area. Deutsche Bundesbank Discussion Paper No. 34/2018.

Flannery, M., J., Ranjan, K., P., 2006. Partial adjustment toward target capital structures. Journal of Financial Economics 79 (3), 469-506.

Fonseca, A., R., González, F., 2009. How bank capital buffers vary across countries: The influence of cost of deposits, market power and bank regulation. Journal of banking and Finance 34(4), 892-902.

Gatev, E., Strahan, P., 2006. Banks' advantage in hedging liquidity risk: Theory and evidence from the commercial paper market. Journal of Finance 61, 867-892.

Gropp, R., Heider, F., 2010. The Determinants of Bank Capital Structure. Review of Finance 14(4), 587-622.

Hong, H., Huang, J., Wu, D., 2014. The information content of Basel III liquidity risk measures. Journal of Financial Stability 15, 91-111.

Ivashina, V., Scharfstein, D., 2008. Bank lending during the financial crisis of 2008. Journal of Financial Economics 97(3), 319-338.

Judson, R., A., Owen, A., L., 1999. Estimating dynamic panel data models: a guide for macroeconomists. Economics Letters 65 (1), 9-15.

Kim, D., Sohn, W., 2017. The effect of bank capital on lending: Does liquidity matter? Journal of Banking \& Finance 77, 95-107.

Kiviet, J., F., 1995. On Bias, Inconsistency, and Efficiency of Various Estimators in Dynamic Panel Data Models. Journal of Econometrics 68(1), 53-78. 
Lemmon, M., L., Roberts, R., M., Zender, J., F., 2008. Back to the beginning: Persistence and the cross- section of corporate capital structure. Journal of Finance 63(4), 1575-1608.

Lepetit, L., Saghi-Zedek, N., Tarazi, A., 2015. Excess Control Rights, Bank Capital Structure Adjustments, and Lending. Journal of Financial Economics 115(3), 574-591.

Loutskina, E., 2011. The role of securitization in bank liquidity and funding management. Journal of Financial Economics 100(3), 98-110.

Memmel, C., Raupach, P., 2010. How do banks adjust their capital ratios? Journal of Financial Intermediation 19(4), 509-528.

Myers, S., C., Majluf, N., S., 1984. Corporate financing and investment decisions when firms have information that investors do not have. Journal of Financial Economics 13(2), 187222.

Nickell, S., 1981. Biases in Dynamic Models with Fixed Effects. Econometrica 49, 13991416.

Öztekin, Ö., Flannery, M., J., 2012. Institutional determinants of capital structure adjustment speeds. Journal of Financial Economics 103(1), 88-112.

Peek, J., Rosengren, E., 1997. The international transmission of financial shocks: the case of Japan. Am. Econ. Rev. 87 (1997), 495-505.

Pennacchi, G., 2006. Deposit insurance, bank regulation, and financial system risks. Journal of Monetary Economics 53(1), 1-30.

Puri, M., Rocholl, J., Steffen, S., 2011. Global retail lending in the aftermath of the U.S. financial crisis distinguishing between supply and demand effects. Journal of Financial Economics 100(3), 556-578.

Ramos, A., 1996. Deposit insurance, bank capital structure and demand for liquidity. Federal Reserve Bank of Chicago working paper.

Rodríguez-Moreno M., Peña, J., I., 2013. Systemic risk measures: the simpler the better? Journal of Banking and Finance 37 (6), 1817-1831.

Roodman, D., 2006. How to do xtabond2: An introduction to difference and system GMM in Stata. Center for Global Development working paper number 103.

Roodman, D., 2009. How to do xtabond2: An introduction to difference and system GMM in Stata. Stata Journal 9, 86-136.

Schnabl, P., 2012. The international transmission of bank liquidity shocks: evidence from an emerging market. Journal of Finance 67 (3), 897-932.

Shim, J., 2012. Bank capital buffer and portfolio risk: the influence of business cycle and revenue diversification. Journal of Banking and Finance 37 (3), 761-772. 
Wu, D., Hong, H., 2012. Liquidity Risk, Market Valuation, and Bank Failures. Available at SSRN https://ssrn.com/abstract=2177583. 
Table 1: Definition of variables and descriptive statistics

\begin{tabular}{|c|c|c|c|c|c|c|}
\hline Variables & definitions & Obs & Mean & Std. Dev. & Min & Max \\
\hline \multicolumn{7}{|l|}{ Dependent variables } \\
\hline $\operatorname{tcr}(\%)$ & total capital ratio & 438,608 & 18.05 & 10.20 & 9.84 & 67.25 \\
\hline rwa $(\%)$ & risk weighted assets as a percent of total assets & 434,251 & 67.71 & 13.97 & 26 & 98.67 \\
\hline$\Delta$ rwa & quarterly change in risk weighted assets to total assets ratio & 424,181 & 0.09 & 4.01 & -72.67 & 72.67 \\
\hline loan_a $(\%)$ & total loans to total assets ratio & 434,257 & 62.49 & 16.17 & 19.30 & 88.14 \\
\hline$\Delta$ loan & quarterly change in total loans to total assets ratio & 424,224 & 0.11 & 3.83 & -68.84 & 68.84 \\
\hline$\Delta \operatorname{asset}(\%)$ & quarterly change in total assets divided by total assets & 428,546 & 1.85 & 5.42 & -11.88 & 26.13 \\
\hline dividend $(\%)$ & dividend to total assets ratio & 265,268 & 0.25 & 0.62 & 0 & 3.44 \\
\hline Tier one $(\%)$ & Tier one capital ratio & 438,410 & 16.79 & 10.06 & 7.95 & 64.68 \\
\hline$\Delta$ tier & quarterly change in Tier 1 ratio & 428,309 & -0.15 & 2.18 & -56.40 & 56.73 \\
\hline \multicolumn{7}{|c|}{ Market liquidity shortages proxies } \\
\hline TED spread $(\%)$ & $\begin{array}{l}\text { the difference between the three-month London Interbank Offered Rate (LIBOR) and the three-month } \\
\text { Treasury bills rate }\end{array}$ & 438,608 & 0.47 & 0.42 & 0.15 & 2.45 \\
\hline MLS_ted & dummy equal to one if the TED spread is higher than its $75^{\text {th }}$ percentile or zero otherwise** & 438,608 & 0.25 & 0.43 & 0 & 1 \\
\hline commercial paper spread (\%) & $\begin{array}{l}\text { the spread between the three-month commercial paper rate for highly rated (AA) non-financial } \\
\text { borrowers and the three-month Treasury bills rate. }\end{array}$ & 438,608 & 0.33 & 0.39 & 0.07 & 2.28 \\
\hline MLS_cp & $\begin{array}{l}\text { dummy equal to one if the commercial paper spread is higher than its } 75^{\text {th }} \text { percentile or zero } \\
\text { otherwise** }\end{array}$ & 438,608 & 0.27 & 0.44 & 0 & 1 \\
\hline \multicolumn{7}{|c|}{ Extent on market liquidity proxies } \\
\hline NSFR $(\%)$ & Net Stable Funding Ratio (see Appendix K) & 277,247 & 84.39 & 50.07 & 9.16 & 224.59 \\
\hline Z_nsfr & dummy equal to one if the NSFR $<100 \%$ or zero otherwise** & 277,247 & 0.63 & 0.48 & 0 & 1 \\
\hline $\operatorname{rwf}(\%)$ & $\begin{array}{l}\text { reliance on wholesale funding, it depicts the portion of a bank's total funds that are from wholesale } \\
\text { sources. (total borrowings }+ \text { brokered deposits) } / \text { (total borrowings }+ \text { total deposits). }\end{array}$ & 431,331 & 8.23 & 10 & 0 & 40.62 \\
\hline Z_rwf & dummy equal to one if rwf is higher than its $75^{\text {th }}$ percentile or zero otherwise & 431,331 & 0.25 & 0.43 & 0 & 1 \\
\hline LTCD $(\%)$ & loans to core deposits ratio & 429,942 & 78.44 & 32.42 & 7.03 & 238.75 \\
\hline
\end{tabular}


purchased under agreements to resell, total securities, and total trading account assets less the value of total pledged securities

Variables for bank's capital position

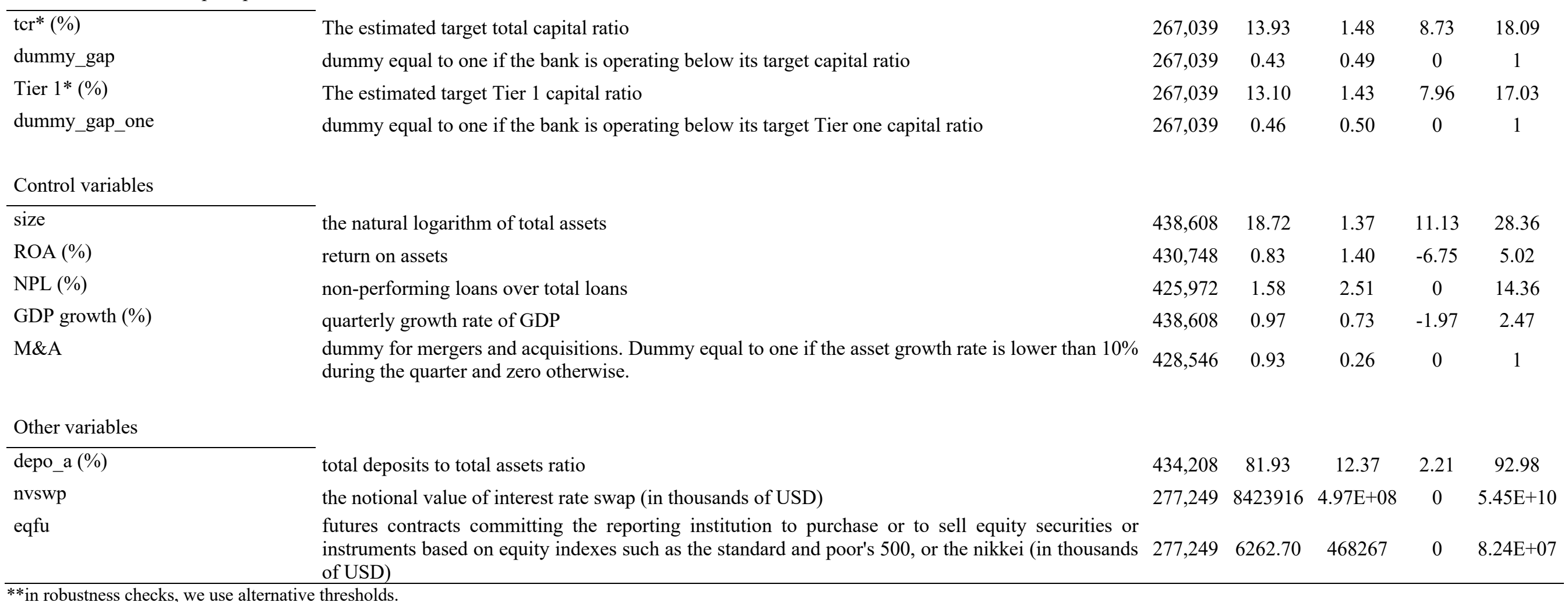


TABLE 2: Impact of market liquidity shortages according to bank liquidity level

This table displays the impact of market liquidity shortages on the change in total capital ratio ( $\triangle \mathrm{TCR}$ ), on the change in asset part of risk weighted assets ( $\triangle \mathrm{RWA}$ ), on the change in asset part of total loans ( $\triangle \mathrm{LOAN}$ ), on the change in total assets ( $\triangle \mathrm{ASSET}$ ) and on dividend to total assets ratio (DIVIDEND) according to whether or not the bank is more reliant on market liquidity. MLS $\mathrm{S}_{\mathrm{t}-1}$ is a dummy variable that is equal to one if

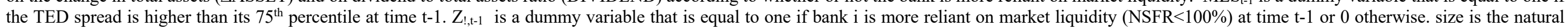

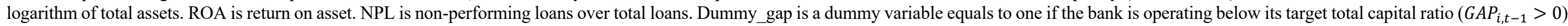

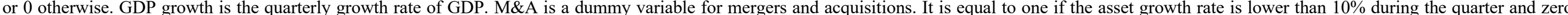

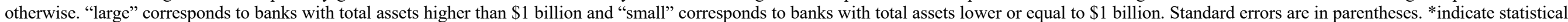
significance at the $10 \%$ level. **indicate statistical significance at the $5 \%$ level. $* * *$ indicate statistical significance at the $1 \%$ level.

\begin{tabular}{|c|c|c|c|c|c|c|c|c|c|c|}
\hline & \multicolumn{2}{|c|}{$\triangle \mathrm{TCR}$} & \multicolumn{2}{|c|}{$\Delta \mathrm{RWA}$} & \multicolumn{2}{|c|}{$\triangle \mathrm{LOAN}$} & \multicolumn{2}{|c|}{$\triangle \mathrm{ASSET}$} & \multicolumn{2}{|c|}{ DIVIDEND } \\
\hline & LARGE & SMALL & LARGE & SMALL & LARGE & SMALL & LARGE & SMALL & LARGE & SMALL \\
\hline \multirow[t]{2}{*}{$M L S_{t-1}\left(\varphi_{1}\right)$} & -0.578 & $0.263^{* * *}$ & $1.501^{*}$ & $-0.422^{* * *}$ & -0.159 & $-0.456^{* * *}$ & 0.187 & $-0.430^{* *}$ & 0.0575 & $0.0513^{* *}$ \\
\hline & $(0.580)$ & $(0.0973)$ & $(0.793)$ & $(0.157)$ & $(0.818)$ & $(0.152)$ & $(0.683)$ & $(0.172)$ & $(0.0570)$ & $(0.0259)$ \\
\hline \multirow[t]{2}{*}{$Z_{i, t-1}\left(\varphi_{2}\right)$} & 0.103 & $0.0685^{* * *}$ & -0.137 & $-0.142^{* * *}$ & $-0.530^{* *}$ & $-0.270^{* * *}$ & 0.0816 & 0.0198 & -0.00106 & 0.00587 \\
\hline & $(0.166)$ & $(0.0137)$ & $(0.212)$ & $(0.0238)$ & $(0.259)$ & $(0.0244)$ & $(0.206)$ & $(0.0255)$ & $(0.0210)$ & $(0.00456)$ \\
\hline \multirow[t]{2}{*}{$d u m m y_{-} g a p_{i, t-1}\left(\varphi_{3}\right)$} & $0.597^{* * *}$ & $0.414^{* * *}$ & $-0.860^{* * *}$ & $-0.931^{* * *}$ & $-0.380^{* *}$ & $-0.475^{* * *}$ & $0.456^{* * *}$ & $0.193^{* * *}$ & $-0.0502^{* * *}$ & $-0.0144^{* * *}$ \\
\hline & $(0.0965)$ & $(0.0154)$ & $(0.128)$ & $(0.0308)$ & $(0.168)$ & $(0.0276)$ & $(0.139)$ & $(0.0290)$ & $(0.0127)$ & $(0.00448)$ \\
\hline \multirow[t]{2}{*}{$Z_{i, t-1} * M L S_{t-1}\left(\varphi_{4}\right)$} & 0.191 & $0.173^{* * *}$ & -0.495 & $-0.290^{* * *}$ & -0.0516 & $-0.234^{* * *}$ & -0.142 & 0.0345 & 0.0110 & -0.00767 \\
\hline & $(0.155)$ & $(0.0244)$ & $(0.364)$ & $(0.0427)$ & $(0.393)$ & $(0.0397)$ & $(0.344)$ & $(0.0394)$ & $(0.0340)$ & $(0.00666)$ \\
\hline \multirow[t]{2}{*}{ Size $_{i, t-1}$} & 0.105 & $1.066^{* * *}$ & 0.286 & $-0.961^{* * *}$ & -0.412 & $-1.324^{* * *}$ & $-2.360^{* * *}$ & $-2.310^{* * *}$ & 0.0164 & $-0.0945^{* * *}$ \\
\hline & $(0.273)$ & $(0.0552)$ & $(0.370)$ & $(0.0675)$ & $(0.325)$ & $(0.0760)$ & $(0.247)$ & $(0.0853)$ & $(0.0175)$ & $(0.0120)$ \\
\hline \multirow[t]{2}{*}{$\mathrm{ROA}_{i, t-1}$} & $0.221^{* * *}$ & $0.379^{* * *}$ & -0.0235 & $-0.204^{* * *}$ & $-0.137^{* *}$ & $-0.326^{* * *}$ & $0.273^{* * *}$ & $0.184^{* * *}$ & $0.0111^{* *}$ & $0.00441^{* *}$ \\
\hline & $(0.0360)$ & $(0.0115)$ & $(0.0464)$ & $(0.0166)$ & $(0.0533)$ & $(0.0172)$ & $(0.0490)$ & $(0.0137)$ & $(0.00459)$ & $(0.00185)$ \\
\hline \multirow[t]{2}{*}{$\mathrm{NPL}_{i, t-1}$} & $0.0532^{* *}$ & $0.0924^{* * *}$ & $-0.102^{* * *}$ & $-0.144^{* * *}$ & $-0.138^{* * *}$ & $-0.196^{* * *}$ & $-0.243^{* * *}$ & $-0.296^{* * *}$ & -0.00259 & 0.000494 \\
\hline & $(0.0213)$ & $(0.00384)$ & $(0.0264)$ & $(0.00611)$ & $(0.0330)$ & $(0.00660)$ & $(0.0394)$ & $(0.00745)$ & $(0.00554)$ & $(0.000958)$ \\
\hline GDP growth $_{t-1}$ & $(0.307)$ & $(0.0544)$ & $(0.297)$ & $(0.0933)$ & $(0.372)$ & $(0.0915)$ & $(0.270)$ & $(0.0989)$ & $(0.0192)$ & $(0.0112)$ \\
\hline \multirow[t]{2}{*}{$M \& A_{i, t-1}$} & $0.904^{* * *}$ & $1.407^{* * *}$ & $3.036^{* * *}$ & $3.245^{* * *}$ & $2.175^{* * *}$ & $3.611^{* * *}$ & $-15.36^{* * *}$ & $-13.11^{* * *}$ & 0.0183 & $0.0179^{* * *}$ \\
\hline & $(0.111)$ & $(0.0392)$ & $(0.210)$ & $(0.0676)$ & $(0.245)$ & $(0.0777)$ & $(0.267)$ & $(0.0805)$ & $(0.0160)$ & $(0.00658)$ \\
\hline Banks fixed effect & yes & yes & yes & yes & yes & yes & yes & yes & yes & yes \\
\hline time fixed effect & yes & yes & yes & yes & yes & yes & yes & yes & yes & yes \\
\hline$\varphi_{1}+\varphi_{4}$ & -0.387 & 0.435 & 1.006 & -0.711 & -0.211 & -0.690 & 0.0457 & -0.396 & 0.0685 & 0.0437 \\
\hline Wald test $p$ value & 0.493 & 0.000 & 0.147 & 0.000 & 0.766 & 0.000 & 0.939 & 0.021 & 0.0918 & 0.0846 \\
\hline r2 & 0.0770 & 0.210 & 0.116 & 0.0895 & 0.0760 & 0.130 & 0.625 & 0.542 & 0.415 & 0.525 \\
\hline $\mathrm{N}$ & 17408 & 249459 & 17181 & 248520 & 17181 & 248527 & 17408 & 249459 & 17082 & 237443 \\
\hline
\end{tabular}


TABLE 3: Impact of market liquidity shortages according to gap between actual and target capital

This table displays the impact of market liquidity shortages on the change in total capital ratio ( $\triangle \mathrm{TCR})$, on the change in asset part of risk weighted assets ( $\triangle \mathrm{RWA})$, on the change in asset part of total loans ( $\triangle \mathrm{LOAN}$ ), on the change in total assets ( $\triangle \mathrm{ASSET}$ ) and on dividend to total assets ratio (DIVIDEND) according to whether or not the bank is operating below its target total capital ratio. MLS $\mathrm{S}_{\mathrm{t}-1}$ is a dummy variable that is equal

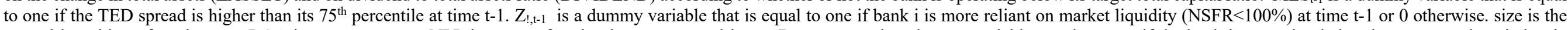

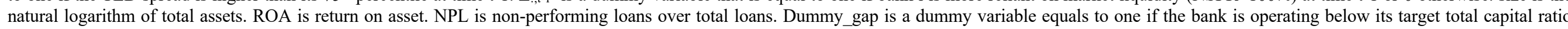

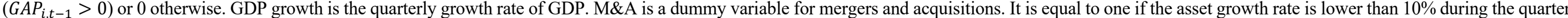

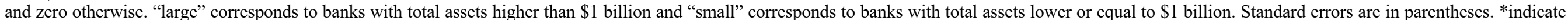
statistical significance at the $10 \%$ level. **indicate statistical significance at the $5 \%$ level. ***indicate statistical significance at the $1 \%$ level.

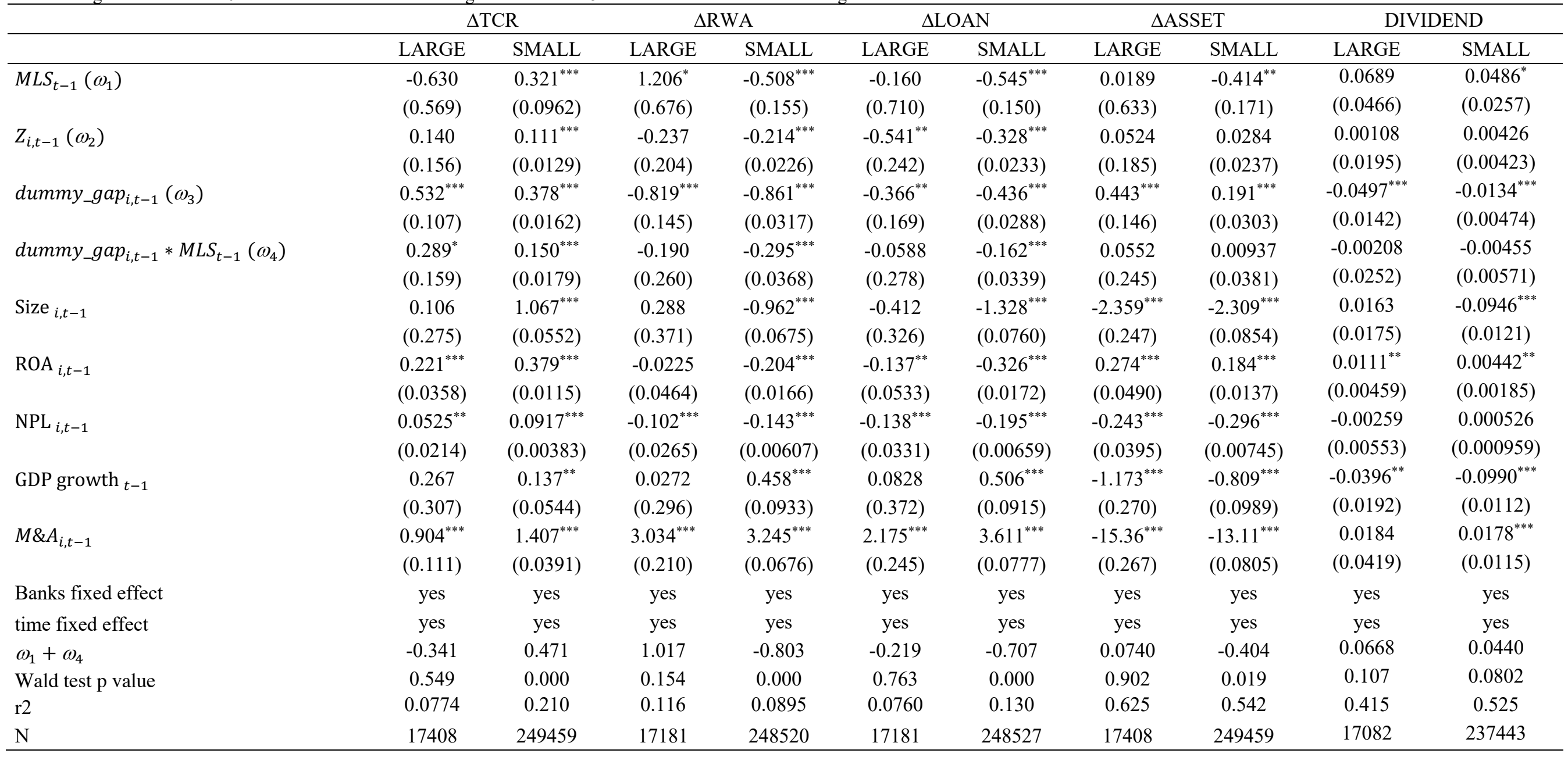


TABLE 4: Impact of market liquidity shortages according to bank liquidity level during non-crisis period

This table displays during non-crisis period, the impact of market liquidity shortages on the change in total capital ratio $(\triangle \mathrm{TCR})$, on the change in asset part of risk weighted assets ( $\triangle \mathrm{RWA}$ ), on the change in asset part of total loans ( $\triangle \mathrm{LOAN}$ ), on the change in total assets ( $\triangle \mathrm{ASSET}$ ) and on dividend to total assets ratio (DIVIDEND) according to whether or not the bank is more reliant on market liquidity. We exclude the crisis period from our investigation period. MLS $\mathrm{t}_{-1}$ is a dummy variable that is equal to one if the TED spread is higher than its $75^{\text {th }}$ percentile at time $t-1$ throughout the entire sample. $Z_{! t-1-1}$ is a dummy variable that is equal to one if bank $i$ is more reliant on market liquidity (NSFR $<100 \%$ ) at time $t-1$ or 0 otherwise. size is the natural logarithm of total assets. ROA is return on asset. NPL is non-performing loans over total loans. Dummy gap is a dummy variable equals to one if the bank is operating below its target total capital ratio $\left(G A P_{i, t-1}>0\right)$ or 0 otherwise. GDP growth is the quarterly growth rate of GDP. M\&A is a dummy variable for mergers and acquisitions. It is equal to one if the asset growth rate is lower than $10 \%$ during the quarter and zero otherwise. "large" corresponds to banks with total assets higher than $\$ 1$ billion and "small" corresponds to banks with total assets lower or equal to $\$ 1$ billion. Standard errors are in parentheses. *indicate statistical significance at the $10 \%$ level. **indicate statistical significance at the $5 \%$ level. $* * *$ indicate statistical significance at the $1 \%$ level.

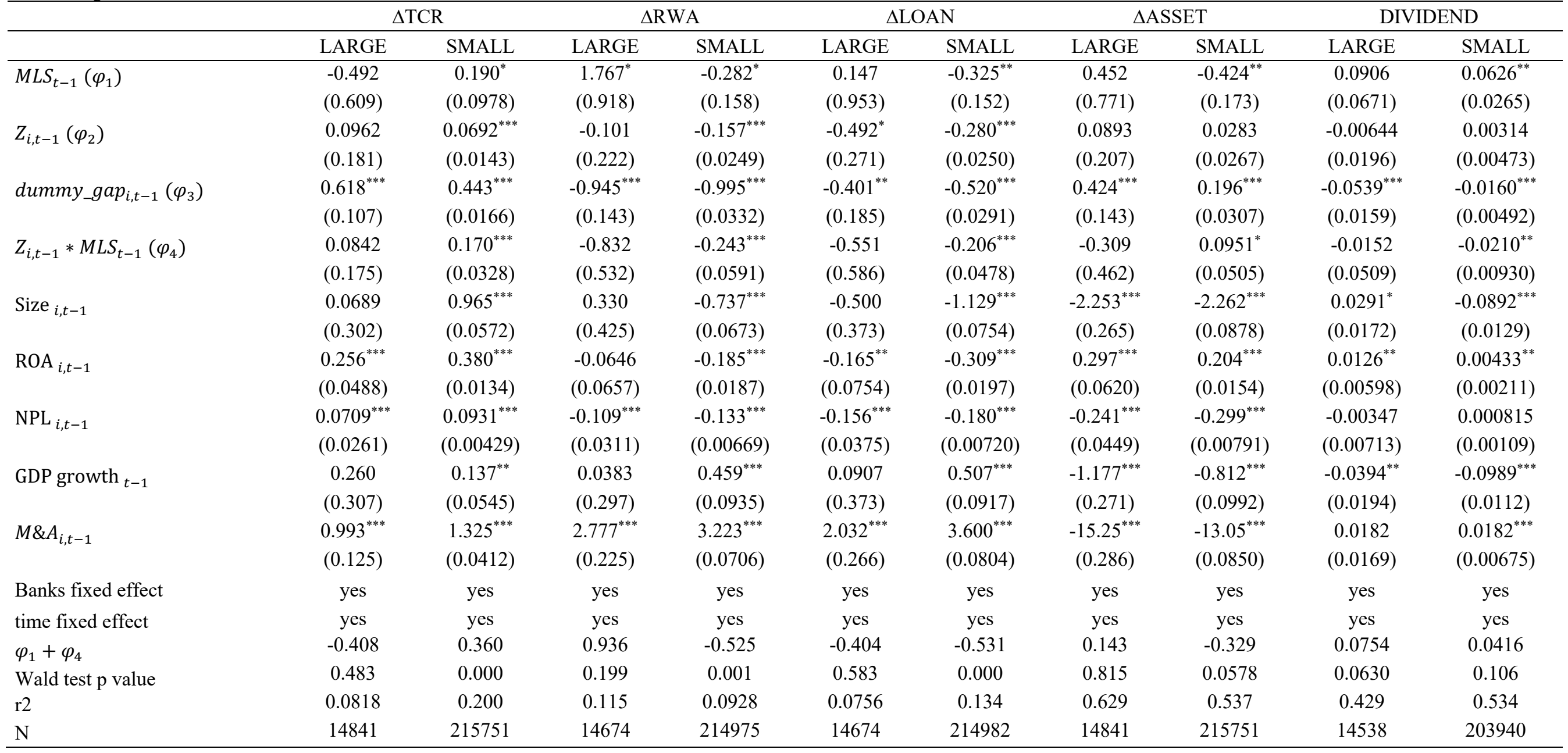


TABLE 5: Impact of market liquidity shortages according to gap between actual and target capital during non-crisis period

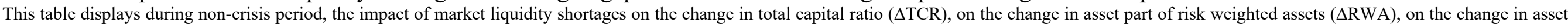

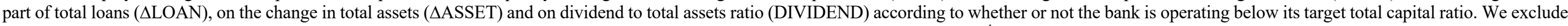

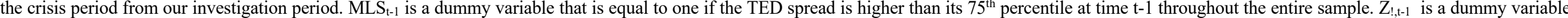

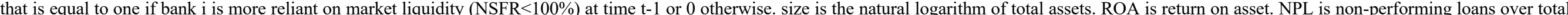

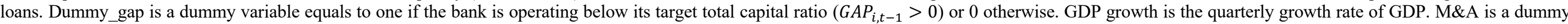

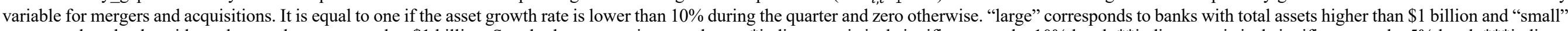

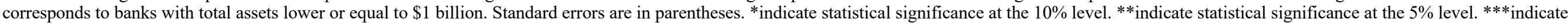
statistical significance at the $1 \%$ level.

\begin{tabular}{|c|c|c|c|c|c|c|c|c|c|c|}
\hline & \multicolumn{2}{|c|}{$\Delta \mathrm{TCR}$} & \multicolumn{2}{|c|}{$\Delta \mathrm{RWA}$} & \multicolumn{2}{|c|}{$\triangle \mathrm{LOAN}$} & \multicolumn{2}{|c|}{$\triangle \mathrm{ASSET}$} & \multicolumn{2}{|c|}{ DIVIDEND } \\
\hline & LARGE & SMALL & LARGE & SMALL & LARGE & SMALL & LARGE & SMALL & LARGE & SMALL \\
\hline \multirow{2}{*}{$M L S_{t-1}\left(\omega_{1}\right)$} & -0.638 & $0.228^{* *}$ & $1.532^{* *}$ & $-0.330^{* *}$ & -0.178 & $-0.400^{* * *}$ & 0.298 & $-0.367^{* *}$ & $0.147^{* *}$ & $0.0534^{* *}$ \\
\hline & $(0.564)$ & $(0.0962)$ & $(0.720)$ & $(0.155)$ & $(0.762)$ & $(0.150)$ & $(0.670)$ & $(0.171)$ & $(0.0637)$ & $(0.0260)$ \\
\hline$Z_{i, t-1}\left(\omega_{2}\right)$ & $(0.176)$ & (0.0139) & $(0.220)$ & $(0.0243)$ & $(0.258)$ & $(0.0241)$ & $(0.199)$ & $(0.0258)$ & $(0.0194)$ & $(0.00460)$ \\
\hline \multirow[t]{2}{*}{$d u m m y \_g a p_{i, t-1}\left(\omega_{3}\right)$} & $0.584^{* * *}$ & $0.410^{* * *}$ & $-0.869^{* * *}$ & $-0.944^{* * *}$ & $-0.377^{* *}$ & $-0.499^{* * *}$ & $0.442^{* * *}$ & $0.200^{* * *}$ & $-0.0438^{* * *}$ & $-0.0156^{* * *}$ \\
\hline & $(0.113)$ & $(0.0172)$ & $(0.155)$ & $(0.0335)$ & $(0.180)$ & $(0.0298)$ & $(0.148)$ & $(0.0315)$ & $(0.0161)$ & $(0.00504)$ \\
\hline$d u m m y_{-} g a p_{i, t-1} * M L S_{t-1}\left(\omega_{4}\right)$ & $(0.293)$ & $(0.0258)$ & $(0.470)$ & $(0.0561)$ & $(0.463)$ & $(0.0451)$ & $(0.340)$ & $(0.0507)$ & $(0.0425)$ & $(0.00802)$ \\
\hline \multirow{2}{*}{ Size $_{i, t-1}$} & 0.0720 & $0.970^{* * *}$ & 0.326 & $-0.745^{* * *}$ & -0.499 & $-1.133^{* * *}$ & $-2.254^{* * *}$ & $-2.262^{* * *}$ & $0.0283^{*}$ & $-0.0894^{* * *}$ \\
\hline & $(0.305)$ & $(0.0574)$ & $(0.427)$ & $(0.0673)$ & $(0.374)$ & $(0.0756)$ & $(0.266)$ & $(0.0878)$ & $(0.0171)$ & $(0.0129)$ \\
\hline \multirow{2}{*}{$\mathrm{ROA}_{i, t-1}$} & $0.256^{* * *}$ & $0.380^{* * *}$ & -0.0638 & $-0.185^{* * *}$ & $-0.165^{* *}$ & $-0.309^{* * *}$ & $0.298^{* * *}$ & $0.204^{* * *}$ & $0.0126^{* *}$ & $0.00435^{* *}$ \\
\hline & $(0.0488)$ & $(0.0134)$ & $(0.0655)$ & $(0.0187)$ & $(0.0753)$ & $(0.0197)$ & $(0.0620)$ & $(0.0154)$ & (0.00599) & $(0.00211)$ \\
\hline \multirow{2}{*}{$\mathrm{NPL}_{i, t-1}$} & $0.0709^{* * *}$ & $0.0929^{* * *}$ & $-0.109^{* * *}$ & $-0.133^{* * *}$ & $-0.155^{* * *}$ & $-0.179^{* * *}$ & $-0.240^{* * *}$ & $-0.299^{* * *}$ & -0.00338 & 0.000873 \\
\hline & $(0.0261)$ & $(0.00428)$ & $(0.0312)$ & $(0.00668)$ & $(0.0376)$ & $(0.00720)$ & $(0.0449)$ & $(0.00790)$ & $(0.00712)$ & (0.00109) \\
\hline GDP growth $_{t-1}$ & $(0.307)$ & $(0.0545)$ & $(0.297)$ & $(0.0935)$ & $(0.372)$ & $(0.0917)$ & $(0.271)$ & $(0.0992)$ & $(0.0194)$ & $(0.0112)$ \\
\hline \multirow[t]{2}{*}{$M \& A_{i, t-1}$} & $0.994^{* * *}$ & $1.324^{* * *}$ & $2.770^{* * *}$ & $3.224^{* * *}$ & $2.028^{* * *}$ & $3.600^{* * *}$ & $-15.25^{* * *}$ & $-13.05^{* * *}$ & 0.0179 & $0.0181^{* * *}$ \\
\hline & $(0.125)$ & $(0.0411)$ & $(0.226)$ & $(0.0706)$ & $(0.266)$ & $(0.0804)$ & $(0.286)$ & $(0.0850)$ & $(0.0170)$ & $(0.00675)$ \\
\hline Banks fixed effect & yes & yes & yes & yes & yes & yes & yes & yes & yes & yes \\
\hline time fixed effect & yes & yes & yes & yes & yes & yes & yes & yes & yes & yes \\
\hline$\omega_{1}+\omega_{4}$ & -0.348 & 0.484 & 0.873 & -0.730 & -0.392 & -0.562 & 0.141 & -0.402 & 0.0536 & 0.0480 \\
\hline Wald test $\mathrm{p}$ value & 0.566 & 0.000 & 0.258 & 0.000 & 0.610 & 0.000 & 0.820 & 0.0235 & 0.149 & 0.0614 \\
\hline $\mathrm{r} 2$ & 0.0820 & 0.200 & 0.115 & 0.0929 & 0.0755 & 0.134 & 0.629 & 0.537 & 0.430 & 0.534 \\
\hline $\mathrm{N}$ & 14841 & 215751 & 14674 & 214975 & 14674 & 214982 & 14841 & 215751 & 14538 & 203940 \\
\hline
\end{tabular}


Graph 1: The evolution of TED spread and commercial paper spread from 2000 to 2014 (average quarterly data). Source: Federal Reserve Bank of St Louis website

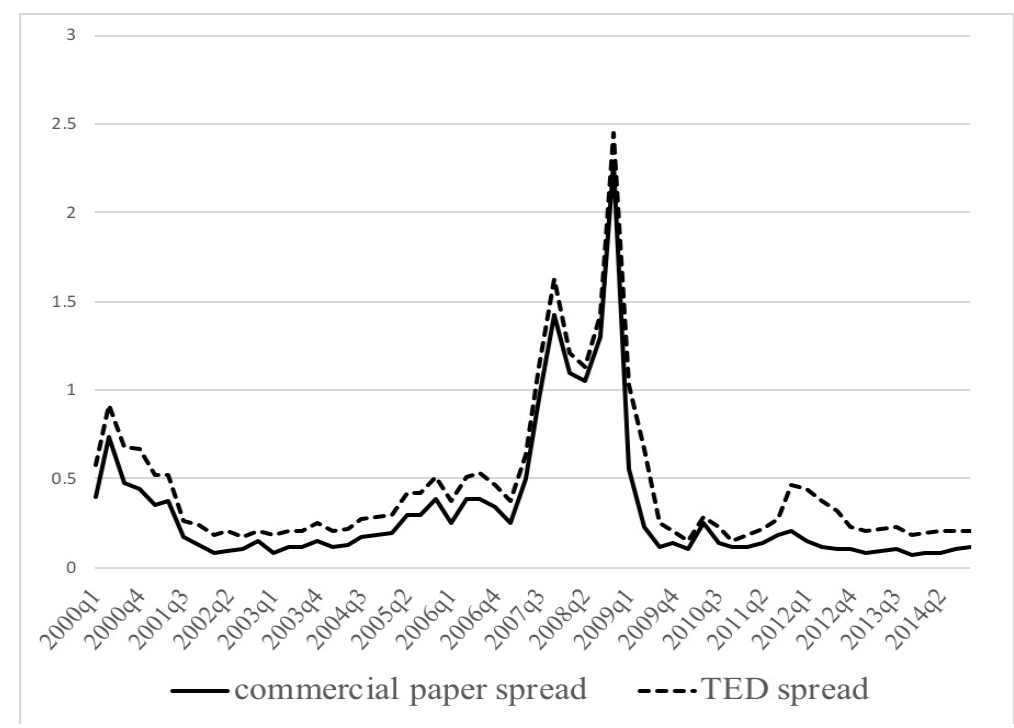

Graph 2: The evolution of TED spread and commercial paper spread from 2000 to 2014 (average quarterly data) while excluding the global financial crisis period (2007q3 to 2009q2). Source: Federal Reserve Bank of St Louis website

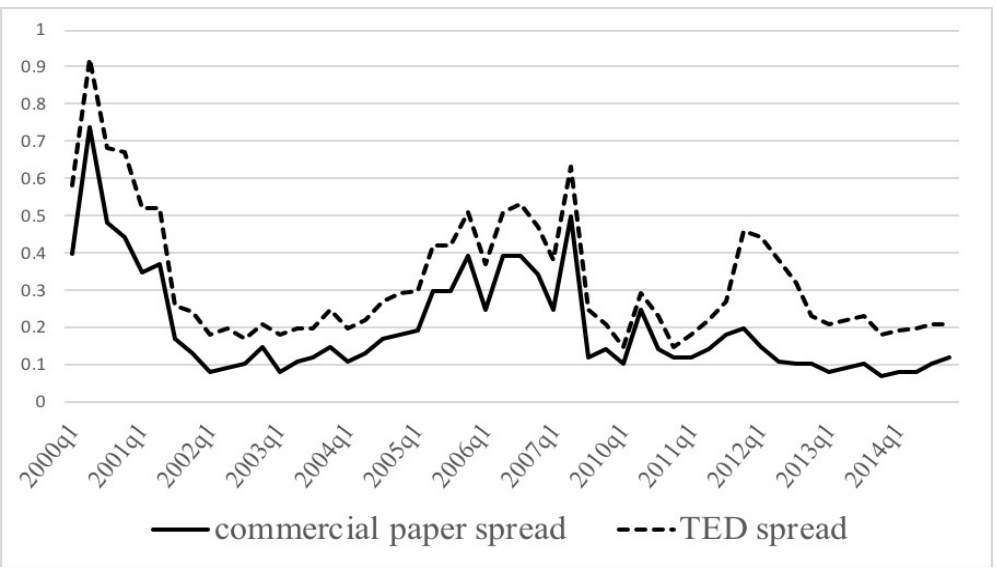




\section{APPENDIX A}

\section{Estimation of target capital ratios}

This table displays the results of the estimation of equation (3) using fixed effect methodology and allowing computing the target capital ratios. MLS is a dummy variable that is equal to one if the TED spread is higher than its $75^{\text {th }}$ percentile at time t- 1 throughout the whole sample. NSFR is Net Stable Funding Ratio. size is the natural logarithm of total assets. ROA is return on assets, NPL is the ratio of non-performing loans to total loans. M\&A is a dummy variable for mergers and acquisitions. Standard errors are in parentheses. *indicate statistical significance at the $10 \%$ level. **indicate statistical significance at the $5 \%$ level. ***indicate statistical significance at the $1 \%$ level. All independent variables are lagged one quarter.

\begin{tabular}{|c|c|c|}
\hline & TCR & TIER ONE \\
\hline \multirow[t]{2}{*}{ Lag dependent variable } & $0.826^{* * *}$ & $0.831^{* * *}$ \\
\hline & $(0.00380)$ & $(0.00369)$ \\
\hline \multirow[t]{2}{*}{ NSFR } & $0.000615^{* *}$ & $0.000583^{* *}$ \\
\hline & $(0.000252)$ & $(0.000245)$ \\
\hline \multirow[t]{2}{*}{ size } & $0.106^{* * *}$ & $0.0956^{* * *}$ \\
\hline & $(0.0313)$ & $(0.0306)$ \\
\hline \multirow[t]{2}{*}{$\mathrm{ROA}$} & $0.122^{* * *}$ & $0.117^{* * *}$ \\
\hline & $(0.00951)$ & $(0.00922)$ \\
\hline \multirow[t]{2}{*}{ NPL } & $0.0657^{* * *}$ & $0.0599^{* * *}$ \\
\hline & $(0.00465)$ & $(0.00456)$ \\
\hline \multirow[t]{2}{*}{ GDP growth rate } & $0.0163^{* * *}$ & $0.0213^{* * *}$ \\
\hline & $(0.00577)$ & $(0.00566)$ \\
\hline \multirow[t]{2}{*}{$M \& A$} & $0.225^{* * *}$ & $0.224^{* * *}$ \\
\hline & $(0.0241)$ & $(0.0237)$ \\
\hline \multirow[t]{2}{*}{ MLS } & $-0.130^{* * *}$ & $-0.129^{* * *}$ \\
\hline & $(0.0105)$ & $(0.0103)$ \\
\hline \multirow[t]{2}{*}{ constant } & 0.477 & 0.393 \\
\hline & $(0.598)$ & $(0.584)$ \\
\hline r2 & 0.825 & 0.831 \\
\hline $\mathrm{N}$ & 267039 & 267036 \\
\hline
\end{tabular}




\section{APPENDIX B:}

TABLE 1B: Impact of severe market liquidity shortages $\left(90^{\text {th }}\right.$ percentile) according to bank liquidity level

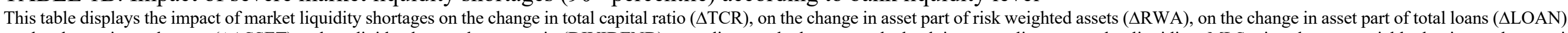

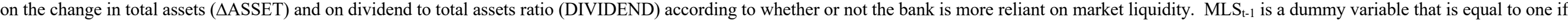

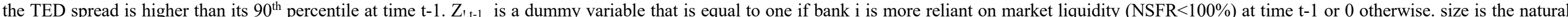

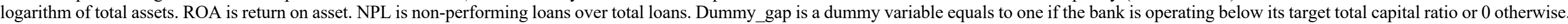

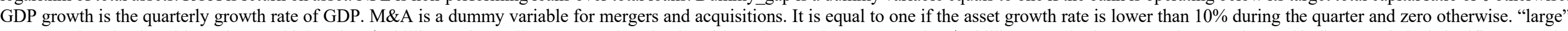

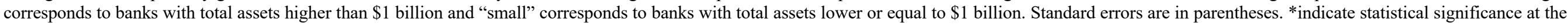
$10 \%$ level. **indicate statistical significance at the $5 \%$ level. ***indicate statistical significance at the $1 \%$ level.

\begin{tabular}{|c|c|c|c|c|c|c|c|c|c|c|}
\hline & \multicolumn{2}{|c|}{$\triangle \mathrm{TCR}$} & \multicolumn{2}{|c|}{$\Delta \mathrm{RWA}$} & \multicolumn{2}{|c|}{$\triangle \mathrm{LOAN}$} & \multicolumn{2}{|c|}{$\triangle \mathrm{ASSET}$} & \multicolumn{2}{|c|}{ DIVIDEND } \\
\hline & LARGE & SMALL & LARGE & SMALL & LARGE & SMALL & LARGE & SMALL & LARGE & SMALL \\
\hline \multirow[t]{2}{*}{$M L S_{t-1}\left(\varphi_{1}\right)$} & 0.150 & $0.984^{* * *}$ & 0.404 & $-0.636^{* * *}$ & $-1.892^{* *}$ & $-1.109^{* * *}$ & $-3.720^{* * *}$ & $-2.065^{* * *}$ & -0.0839 & $-0.247^{* * *}$ \\
\hline & $(0.600)$ & $(0.0970)$ & $(0.777)$ & $(0.165)$ & $(0.783)$ & $(0.166)$ & $(0.690)$ & $(0.170)$ & $(0.0770)$ & $(0.0270)$ \\
\hline \multirow[t]{2}{*}{$Z_{i, t-1}\left(\varphi_{2}\right)$} & 0.120 & $0.0973^{* * *}$ & -0.237 & $-0.190^{* * *}$ & $-0.585^{* *}$ & $-0.310^{* * *}$ & 0.0419 & 0.0353 & -0.00270 & 0.00485 \\
\hline & $(0.157)$ & $(0.0133)$ & $(0.209)$ & $(0.0231)$ & $(0.243)$ & $(0.0234)$ & $(0.192)$ & $(0.0243)$ & $(0.0203)$ & $(0.00435)$ \\
\hline \multirow[t]{2}{*}{$d u m m y_{-} g a p_{i, t-1}\left(\varphi_{3}\right)$} & $0.598^{* * *}$ & $0.414^{* * *}$ & $-0.862^{* * *}$ & $-0.931^{* * *}$ & $-0.379^{* *}$ & $-0.475^{* * *}$ & $0.455^{* * *}$ & $0.193^{* * *}$ & $-0.0502^{* * *}$ & $-0.0144^{* * *}$ \\
\hline & $(0.0965)$ & $(0.0154)$ & $(0.129)$ & $(0.0308)$ & $(0.168)$ & $(0.0276)$ & $(0.139)$ & $(0.0290)$ & $(0.0127)$ & $(0.00448)$ \\
\hline \multirow{2}{*}{$Z_{i, t-1} * M L S_{t-1}\left(\varphi_{4}\right)$} & 0.313 & $0.156^{* * *}$ & -0.00848 & $-0.268^{* * *}$ & 0.620 & $-0.203^{* * *}$ & 0.150 & -0.0760 & 0.0512 & -0.00620 \\
\hline & $(0.281)$ & $(0.0383)$ & $(0.401)$ & $(0.0647)$ & $(0.426)$ & $(0.0691)$ & $(0.406)$ & $(0.0599)$ & $(0.0502)$ & $(0.00911)$ \\
\hline \multirow{2}{*}{ Size $_{i, t-1}$} & 0.103 & $1.068^{* * *}$ & 0.289 & $-0.965^{* * *}$ & -0.412 & $-1.328^{* * *}$ & $-2.359^{* * *}$ & $-2.307^{* * *}$ & 0.0163 & $-0.0946^{* * *}$ \\
\hline & $(0.274)$ & $(0.0553)$ & $(0.370)$ & $(0.0677)$ & $(0.325)$ & $(0.0761)$ & $(0.247)$ & $(0.0853)$ & $(0.0175)$ & $(0.0120)$ \\
\hline \multirow[t]{2}{*}{$\mathrm{ROA}_{i, t-1}$} & $0.221^{* * *}$ & $0.379^{* * *}$ & -0.0228 & $-0.204^{* * *}$ & $-0.136^{* *}$ & $-0.325^{* * *}$ & $0.274^{* * *}$ & $0.184^{* * *}$ & $0.0111^{* *}$ & $0.00443^{* *}$ \\
\hline & $(0.0359)$ & $(0.0115)$ & $(0.0466)$ & $(0.0166)$ & $(0.0533)$ & $(0.0172)$ & $(0.0490)$ & $(0.0137)$ & $(0.00460)$ & $(0.00185)$ \\
\hline \multirow{2}{*}{$\mathrm{NPL}_{i, t-1}$} & $0.0531^{* *}$ & $0.0917^{* * *}$ & $-0.102^{* * *}$ & $-0.142^{* * *}$ & $-0.138^{* * *}$ & $-0.195^{* * *}$ & $-0.243^{* * *}$ & $-0.296^{* * *}$ & -0.00258 & 0.000519 \\
\hline & $(0.0214)$ & $(0.00384)$ & $(0.0265)$ & $(0.00610)$ & $(0.0330)$ & $(0.00660)$ & $(0.0394)$ & $(0.00745)$ & $(0.00554)$ & $(0.000959)$ \\
\hline GDP growth $_{t-1}$ & $(0.201)$ & $(0.0328)$ & $(0.270)$ & $(0.0509)$ & $(0.253)$ & $(0.0514)$ & $(0.223)$ & $(0.0539)$ & $(0.0208)$ & $(0.0107)$ \\
\hline \multirow[t]{2}{*}{$M \& A_{i, t-1}$} & $0.906^{* * *}$ & $1.408^{* * *}$ & $3.033^{* * *}$ & $3.244^{* * *}$ & $2.175^{* * *}$ & $3.610^{* * *}$ & $-15.36^{* * *}$ & $-13.11^{* * *}$ & 0.0184 & $0.0178^{* * *}$ \\
\hline & $(0.111)$ & $(0.0392)$ & $(0.210)$ & $(0.0676)$ & $(0.245)$ & $(0.0777)$ & $(0.267)$ & $(0.0805)$ & $(0.0160)$ & $(0.00658)$ \\
\hline Banks fixed effect & yes & yes & yes & yes & yes & yes & yes & yes & yes & yes \\
\hline time fixed effect & yes & yes & yes & yes & yes & yes & yes & yes & yes & yes \\
\hline$\varphi_{1}+\varphi_{4}$ & 0.463 & 1.141 & 0.396 & -0.904 & -1.272 & -1.312 & -3.570 & -2.141 & -0.0327 & -0.253 \\
\hline Wald test $p$ value & 0.361 & 0.000 & 0.552 & 0.000 & 0.0484 & 0.000 & 0.000 & 0.000 & 0.546 & 0.000 \\
\hline r2 & 0.0770 & 0.210 & 0.115 & 0.0894 & 0.0762 & 0.130 & 0.625 & 0.542 & 0.415 & 0.525 \\
\hline $\mathrm{N}$ & 17408 & 249459 & 17181 & 248520 & 17181 & 248527 & 17408 & 249459 & 17082 & 237443 \\
\hline
\end{tabular}


TABLE 2B: Impact of severe market liquidity shortages $\left(90^{\text {th }}\right.$ percentile) according to gap between actual and target capital

This table displays the impact of market liquidity shortages on the change in total capital ratio ( $\triangle \mathrm{TCR})$, on the change in asset part of risk weighted assets ( $\triangle \mathrm{RWA})$, on the change in asset part of total loans ( $\triangle \mathrm{LOAN}$ ), on the change in total assets ( $\triangle \mathrm{ASSET}$ ) and on dividend to total assets ratio (DIVIDEND) according to whether or not the bank is operating below its target total capital ratio. MLS $\mathrm{S}_{\mathrm{t}-1}$ is a dummy variable that is equal

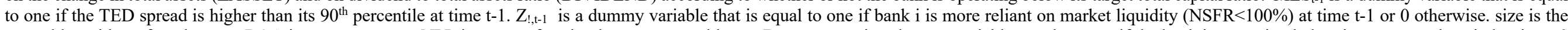

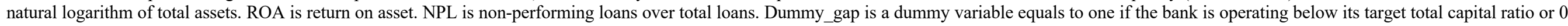

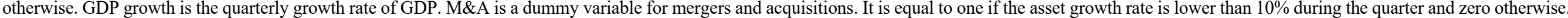

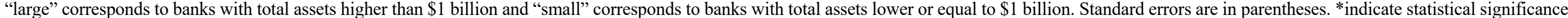
at the $10 \%$ level. $* *$ indicate statistical significance at the $5 \%$ level. $* * *$ indicate statistical significance at the $1 \%$ level.

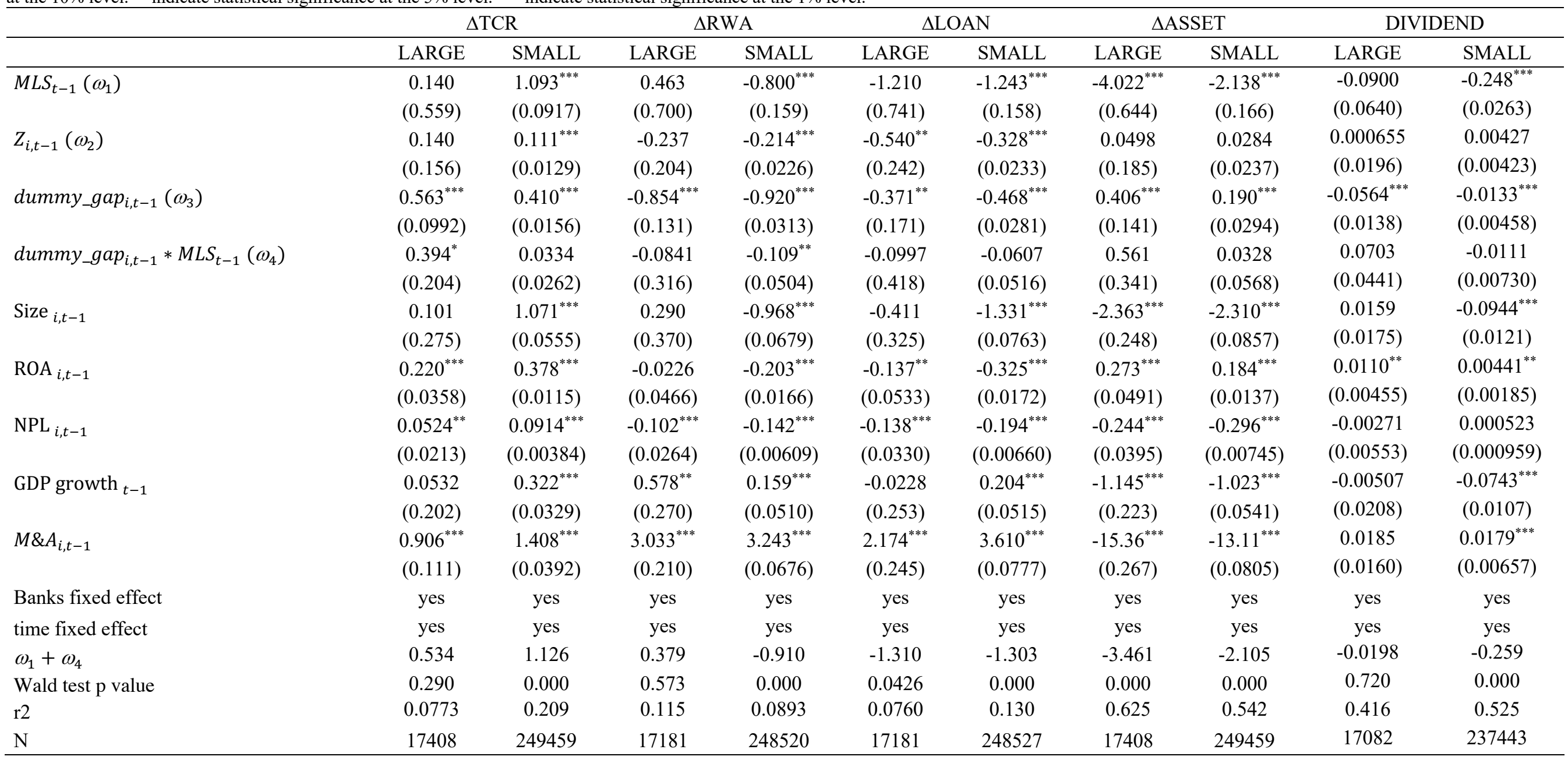


TABLE 3B: Impact of severe market liquidity shortages (mean plus two times standard deviation) according to bank liquidity level

This table displays the impact of market liquidity shortages on the change in total capital ratio $(\triangle \mathrm{TCR})$, on the change in asset part of risk weighted assets ( $\triangle \mathrm{RWA})$, on the change in asset part of total loans ( $\triangle \mathrm{LOAN}$ ), on the change in total assets ( $\triangle \mathrm{ASSET}$ ) and on dividend to total assets ratio (DIVIDEND) according to whether or not the bank is more reliant on market liquidity. MLS $\mathrm{t}_{-1}$ is a dummy variable that is equal to one if

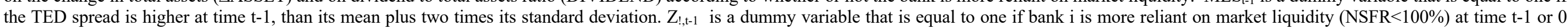

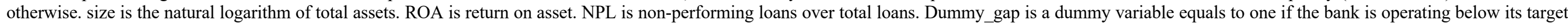

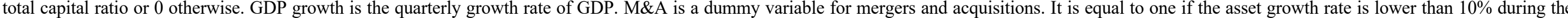

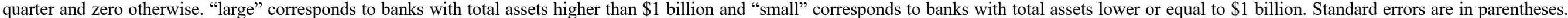
*indicate statistical significance at the $10 \%$ level. **indicate statistical significance at the $5 \%$ level. ***indicate statistical significance at the $1 \%$ level.

\begin{tabular}{|c|c|c|c|c|c|c|c|c|c|c|}
\hline & \multicolumn{2}{|c|}{$\triangle \mathrm{TCR}$} & \multicolumn{2}{|c|}{$\Delta \mathrm{RWA}$} & \multicolumn{2}{|c|}{$\triangle \mathrm{LOAN}$} & \multicolumn{2}{|c|}{$\triangle \mathrm{ASSET}$} & \multicolumn{2}{|c|}{ DIVIDEND } \\
\hline & LARGE & SMALL & LARGE & SMALL & LARGE & SMALL & LARGE & SMALL & LARGE & SMALL \\
\hline \multirow[t]{2}{*}{$M L S_{t-1}\left(\varphi_{1}\right)$} & 0.0639 & $0.983^{* * *}$ & 0.371 & $-0.750^{* * *}$ & $-2.040^{* *}$ & $-1.231^{* * *}$ & $-3.825^{* * *}$ & $-2.045^{* * *}$ & -0.0848 & $-0.248^{* * *}$ \\
\hline & $(0.696)$ & $(0.103)$ & $(0.931)$ & $(0.177)$ & $(0.893)$ & $(0.176)$ & $(0.931)$ & $(0.177)$ & $(0.0742)$ & $(0.0276)$ \\
\hline \multirow[t]{2}{*}{$Z_{i, t-1}\left(\varphi_{2}\right)$} & 0.129 & $0.105^{* * *}$ & -0.238 & $-0.209^{* * *}$ & $-0.566^{* *}$ & $-0.326^{* * *}$ & 0.0443 & 0.0327 & -0.000663 & 0.00448 \\
\hline & $(0.153)$ & $(0.0131)$ & $(0.206)$ & $(0.0229)$ & $(0.243)$ & $(0.0234)$ & $(0.188)$ & $(0.0239)$ & $(0.0197)$ & $(0.00428)$ \\
\hline \multirow[t]{2}{*}{$d u m m y \_g a p_{i, t-1}\left(\varphi_{3}\right)$} & $0.598^{* * *}$ & $0.414^{* * *}$ & $-0.862^{* * *}$ & $-0.931^{* * *}$ & $-0.380^{* *}$ & $-0.474^{* * *}$ & $0.455^{* * *}$ & $0.193^{* * *}$ & $-0.0502^{* * *}$ & $-0.0144^{* * *}$ \\
\hline & $(0.0966)$ & $(0.0154)$ & $(0.129)$ & $(0.0308)$ & $(0.168)$ & $(0.0276)$ & $(0.139)$ & $(0.0290)$ & $(0.0127)$ & $(0.00448)$ \\
\hline \multirow[t]{2}{*}{$Z_{i, t-1} * M L S_{t-1}\left(\varphi_{4}\right)$} & 0.402 & $0.160^{* * *}$ & 0.0256 & -0.123 & 0.774 & -0.0479 & 0.258 & -0.102 & 0.0522 & -0.00487 \\
\hline & $(0.489)$ & $(0.0529)$ & $(0.662)$ & $(0.0996)$ & $(0.624)$ & $(0.0967)$ & $(0.769)$ & $(0.0862)$ & $(0.0469)$ & $(0.0116)$ \\
\hline \multirow[t]{2}{*}{ Size $_{i, t-1}$} & 0.103 & $1.070^{* * *}$ & 0.289 & $-0.971^{* * *}$ & -0.412 & $-1.333^{* * *}$ & $-2.359^{* * *}$ & $-2.307^{* * *}$ & 0.0163 & $-0.0948^{* * *}$ \\
\hline & $(0.274)$ & $(0.0553)$ & $(0.370)$ & $(0.0678)$ & $(0.325)$ & $(0.0762)$ & $(0.247)$ & $(0.0852)$ & $(0.0175)$ & $(0.0120)$ \\
\hline \multirow{2}{*}{$\mathrm{ROA}_{i, t-1}$} & $0.221^{* * *}$ & $0.378^{* * *}$ & -0.0228 & $-0.203^{* * *}$ & $-0.137^{* *}$ & $-0.325^{* * *}$ & $0.274^{* * *}$ & $0.184^{* * *}$ & $0.0111^{* *}$ & $0.00444^{* *}$ \\
\hline & $(0.0359)$ & $(0.0115)$ & $(0.0466)$ & $(0.0166)$ & $(0.0533)$ & $(0.0172)$ & $(0.0490)$ & $(0.0137)$ & $(0.00459)$ & $(0.00185)$ \\
\hline $\mathrm{NPL}_{i, t-1}$ & $0.0530^{* *}$ & $0.0914^{* * *}$ & $-0.102^{* * *}$ & $-0.142^{* * *}$ & $-0.138^{* * *}$ & $-0.194^{* * *}$ & $-0.243^{* * *}$ & $-0.296^{* * *}$ & -0.00259 & 0.000531 \\
\hline \multirow{2}{*}{ GDP growth ${ }_{t-1}$} & 0.0547 & $0.322^{* * *}$ & $0.577^{* *}$ & $0.158^{* * *}$ & -0.0248 & $0.203^{* * *}$ & $-1.142^{* * *}$ & $-1.021^{* * *}$ & -0.00478 & $-0.0745^{* * *}$ \\
\hline & $(0.201)$ & $(0.0328)$ & $(0.270)$ & $(0.0509)$ & $(0.253)$ & $(0.0514)$ & $(0.223)$ & $(0.0539)$ & $(0.0208)$ & $(0.0107)$ \\
\hline \multirow[t]{2}{*}{$M \& A_{i, t-1}$} & $0.905^{* * *}$ & $1.408^{* * *}$ & $3.033^{* * *}$ & $3.243^{* * *}$ & $2.174^{* * *}$ & $3.610^{* * *}$ & $-15.36^{* * *}$ & $-13.11^{* * *}$ & 0.0183 & $0.0178^{* * *}$ \\
\hline & $(0.111)$ & $(0.0392)$ & $(0.211)$ & $(0.0676)$ & $(0.244)$ & $(0.0777)$ & $(0.267)$ & $(0.0805)$ & $(0.0160)$ & $(0.00658)$ \\
\hline Banks fixed effect & yes & yes & yes & yes & yes & yes & yes & yes & yes & yes \\
\hline time fixed effect & yes & yes & yes & yes & yes & yes & yes & yes & yes & yes \\
\hline$\varphi_{1}+\varphi_{4}$ & 0.466 & 1.143 & 0.397 & -0.874 & -1.266 & -1.279 & -3.567 & -2.147 & -0.0326 & -0.253 \\
\hline Wald test $p$ value & 0.359 & 0.000 & 0.551 & 0.000 & 0.0495 & 0.000 & 0.000 & 0.000 & 0.548 & 0.000 \\
\hline $\mathrm{r} 2$ & 0.0770 & 0.210 & 0.115 & 0.0893 & 0.0762 & 0.130 & 0.625 & 0.542 & 0.415 & 0.525 \\
\hline $\mathrm{N}$ & 17408 & 249459 & 17181 & 248520 & 17181 & 248527 & 17408 & 249459 & 17082 & 237443 \\
\hline
\end{tabular}


TABLE 4B: Impact of severe market liquidity shortages (mean plus two times standard deviation) according to gap between actual and target capital

This table displays the impact of market liquidity shortages on the change in total capital ratio $(\triangle \mathrm{TCR})$, on the change in asset part of risk weighted assets $(\triangle \mathrm{RWA})$, on the change in asset part of total loans ( $\triangle \mathrm{LOAN}$ ), on the change in total assets ( $\triangle \mathrm{ASSET}$ ) and on dividend to total assets ratio (DIVIDEND) according to whether or not the bank is operating below its target total capital ratio. MLS $\mathrm{S}_{\mathrm{t}-1}$ is a dummy variable that is equal

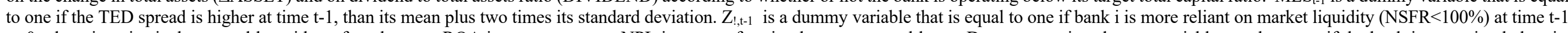

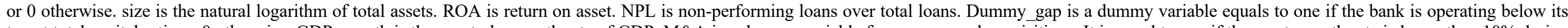

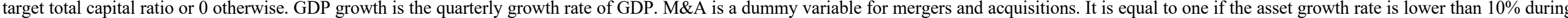

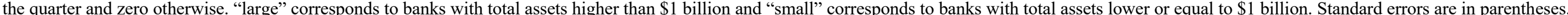
*indicate statistical significance at the $10 \%$ level. **indicate statistical significance at the $5 \%$ level. ***indicate statistical significance at the $1 \%$ level.

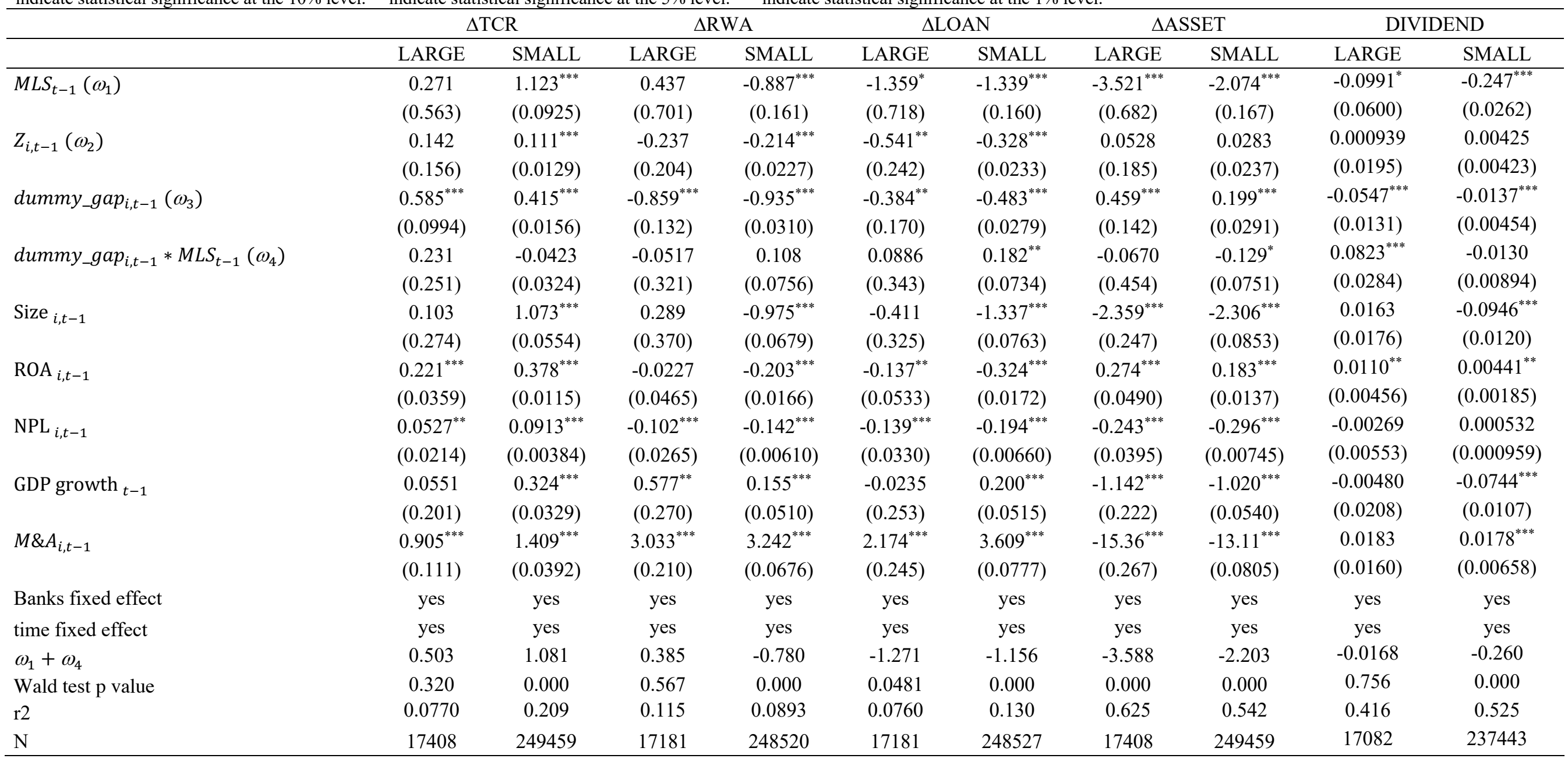


TABLE 5B: Impact of market liquidity shortages on banks' liquid assets according to bank liquidity level

This table displays the impact of market liquidity shortages on the change in asset part of liquid assets according to whether or not the bank is more reliant on market liquidity. $\mathrm{MLS}_{\mathrm{t}-1}$ is a dummy variable that is equal to one if the TED spread is higher than its $75^{\text {th }}$ percentile at time $t-1 . Z_{!, t-1}$ is a dummy variable that is equal to one if bank $i$ is more reliant on market liquidity (NSFR $<100 \%$ ) at time t-1 or 0 otherwise. size is the natural logarithm of total assets. ROA is return on asset. NPL is nonperforming loans over total loans. Dummy_gap is a dummy variable equals to one if the bank is operating below its target total capital ratio $\left(G A P_{i, t-1}>0\right)$ or 0 otherwise. GDP growth is the quarterly growth rate of GDP. M\&A is a dummy variable for mergers and acquisitions. It is equal to one if the asset growth rate is lower than $10 \%$ during the quarter and zero otherwise. "large" corresponds to banks with total assets higher than $\$ 1$ billion and "small" corresponds to banks with total assets lower or equal to $\$ 1$ billion. Standard errors are in parentheses. *indicate statistical significance at the $10 \%$ level. **indicate statistical significance at the $5 \%$ level. $* * *$ indicate statistical significance at the $1 \%$ level.

\begin{tabular}{lcccc}
\hline & \multicolumn{2}{c}{ Whole period } & \multicolumn{2}{c}{ Non-crisis period } \\
\hline$M L S_{t-1}\left(\varphi_{1}\right)$ & LARGE & SMALL & LARGE & SMALL \\
$Z_{i, t-1}\left(\varphi_{2}\right)$ & 1.005 & 0.0427 & 0.605 & -0.0608 \\
& $(0.805)$ & $(0.182)$ & $(0.888)$ & $(0.182)$ \\
dummy_gap $_{i, t-1}\left(\varphi_{3}\right)$ & $0.661^{* * *}$ & $0.246^{* * *}$ & $0.681^{* * *}$ & $0.242^{* * *}$ \\
& $(0.242)$ & $(0.0267)$ & $(0.247)$ & $(0.0276)$ \\
$Z_{i, t-1} * M L S_{t-1}\left(\varphi_{4}\right)$ & $0.467^{* * *}$ & $0.560^{* * *}$ & $0.450^{* * *}$ & $0.609^{* * *}$ \\
& $(0.157)$ & $(0.0291)$ & $(0.168)$ & $(0.0311)$ \\
Size & -0.0548 & $0.199^{* * *}$ & 0.468 & $0.161^{* * *}$ \\
& $(0.371)$ & $(0.0446)$ & $(0.512)$ & $(0.0555)$ \\
ROA $_{i, t-1}$ & 0.336 & $1.138^{* * *}$ & 0.397 & $0.963^{* * *}$ \\
& $(0.244)$ & $(0.0719)$ & $(0.276)$ & $(0.0709)$ \\
NPL $_{i, t-1}$ & 0.0403 & $0.275^{* * *}$ & 0.0795 & $0.255^{* * *}$ \\
GDP growth $_{t-1}$ & $(0.0523)$ & $(0.0170)$ & $(0.0670)$ & $(0.0192)$ \\
& $0.101^{* * *}$ & $0.165^{* * *}$ & $0.103^{* * *}$ & $0.149^{* * *}$ \\
$M \& A_{i, t-1}$ & $(0.0325)$ & $(0.00657)$ & $(0.0363)$ & $(0.00715)$ \\
& -0.310 & $-0.571^{* * *}$ & -0.317 & $-0.571^{* * *}$ \\
Banks fixed effect & $(0.392)$ & $(0.110)$ & $(0.393)$ & $(0.110)$ \\
time fixed effect & $-1.815^{* * *}$ & $-3.639^{* * *}$ & $-1.613^{* * *}$ & $-3.619^{* * *}$ \\
$\varphi_{1}+\varphi_{4}$ & $(0.254)$ & $(0.0867)$ & $(0.279)$ & $(0.0897)$ \\
Wald test p value $_{\text {r2 }}$ & yes & yes & yes & yes \\
N & yes & yes & yes & yes \\
\hline
\end{tabular}


TABLE 6B: Impact of market liquidity shortages on banks' liquid assets according to gap between actual and target capital

This table displays the impact of market liquidity shortages on the change in asset part of liquid assets according to whether or not the bank is operating below its target total capital ratio. $\mathrm{MLS}_{\mathrm{t}-1}$ is a dummy variable that is equal to one if the TED spread is higher than its $75^{\text {th }}$ percentile at time $t-1 . Z_{t, t-1}$ is a dummy variable that is equal to one if bank $i$ is more reliant on market liquidity (NSFR $<100 \%$ ) at time t- 1 or 0 otherwise. size is the natural logarithm of total assets. ROA is return on asset. NPL is non-performing loans over total loans. Dummy_gap is a dummy variable equals to one if the bank is operating below its target total capital ratio $\left(G A P_{i, t-1}>0\right)$ or 0 otherwise. GDP growth is the quarterly growth rate of GDP. M\&A is a dummy variable for mergers and acquisitions. It is equal to one if the asset growth rate is lower than $10 \%$ during the quarter and zero otherwise. "large" corresponds to banks with total assets higher than $\$ 1$ billion and "small" corresponds to banks with total assets lower or equal to $\$ 1$ billion. Standard errors are in parentheses. *indicate statistical significance at the $10 \%$ level. **indicate statistical significance at the $5 \%$ level. $* * *$ indicate statistical significance at the $1 \%$ level.

\begin{tabular}{lcccc}
\hline & \multicolumn{2}{c}{ Whole period } & \multicolumn{2}{c}{ Non-crisis period } \\
\hline$M L S_{t-1}\left(\omega_{1}\right)$ & LARGE & SMALL & LARGE & SMALL \\
$Z_{i, t-1}\left(\omega_{2}\right)$ & 0.776 & 0.131 & 0.671 & -0.00394 \\
& $(0.720)$ & $(0.180)$ & $(0.744)$ & $(0.180)$ \\
dummy_gap $_{i, t-1}\left(\omega_{3}\right)$ & $0.648^{* * *}$ & $0.296^{* * *}$ & $0.734^{* * *}$ & $0.266^{* * *}$ \\
& $(0.231)$ & $(0.0256)$ & $(0.241)$ & $(0.0267)$ \\
dummy_gap $_{i, t-1} * M L S_{t-1}\left(\omega_{4}\right)$ & $0.413^{* *}$ & $0.538^{* * *}$ & $0.398^{* *}$ & $0.592^{* * *}$ \\
& $(0.163)$ & $(0.0305)$ & $(0.172)$ & $(0.0319)$ \\
Size $_{i, t-1}$ & 0.235 & $0.0911^{* *}$ & 0.458 & $0.138^{* * *}$ \\
& $(0.251)$ & $(0.0376)$ & $(0.385)$ & $(0.0529)$ \\
ROA $_{i, t-1}$ & 0.338 & $1.142^{* * *}$ & 0.400 & $0.966^{* * *}$ \\
& $(0.244)$ & $(0.0720)$ & $(0.277)$ & $(0.0710)$ \\
NPL $_{i, t-1}$ & 0.0401 & $0.275^{* * *}$ & 0.0791 & $0.255^{* * *}$ \\
GDP growth $_{t-1}$ & $(0.0523)$ & $(0.0170)$ & $(0.0669)$ & $(0.0192)$ \\
& $0.101^{* * *}$ & $0.164^{* * *}$ & $0.102^{* * *}$ & $0.149^{* * *}$ \\
$M \& A_{i, t-1}$ & $(0.0325)$ & $(0.00656)$ & $(0.0363)$ & $(0.00715)$ \\
& -0.310 & $-0.571^{* * *}$ & -0.317 & $-0.571^{* * *}$ \\
Banks fixed effect & $(0.392)$ & $(0.110)$ & $(0.393)$ & $(0.110)$ \\
time fixed effect & $-1.817^{* * *}$ & $-3.638^{* * *}$ & $-1.609^{* * *}$ & $-3.619^{* * *}$ \\
$\omega_{1}+\omega_{4}$ & $(0.254)$ & $(0.0867)$ & $(0.279)$ & $(0.0897)$ \\
Wald test p value & yes & yes & yes & yes \\
r2 & yes & yes & yes & yes \\
N & 1.011 & 0.222 & 1.129 & 0.134 \\
& 0.166 & 0.222 & 0.134 & 0.472 \\
& 0.0588 & 0.0992 & 0.0588 & 0.101 \\
& 17408 & 249449 & 14841 & 215743 \\
\hline
\end{tabular}


TABLE 7B: adjustment speed of small banks during periods of market liquidity shortage

This table displays the estimations results of equation (11): $\triangle T C R_{i, t}=\Lambda V_{i, t-1} G A P_{i, t-1}+\varepsilon_{i, t}$ using OLS methods. It illustrates the speed of adjustment of small banks during period of market liquidity shortages. The market liquidity shortage is measured by spikes in TED spread. $Z$ is a dummy variable equals to one if banks has NSFR lower than $100 \%$ or 0 if otherwise. It captures banks more reliant on market liquidity. Dummy_gap is a dummy variable equals to one if the bank is operating below its target total capital ratio or 0 otherwise. It captures banks operating below their target capital ratio. $\triangle \mathrm{TCR}$ is change in total capital ratio. NPL is non-performing loans to total loans ratio. Standard errors are in parentheses. *indicate statistical significance at the $10 \%$ level. **indicate statistical significance at the $5 \%$ level. ***indicate statistical significance at the $1 \%$ level.

\begin{tabular}{lc}
\hline & $\Delta \mathrm{TCR}$ \\
\hline$Z_{i, t-1}$ & $0.0675^{* * *}$ \\
& $(0.00631)$ \\
dummy_gap $p_{i, t-1}$ & $0.126^{* * *}$ \\
& $(0.0113)$ \\
NPL $i, t-1$ & $-0.00678^{* * *}$ \\
& $(0.00176)$ \\
constant & $-0.387^{* * *}$ \\
Time fixed effect & $(0.0366)$ \\
$\mathrm{r} 2$ & yes \\
\hline
\end{tabular}




\section{APPENDIX C}

TABLE 1C: Impact of market liquidity shortages according to banks liquidity level, using the $10^{\text {th }}$ percentile of NSFR

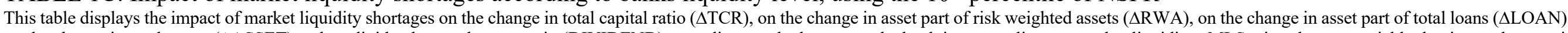

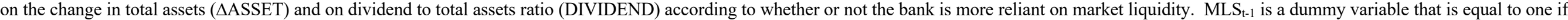

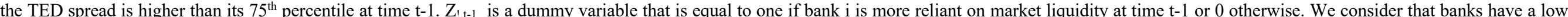

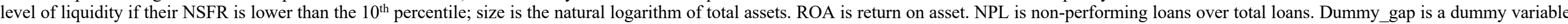

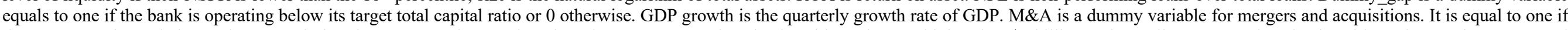

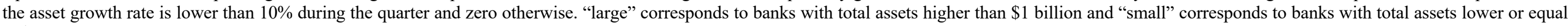
to $\$ 1$ billion. Standard errors are in parentheses. *indicate statistical significance at the $10 \%$ level. $* *$ indicate statistical significance at the $5 \%$ level. $* * *$ indicate statistical significance at the $1 \%$ level.

\begin{tabular}{|c|c|c|c|c|c|c|c|c|c|c|}
\hline & \multicolumn{2}{|c|}{$\Delta \mathrm{TCR}$} & \multicolumn{2}{|c|}{$\Delta \mathrm{RWA}$} & \multicolumn{2}{|c|}{$\triangle \mathrm{LOAN}$} & \multicolumn{2}{|c|}{$\triangle \mathrm{ASSET}$} & \multicolumn{2}{|c|}{ DIVIDEND } \\
\hline & LARGE & SMALL & LARGE & SMALL & LARGE & SMALL & LARGE & SMALL & LARGE & SMALL \\
\hline \multirow{2}{*}{$M L S_{t-1}\left(\varphi_{1}\right)$} & -0.496 & $0.320^{* * *}$ & $1.269^{*}$ & $-0.500^{* * *}$ & -0.111 & $-0.507^{* * *}$ & -0.0141 & $-0.441^{* *}$ & $0.0754^{*}$ & $0.0471^{*}$ \\
\hline & $(0.576)$ & $(0.0963)$ & $(0.712)$ & $(0.155)$ & $(0.729)$ & $(0.151)$ & $(0.622)$ & $(0.171)$ & $(0.0445)$ & $(0.0256)$ \\
\hline \multirow[t]{2}{*}{$Z_{i, t-1}\left(\varphi_{2}\right)$} & -0.0570 & 0.00230 & 0.0148 & $-0.123^{* * *}$ & -0.188 & $-0.230^{* * *}$ & -0.0261 & -0.0325 & 0.000943 & 0.00551 \\
\hline & $(0.0723)$ & $(0.0132)$ & $(0.134)$ & $(0.0240)$ & $(0.148)$ & $(0.0256)$ & $(0.140)$ & $(0.0279)$ & $(0.0103)$ & $(0.00383)$ \\
\hline \multirow{2}{*}{$d u m m y_{-} g a p_{i, t-1}\left(\varphi_{3}\right)$} & $0.599^{* * *}$ & $0.415^{* * *}$ & $-0.858^{* * *}$ & $-0.932^{* * *}$ & $-0.379^{* *}$ & $-0.477^{* * *}$ & $0.454^{* * *}$ & $0.193^{* * *}$ & $-0.0499^{* * *}$ & $-0.0143^{* * *}$ \\
\hline & $(0.0963)$ & $(0.0154)$ & $(0.129)$ & $(0.0308)$ & $(0.168)$ & $(0.0276)$ & $(0.140)$ & $(0.0290)$ & $(0.0126)$ & $(0.00447)$ \\
\hline \multirow{2}{*}{$Z_{i, t-1} * M L S_{t-1}\left(\varphi_{4}\right)$} & 0.140 & $0.139^{* * *}$ & $-0.338^{* *}$ & $-0.290^{* * *}$ & -0.195 & $-0.288^{* * *}$ & 0.119 & $0.0980^{* *}$ & -0.0138 & 0.000783 \\
\hline & $(0.0966)$ & $(0.0194)$ & $(0.172)$ & $(0.0385)$ & $(0.185)$ & $(0.0373)$ & $(0.196)$ & $(0.0403)$ & $(0.0184)$ & $(0.00567)$ \\
\hline \multirow{2}{*}{ Size $_{i, t-1}$} & 0.113 & $1.076^{* * *}$ & 0.286 & $-0.966^{* * *}$ & -0.422 & $-1.330^{* * *}$ & $-2.358^{* * *}$ & $-2.309^{* * *}$ & 0.0169 & $-0.0949^{* * *}$ \\
\hline & $(0.273)$ & $(0.0555)$ & $(0.368)$ & $(0.0679)$ & $(0.324)$ & $(0.0764)$ & $(0.248)$ & $(0.0852)$ & $(0.0176)$ & $(0.0120)$ \\
\hline \multirow[t]{2}{*}{$\mathrm{ROA}_{i, t-1}$} & $0.223^{* * *}$ & $0.381^{* * *}$ & -0.0263 & $-0.207^{* * *}$ & $-0.140^{* * *}$ & $-0.330^{* * *}$ & $0.275^{* * *}$ & $0.185^{* * *}$ & $0.0110^{* *}$ & $0.00447^{* *}$ \\
\hline & $(0.0359)$ & $(0.0115)$ & $(0.0463)$ & $(0.0167)$ & $(0.0529)$ & $(0.0173)$ & $(0.0489)$ & $(0.0137)$ & $(0.00454)$ & $(0.00185)$ \\
\hline \multirow[t]{2}{*}{$\mathrm{NPL}_{i, t-1}$} & $0.0555^{* *}$ & $0.0955^{* * *}$ & $-0.103^{* * *}$ & $-0.140^{* * *}$ & $-0.138^{* * *}$ & $-0.191^{* * *}$ & $-0.242^{* * *}$ & $-0.294^{* * *}$ & -0.00255 & 0.000335 \\
\hline & $(0.0216)$ & $(0.00392)$ & $(0.0270)$ & $(0.00630)$ & $(0.0330)$ & $(0.00684)$ & $(0.0392)$ & $(0.00764)$ & $(0.00549)$ & $(0.00103)$ \\
\hline GDP growth $_{t-1}$ & $(0.307)$ & $(0.0544)$ & $(0.297)$ & $(0.0934)$ & $(0.373)$ & $(0.0916)$ & $(0.270)$ & $(0.0989)$ & $(0.0192)$ & $(0.0112)$ \\
\hline \multirow{2}{*}{$M \& A_{i, t-1}$} & $0.906^{* * *}$ & $1.410^{* * *}$ & $3.035^{* * *}$ & $3.243^{* * *}$ & $2.174^{* * *}$ & $3.609^{* * *}$ & $-15.36^{* * *}$ & $-13.11^{* * *}$ & 0.0185 & $0.0178^{* * *}$ \\
\hline & $(0.112)$ & $(0.0392)$ & $(0.210)$ & $(0.0676)$ & $(0.245)$ & $(0.0777)$ & $(0.267)$ & $(0.0805)$ & $(0.0160)$ & $(0.00658)$ \\
\hline Banks fixed effect & yes & yes & yes & yes & yes & yes & yes & yes & yes & yes \\
\hline time fixed effect & yes & yes & yes & yes & yes & yes & yes & yes & yes & yes \\
\hline$\varphi_{1}+\varphi_{4}$ & -0.355 & 0.459 & 0.931 & -0.790 & -0.306 & -0.795 & 0.104 & -0.343 & 0.0616 & 0.0479 \\
\hline Wald test $p$ value & 0.527 & 0.000 & 0.180 & 0.000 & 0.667 & 0.000 & 0.862 & 0.0476 & 0.130 & 0.0586 \\
\hline $\mathrm{r} 2$ & 0.0768 & 0.209 & 0.116 & 0.0894 & 0.0756 & 0.130 & 0.625 & 0.542 & 0.415 & 0.525 \\
\hline $\mathrm{N}$ & 17408 & 249459 & 17181 & 248520 & 17181 & 248527 & 17408 & 249459 & 17082 & 237443 \\
\hline
\end{tabular}


TABLE 2C: Impact of severe market liquidity shortages $\left(90^{\text {th }}\right.$ percentile) according to banks liquidity level, using the $10^{\text {th }}$ percentile of NSFR

This table displays the impact of market liquidity shortages on the change in total capital ratio $(\triangle \mathrm{TCR})$, on the change in asset part of risk weighted assets ( $\triangle \mathrm{RWA})$, on the change in asset part of total loans ( $\triangle \mathrm{LOAN}$ ), on the change in total assets ( $\triangle \mathrm{ASSET}$ ) and on dividend to total assets ratio (DIVIDEND) according to whether or not the bank is more reliant on market liquidity. MLS $\mathrm{S}_{\mathrm{t}-1}$ is a dummy variable that is equal to one if

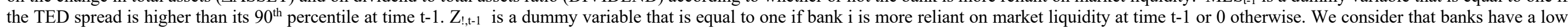

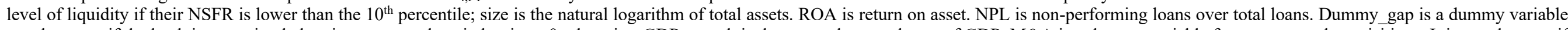

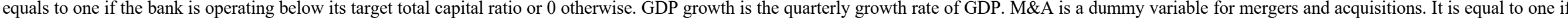

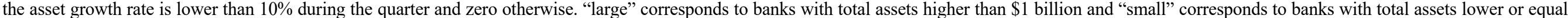

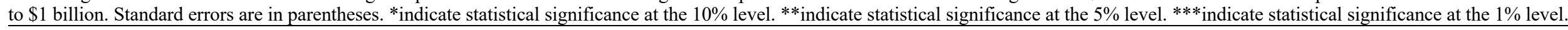

\begin{tabular}{|c|c|c|c|c|c|c|c|c|c|c|}
\hline & \multicolumn{2}{|c|}{$\Delta \mathrm{TCR}$} & \multicolumn{2}{|c|}{$\Delta \mathrm{RWA}$} & \multicolumn{2}{|c|}{$\triangle \mathrm{LOAN}$} & \multicolumn{2}{|c|}{$\triangle \mathrm{ASSET}$} & \multicolumn{2}{|c|}{ DIVIDEND } \\
\hline & LARGE & SMALL & LARGE & SMALL & LARGE & SMALL & LARGE & SMALL & LARGE & SMALL \\
\hline \multirow{2}{*}{$M L S_{t-1}\left(\varphi_{1}\right)$} & 0.222 & $1.059^{* * *}$ & 0.595 & $-0.753^{* * *}$ & $-1.396^{* *}$ & $-1.205^{* * *}$ & $-3.578^{* * *}$ & $-2.153^{* * *}$ & -0.0253 & $-0.248^{* * *}$ \\
\hline & $(0.552)$ & $(0.0917)$ & $(0.725)$ & $(0.160)$ & $(0.683)$ & $(0.160)$ & $(0.626)$ & $(0.166)$ & $(0.0583)$ & $(0.0266)$ \\
\hline \multirow{2}{*}{$Z_{i, t-1}\left(\varphi_{2}\right)$} & -0.0518 & $0.0257^{* *}$ & -0.0455 & $-0.176^{* * *}$ & $-0.246^{*}$ & $-0.286^{* * *}$ & 0.00362 & -0.0134 & -0.00145 & $0.00658^{*}$ \\
\hline & $(0.0663)$ & $(0.0125)$ & $(0.128)$ & $(0.0231)$ & $(0.141)$ & $(0.0245)$ & $(0.133)$ & $(0.0267)$ & $(0.00901)$ & $(0.00364)$ \\
\hline \multirow{2}{*}{$d u m m y \_g a p_{i, t-1}\left(\varphi_{3}\right)$} & $0.601^{* * *}$ & $0.415^{* * *}$ & $-0.864^{* * *}$ & $-0.932^{* * *}$ & $-0.383^{* *}$ & $-0.477^{* * *}$ & $0.456^{* * *}$ & $0.194^{* * *}$ & $-0.0501^{* * *}$ & $-0.0143^{* * *}$ \\
\hline & $(0.0960)$ & $(0.0154)$ & $(0.129)$ & $(0.0308)$ & $(0.168)$ & $(0.0276)$ & $(0.139)$ & $(0.0290)$ & $(0.0127)$ & $(0.00447)$ \\
\hline \multirow{2}{*}{$Z_{i, t-1} * M L S_{t-1}\left(\varphi_{4}\right)$} & $0.279^{* *}$ & $0.117^{* * *}$ & -0.248 & $-0.212^{* * *}$ & 0.0654 & $-0.184^{* * *}$ & 0.0107 & 0.0618 & -0.00964 & -0.00673 \\
\hline & $(0.136)$ & $(0.0265)$ & $(0.229)$ & $(0.0523)$ & $(0.207)$ & $(0.0546)$ & $(0.247)$ & $(0.0555)$ & $(0.0231)$ & $(0.00691)$ \\
\hline \multirow[t]{2}{*}{$\operatorname{Size}_{i, t-1}$} & 0.110 & $1.079^{* * *}$ & 0.285 & $-0.973^{* * *}$ & -0.427 & $-1.338^{* * *}$ & $-2.356^{* * *}$ & $-2.306^{* * *}$ & 0.0169 & $-0.0947^{* * *}$ \\
\hline & $(0.274)$ & $(0.0555)$ & $(0.370)$ & $(0.0680)$ & $(0.325)$ & $(0.0766)$ & $(0.248)$ & $(0.0851)$ & $(0.0175)$ & $(0.0120)$ \\
\hline \multirow[t]{2}{*}{$\mathrm{ROA}_{i, t-1}$} & $0.223^{* * *}$ & $0.380^{* * *}$ & -0.0252 & $-0.206^{* * *}$ & $-0.139^{* * *}$ & $-0.328^{* * *}$ & $0.274^{* * *}$ & $0.185^{* * *}$ & $0.0110^{* *}$ & $0.00443^{* *}$ \\
\hline & $(0.0358)$ & $(0.0115)$ & $(0.0463)$ & $(0.0167)$ & $(0.0528)$ & $(0.0173)$ & $(0.0489)$ & $(0.0137)$ & $(0.00455)$ & $(0.00185)$ \\
\hline $\mathrm{NPL}_{i, t-1}$ & $0.0554^{* *}$ & $0.0948^{* * *}$ & $-0.103^{* * *}$ & $-0.139^{* * *}$ & $-0.137^{* * *}$ & $-0.189^{* * *}$ & $-0.243^{* * *}$ & $-0.294^{* * *}$ & -0.00253 & 0.000300 \\
\hline \multirow[t]{2}{*}{ GDP growth $_{t-1}$} & 0.0517 & $0.323^{* * *}$ & $0.575^{* *}$ & $0.155^{* * *}$ & -0.0459 & $0.197^{* * *}$ & $-1.141^{* * *}$ & $-1.023^{* * *}$ & -0.00447 & $-0.0742^{* * *}$ \\
\hline & $(0.203)$ & $(0.0328)$ & $(0.270)$ & $(0.0510)$ & $(0.253)$ & $(0.0515)$ & $(0.224)$ & $(0.0539)$ & $(0.0208)$ & $(0.0107)$ \\
\hline \multirow[t]{2}{*}{$M \& A_{i, t-1}$} & $0.907^{* * *}$ & $1.410^{* * *}$ & $3.032^{* * *}$ & $3.242^{* * *}$ & $2.172^{* * *}$ & $3.608^{* * *}$ & $-15.36^{* * *}$ & $-13.11^{* * *}$ & 0.0184 & $0.0178^{* * *}$ \\
\hline & $(0.112)$ & $(0.0392)$ & $(0.210)$ & $(0.0676)$ & $(0.245)$ & $(0.0777)$ & $(0.267)$ & $(0.0805)$ & $(0.0160)$ & $(0.00658)$ \\
\hline Banks fixed effect & yes & yes & yes & yes & yes & yes & yes & yes & yes & yes \\
\hline time fixed effect & yes & yes & yes & yes & yes & yes & yes & yes & yes & yes \\
\hline$\varphi_{1}+\varphi_{4}$ & 0.501 & 1.177 & 0.347 & -0.965 & -1.331 & -1.389 & -3.568 & -2.091 & -0.0349 & -0.255 \\
\hline Wald test $\mathrm{p}$ value & 0.324 & 0.000 & 0.598 & 0.000 & 0.0385 & 0.000 & 0.000 & 0.000 & 0.525 & $2.09 \mathrm{e}-23$ \\
\hline r2 & 0.0770 & 0.209 & 0.115 & 0.0893 & 0.0755 & 0.130 & 0.625 & 0.542 & 0.415 & 0.525 \\
\hline $\mathrm{N}$ & 17408 & 249459 & 17181 & 248520 & 17181 & 248527 & 17408 & 249459 & 17082 & 237443 \\
\hline
\end{tabular}


TABLE 3C: Impact of severe market liquidity shortages (mean plus two times standard deviation) according to banks liquidity level, using the $10^{\text {th }}$ percentile of

\section{NSFR}

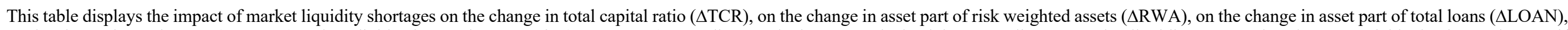

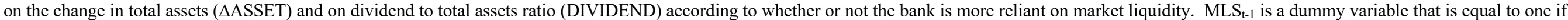

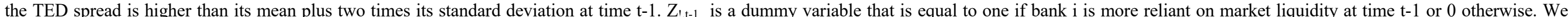

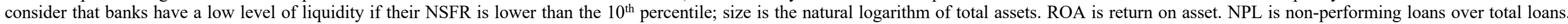

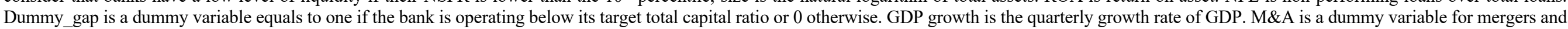

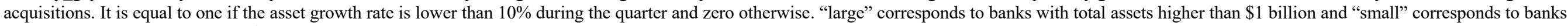

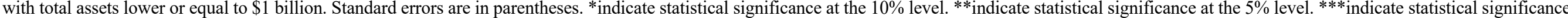
at the $1 \%$ level.

\begin{tabular}{|c|c|c|c|c|c|c|c|c|c|c|}
\hline & \multicolumn{2}{|c|}{$\Delta \mathrm{TCR}$} & \multicolumn{2}{|c|}{$\Delta \mathrm{RWA}$} & \multicolumn{2}{|c|}{$\triangle \mathrm{LOAN}$} & \multicolumn{2}{|c|}{$\triangle \mathrm{ASSET}$} & \multicolumn{2}{|c|}{ DIVIDEND } \\
\hline & LARGE & SMALL & LARGE & SMALL & LARGE & SMALL & LARGE & SMALL & LARGE & SMALL \\
\hline \multirow{2}{*}{$M L S_{t-1}\left(\varphi_{1}\right)$} & 0.170 & $1.090^{* * *}$ & 0.465 & $-0.864^{* * *}$ & $-1.635^{* *}$ & $-1.370^{* * *}$ & $-3.594^{* * *}$ & $-2.149^{* * *}$ & -0.0490 & $-0.255^{* * *}$ \\
\hline & $(0.563)$ & $(0.0937)$ & $(0.770)$ & $(0.164)$ & $(0.711)$ & $(0.163)$ & $(0.675)$ & $(0.168)$ & $(0.0582)$ & $(0.0267)$ \\
\hline \multirow{2}{*}{$Z_{i, t-1}\left(\varphi_{2}\right)$} & -0.0376 & $0.0365^{* * *}$ & -0.0676 & $-0.202^{* * *}$ & $-0.255^{*}$ & $-0.316^{* * *}$ & 0.00338 & -0.00922 & -0.00338 & 0.00532 \\
\hline & $(0.0626)$ & $(0.0122)$ & $(0.124)$ & $(0.0227)$ & $(0.136)$ & $(0.0240)$ & $(0.127)$ & $(0.0261)$ & $(0.00820)$ & $(0.00354)$ \\
\hline \multirow{2}{*}{$d u m m y_{-} g a p_{i, t-1}\left(\varphi_{3}\right)$} & $0.602^{* * *}$ & $0.415^{* * *}$ & $-0.864^{* * *}$ & $-0.932^{* * *}$ & $-0.382^{* *}$ & $-0.477^{* * *}$ & $0.457^{* * *}$ & $0.194^{* * *}$ & $-0.0501^{* * *}$ & $-0.0143^{* * *}$ \\
\hline & $(0.0962)$ & $(0.0154)$ & $(0.129)$ & $(0.0308)$ & $(0.168)$ & $(0.0276)$ & $(0.139)$ & $(0.0290)$ & $(0.0127)$ & $(0.00447)$ \\
\hline \multirow{2}{*}{$Z_{i, t-1} * M L S_{t-1}\left(\varphi_{4}\right)$} & $0.343^{*}$ & $0.0637^{*}$ & -0.105 & -0.0122 & 0.339 & 0.117 & 0.0288 & 0.0577 & 0.0173 & 0.00603 \\
\hline & $(0.207)$ & $(0.0342)$ & $(0.365)$ & $(0.0782)$ & $(0.295)$ & $(0.0745)$ & $(0.381)$ & $(0.0751)$ & $(0.0197)$ & $(0.00844)$ \\
\hline \multirow{2}{*}{ Size $_{i, t-1}$} & 0.112 & $1.082^{* * *}$ & 0.281 & $-0.979^{* * *}$ & -0.428 & $-1.346^{* * *}$ & $-2.356^{* * *}$ & $-2.305^{* * *}$ & 0.0165 & $-0.0950^{* * *}$ \\
\hline & $(0.273)$ & $(0.0555)$ & $(0.369)$ & $(0.0681)$ & $(0.325)$ & $(0.0766)$ & $(0.247)$ & $(0.0850)$ & $(0.0176)$ & $(0.0120)$ \\
\hline \multirow[t]{2}{*}{$\mathrm{ROA}_{i, t-1}$} & $0.223^{* * *}$ & $0.380^{* * *}$ & -0.0243 & $-0.205^{* * *}$ & $-0.138^{* * *}$ & $-0.327^{* * *}$ & $0.274^{* * *}$ & $0.184^{* * *}$ & $0.0111^{* *}$ & $0.00448^{* *}$ \\
\hline & $(0.0358)$ & $(0.0115)$ & $(0.0463)$ & $(0.0167)$ & $(0.0529)$ & $(0.0173)$ & $(0.0490)$ & $(0.0137)$ & $(0.00454)$ & $(0.00185)$ \\
\hline $\mathrm{NPL}_{i, t-1}$ & $0.0551^{* *}$ & $0.0944^{* * *}$ & $-0.102^{* * *}$ & $-0.138^{* * *}$ & $-0.138^{* * *}$ & $-0.188^{* * *}$ & $-0.243^{* * *}$ & $-0.294^{* * *}$ & -0.00252 & 0.000338 \\
\hline \multirow[t]{2}{*}{ GDP growth $_{t-1}$} & 0.0545 & $0.325^{* * *}$ & $0.570^{* *}$ & $0.150^{* * *}$ & -0.0483 & $0.191^{* * *}$ & $-1.141^{* * *}$ & $-1.022^{* * *}$ & -0.00496 & $-0.0745^{* * *}$ \\
\hline & $(0.203)$ & $(0.0328)$ & $(0.270)$ & $(0.0510)$ & $(0.253)$ & $(0.0515)$ & $(0.224)$ & $(0.0538)$ & $(0.0208)$ & $(0.0107)$ \\
\hline \multirow[t]{2}{*}{$M \& A_{i, t-1}$} & $0.906^{* * *}$ & $1.411^{* * *}$ & $3.032^{* * *}$ & $3.241^{* * *}$ & $2.171^{* * *}$ & $3.606^{* * *}$ & $-15.36^{* * *}$ & $-13.11^{* * *}$ & 0.0183 & $0.0178^{* * *}$ \\
\hline & $(0.112)$ & $(0.0392)$ & $(0.210)$ & $(0.0677)$ & $(0.245)$ & $(0.0778)$ & $(0.267)$ & $(0.0805)$ & $(0.0160)$ & $(0.00658)$ \\
\hline Banks fixed effect & yes & yes & yes & yes & yes & yes & yes & yes & yes & yes \\
\hline time fixed effect & yes & yes & yes & yes & yes & yes & yes & yes & yes & yes \\
\hline$\varphi_{1}+\varphi_{4}$ & 0.513 & 1.154 & 0.361 & -0.876 & -1.295 & -1.253 & -3.565 & -2.092 & -0.0317 & -0.249 \\
\hline Wald test $p$ value & 0.313 & 0.000 & 0.584 & 0.000 & 0.0438 & 0.000 & 0.000 & 0.000 & 0.563 & $1.86 \mathrm{e}-22$ \\
\hline $\mathrm{r} 2$ & 0.0770 & 0.209 & 0.115 & 0.0892 & 0.0756 & 0.130 & 0.625 & 0.542 & 0.415 & 0.525 \\
\hline $\mathrm{N}$ & 17408 & 249459 & 17181 & 248520 & 17181 & 248527 & 17408 & 249459 & 17082 & 237443 \\
\hline
\end{tabular}




\section{APPENDIX D}

TABLE 1D: Impact of market liquidity shortages according to banks liquidity level, using loans to core deposits ratio

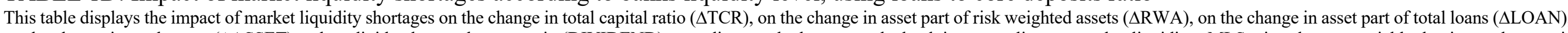

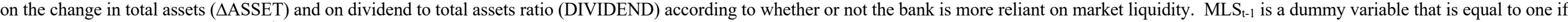

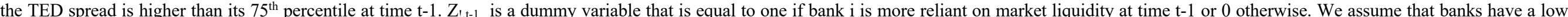

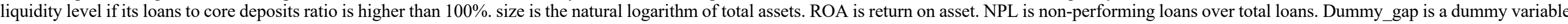

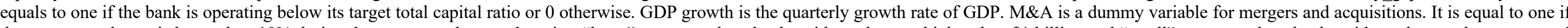

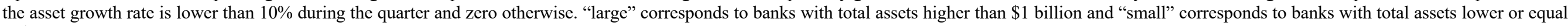
to $\$ 1$ billion. Standard errors are in parentheses. *indicate statistical significance at the $10 \%$ level. $* *$ indicate statistical significance at the $5 \%$ level. $* * *$ indicate statistical significance at the $1 \%$ level.

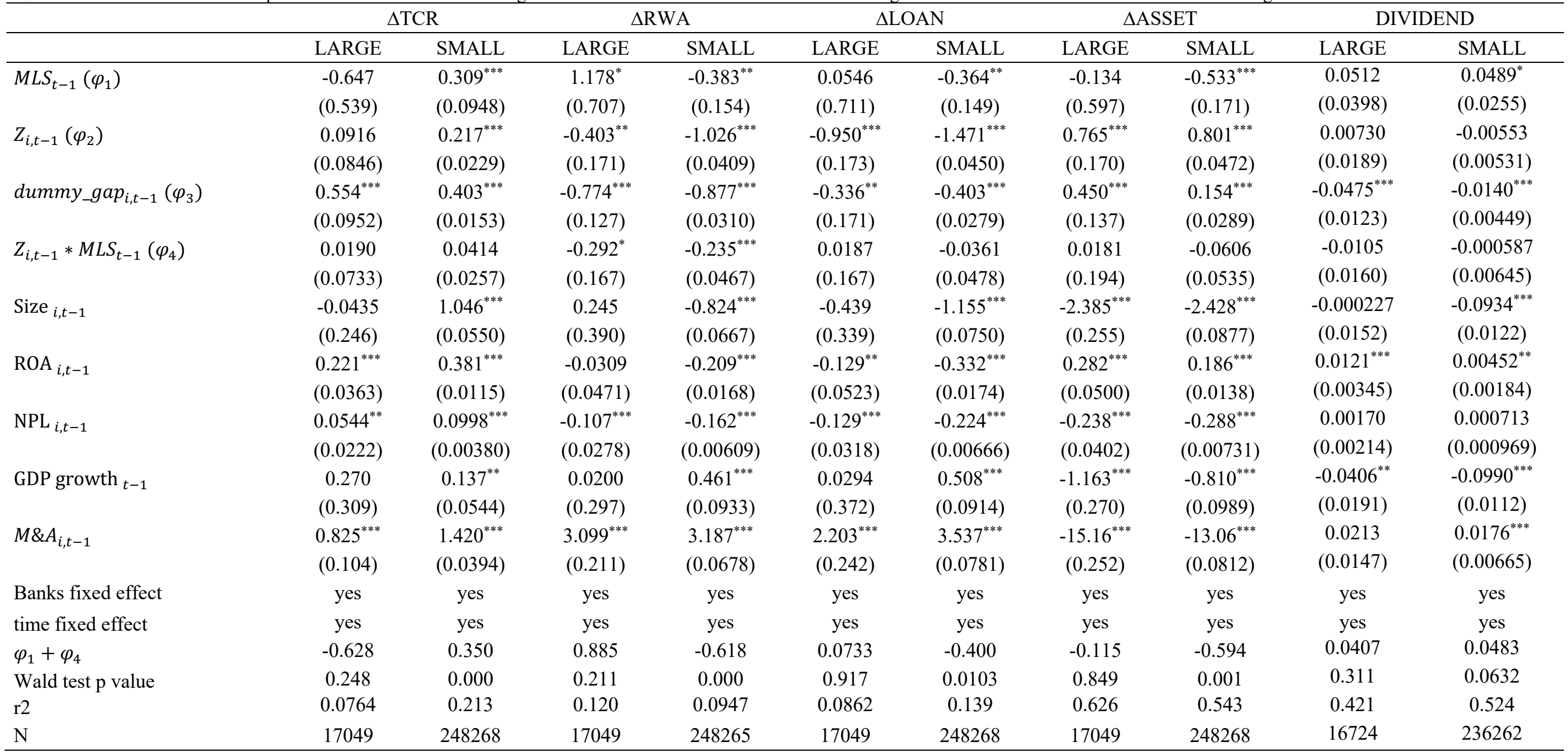


TABLE 2D: Impact of market liquidity shortages according to banks liquidity level, using liquid assets to total assets ratio

This table displays the impact of market liquidity shortages on the change in total capital ratio ( $\triangle \mathrm{TCR}$ ), on the change in asset part of risk weighted assets ( $\triangle \mathrm{RWA}$ ), on the change in asset part of total loans ( $\triangle \mathrm{LOAN}$ ), on the change in total assets ( $\triangle \mathrm{ASSET}$ ) and on dividend to total assets ratio (DIVIDEND) according to whether or not the bank is more reliant on market liquidity. MLS $\mathrm{S}_{\mathrm{t}-1}$ is a dummy variable that is equal to one if

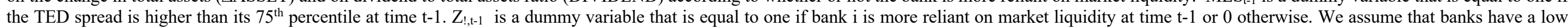

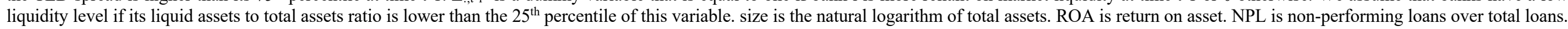

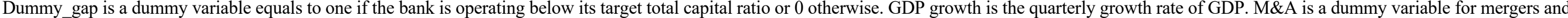

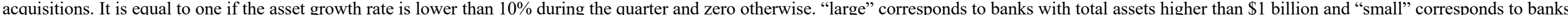

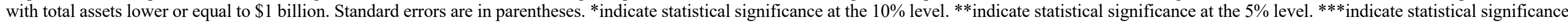
at the $1 \%$ level.

\begin{tabular}{|c|c|c|c|c|c|c|c|c|c|c|}
\hline & \multicolumn{2}{|c|}{$\triangle \mathrm{TCR}$} & \multicolumn{2}{|c|}{$\Delta \mathrm{RWA}$} & \multicolumn{2}{|c|}{$\triangle \mathrm{LOAN}$} & \multicolumn{2}{|c|}{$\triangle \mathrm{ASSET}$} & \multicolumn{2}{|c|}{ DIVIDEND } \\
\hline & LARGE & SMALL & LARGE & SMALL & LARGE & SMALL & LARGE & SMALL & LARGE & SMALL \\
\hline \multirow{2}{*}{$M L S_{t-1}\left(\varphi_{1}\right)$} & -0.460 & $0.315^{* * *}$ & $1.165^{*}$ & $-0.385^{* *}$ & -0.207 & $-0.347^{* *}$ & -0.0581 & $-0.547^{* * *}$ & $0.0717^{*}$ & $0.0488^{*}$ \\
\hline & $(0.564)$ & $(0.0960)$ & $(0.700)$ & $(0.153)$ & $(0.714)$ & $(0.148)$ & $(0.603)$ & $(0.170)$ & $(0.0421)$ & $(0.0255)$ \\
\hline \multirow[t]{2}{*}{$Z_{i, t-1}\left(\varphi_{2}\right)$} & 0.0387 & $0.0986^{* * *}$ & $-0.724^{* * *}$ & $-1.182^{* * *}$ & $-1.258^{* * *}$ & $-1.677^{* * *}$ & $0.653^{* * *}$ & $1.127^{* * *}$ & -0.00388 & -0.00203 \\
\hline & $(0.0394)$ & $(0.0140)$ & $(0.0933)$ & $(0.0297)$ & $(0.134)$ & $(0.0339)$ & $(0.116)$ & $(0.0325)$ & $(0.0110)$ & $(0.00436)$ \\
\hline \multirow[t]{2}{*}{$d u m m y \_g a p_{i, t-1}\left(\varphi_{3}\right)$} & $0.592^{* * *}$ & $0.398^{* * *}$ & $-0.756^{* * *}$ & $-0.770^{* * *}$ & -0.211 & $-0.253^{* * *}$ & $0.356^{* *}$ & 0.0442 & $-0.0493^{* * *}$ & $-0.0139^{* * *}$ \\
\hline & $(0.0973)$ & $(0.0154)$ & $(0.129)$ & $(0.0316)$ & $(0.169)$ & $(0.0283)$ & $(0.139)$ & $(0.0290)$ & $(0.0129)$ & $(0.00448)$ \\
\hline$Z_{i, t-1} * M L S_{t-1}\left(\varphi_{4}\right)$ & $(0.0602)$ & $(0.0199)$ & $(0.145)$ & $(0.0387)$ & $(0.161)$ & $(0.0388)$ & $(0.167)$ & $(0.0416)$ & $(0.0114)$ & $(0.00562)$ \\
\hline \multirow{2}{*}{ Size $_{i, t-1}$} & 0.109 & $1.065^{* * *}$ & 0.304 & $-0.848^{* * *}$ & -0.404 & $-1.172^{* * *}$ & $-2.385^{* * *}$ & $-2.433^{* * *}$ & 0.0168 & $-0.0937^{* * *}$ \\
\hline & $(0.275)$ & $(0.0552)$ & $(0.370)$ & $(0.0671)$ & $(0.323)$ & $(0.0754)$ & $(0.258)$ & $(0.0861)$ & $(0.0176)$ & $(0.0120)$ \\
\hline \multirow[t]{2}{*}{$\mathrm{ROA}_{i, t-1}$} & $0.223^{* * *}$ & $0.380^{* * *}$ & -0.0255 & $-0.199^{* * *}$ & $-0.140^{* * *}$ & $-0.320^{* * *}$ & $0.276^{* * *}$ & $0.177^{* * *}$ & $0.0110^{* *}$ & $0.00450^{* *}$ \\
\hline & $(0.0357)$ & $(0.0114)$ & $(0.0459)$ & $(0.0165)$ & $(0.0525)$ & $(0.0171)$ & $(0.0494)$ & $(0.0138)$ & $(0.00451)$ & $(0.00185)$ \\
\hline \multirow{2}{*}{$\mathrm{NPL}_{i, t-1}$} & $0.0559^{* * *}$ & $0.0982^{* * *}$ & $-0.115^{* * *}$ & $-0.159^{* * *}$ & $-0.159^{* * *}$ & $-0.220^{* * *}$ & $-0.233^{* * *}$ & $-0.290^{* * *}$ & -0.00269 & 0.000747 \\
\hline & $(0.0216)$ & $(0.00376)$ & $(0.0270)$ & $(0.00611)$ & $(0.0343)$ & $(0.00672)$ & $(0.0391)$ & $(0.00725)$ & $(0.00545)$ & $(0.000967)$ \\
\hline GDP growth $_{t-1}$ & $(0.307)$ & $(0.0544)$ & $(0.293)$ & $(0.0923)$ & $(0.367)$ & $(0.0900)$ & $(0.268)$ & $(0.0985)$ & $(0.0192)$ & $(0.0112)$ \\
\hline \multirow[t]{2}{*}{$M \& A_{i, t-1}$} & $0.909^{* * *}$ & $1.420^{* * *}$ & $3.005^{* * *}$ & $3.165^{* * *}$ & $2.126^{* * *}$ & $3.501^{* * *}$ & $-15.33^{* * *}$ & $-13.05^{* * *}$ & 0.0182 & $0.0178^{* * *}$ \\
\hline & $(0.112)$ & $(0.0393)$ & $(0.210)$ & $(0.0674)$ & $(0.245)$ & $(0.0775)$ & $(0.267)$ & $(0.0811)$ & $(0.0161)$ & $(0.00660)$ \\
\hline Banks fixed effect & yes & yes & yes & yes & yes & yes & yes & yes & yes & yes \\
\hline time fixed effect & yes & yes & yes & yes & yes & yes & yes & yes & yes & yes \\
\hline$\varphi_{1}+\varphi_{4}$ & -0.310 & 0.477 & 0.882 & -0.636 & -0.234 & -0.521 & 0.256 & -0.573 & 0.0607 & 0.0444 \\
\hline Wald test $p$ value & 0.583 & 0.000 & 0.202 & 0.000 & 0.740 & 0.001 & 0.674 & 0.001 & 0.139 & 0.0826 \\
\hline $\mathrm{r} 2$ & 0.0770 & 0.210 & 0.121 & 0.0990 & 0.0880 & 0.150 & 0.627 & 0.546 & 0.415 & 0.525 \\
\hline $\mathrm{N}$ & 17408 & 249454 & 17181 & 248519 & 17181 & 248522 & 17408 & 249454 & 17082 & 237438 \\
\hline
\end{tabular}


TABLE 3D: Impact of market liquidity shortages according to banks liquidity level, using the reliance on wholesale funding

This table displays the impact of market liquidity shortages on the change in total capital ratio ( $\triangle \mathrm{TCR})$, on the change in asset part of risk weighted assets ( $\triangle \mathrm{RWA})$, on the change in asset part of total loans ( $\triangle \mathrm{LOAN}$ ), on the change in total assets ( $\triangle \mathrm{ASSET}$ ) and on dividend to total assets ratio (DIVIDEND) according to whether or not the bank is more reliant on market liquidity. MLS $\mathrm{S}_{\mathrm{t}-1}$ is a dummy variable that is equal to one if

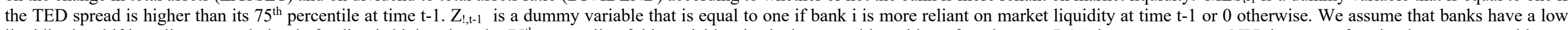

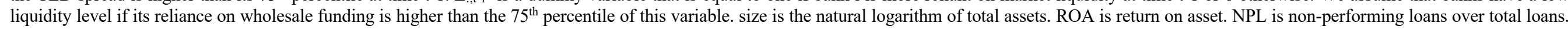

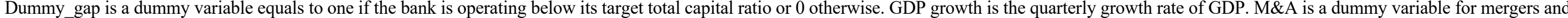

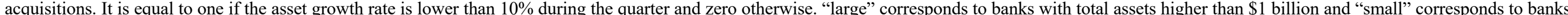

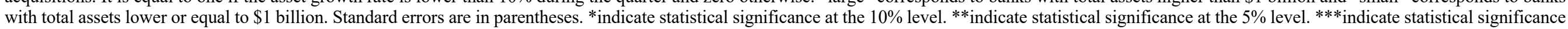
with total assets
at the $1 \%$ level.

\begin{tabular}{|c|c|c|c|c|c|c|c|c|c|c|}
\hline & \multicolumn{2}{|c|}{$\Delta \mathrm{TCR}$} & \multicolumn{2}{|c|}{$\Delta \mathrm{RWA}$} & \multicolumn{2}{|c|}{$\triangle \mathrm{LOAN}$} & \multicolumn{2}{|c|}{$\triangle \mathrm{ASSET}$} & \multicolumn{2}{|c|}{ DIVIDEND } \\
\hline & LARGE & SMALL & LARGE & SMALL & LARGE & SMALL & LARGE & SMALL & LARGE & SMALL \\
\hline \multirow{2}{*}{$M L S_{t-1}\left(\varphi_{1}\right)$} & -0.397 & $0.341^{* * *}$ & 1.021 & $-0.512^{* * *}$ & -0.188 & $-0.510^{* * *}$ & 0.0384 & $-0.431^{* *}$ & $0.0726^{*}$ & $0.0500^{*}$ \\
\hline & $(0.572)$ & $(0.0960)$ & $(0.712)$ & $(0.155)$ & $(0.729)$ & $(0.150)$ & $(0.609)$ & $(0.171)$ & $(0.0434)$ & $(0.0255)$ \\
\hline \multirow{2}{*}{$Z_{i, t-1}\left(\varphi_{2}\right)$} & -0.0261 & 0.0261 & $0.198^{* *}$ & $-0.236^{* * *}$ & 0.175 & $-0.310^{* * *}$ & -0.195 & -0.0378 & 0.00383 & -0.00669 \\
\hline & $(0.0647)$ & $(0.0204)$ & $(0.0987)$ & $(0.0330)$ & $(0.122)$ & $(0.0363)$ & $(0.125)$ & $(0.0405)$ & $(0.0114)$ & $(0.00543)$ \\
\hline \multirow{2}{*}{$d u m m y_{-} g a p_{i, t-1}\left(\varphi_{3}\right)$} & $0.593^{* * *}$ & $0.414^{* * *}$ & $-0.869^{* * *}$ & $-0.926^{* * *}$ & $-0.390^{* *}$ & $-0.470^{* * *}$ & $0.460^{* * *}$ & $0.198^{* * *}$ & $-0.0508^{* * *}$ & $-0.0141^{* * *}$ \\
\hline & $(0.0964)$ & $(0.0155)$ & $(0.129)$ & $(0.0308)$ & $(0.167)$ & $(0.0276)$ & $(0.140)$ & $(0.0291)$ & $(0.0128)$ & $(0.00449)$ \\
\hline \multirow{2}{*}{$Z_{i, t-1} * M L S_{t-1}\left(\varphi_{4}\right)$} & 0.00974 & $0.0993^{* * *}$ & -0.0299 & $-0.226^{* * *}$ & -0.118 & $-0.233^{* * *}$ & 0.120 & $0.134^{* * *}$ & -0.00999 & -0.00659 \\
\hline & $(0.0542)$ & $(0.0240)$ & $(0.143)$ & $(0.0419)$ & $(0.144)$ & $(0.0402)$ & $(0.172)$ & $(0.0464)$ & $(0.0124)$ & $(0.00583)$ \\
\hline \multirow{2}{*}{ Size $_{i, t-1}$} & 0.122 & $1.075^{* * *}$ & 0.254 & $-0.932^{* * *}$ & -0.464 & $-1.295^{* * *}$ & $-2.328^{* * *}$ & $-2.310^{* * *}$ & 0.0156 & $-0.0924^{* * *}$ \\
\hline & $(0.277)$ & $(0.0559)$ & $(0.372)$ & $(0.0678)$ & $(0.326)$ & $(0.0764)$ & $(0.249)$ & $(0.0863)$ & $(0.0182)$ & $(0.0122)$ \\
\hline \multirow{2}{*}{$\mathrm{ROA}_{i, t-1}$} & $0.223^{* * *}$ & $0.380^{* * *}$ & -0.0229 & $-0.210^{* * *}$ & $-0.140^{* * *}$ & $-0.334^{* * *}$ & $0.273^{* * *}$ & $0.186^{* * *}$ & $0.0111^{* *}$ & $0.00443^{* *}$ \\
\hline & $(0.0360)$ & $(0.0115)$ & $(0.0463)$ & $(0.0167)$ & $(0.0530)$ & $(0.0173)$ & $(0.0495)$ & $(0.0138)$ & $(0.00453)$ & $(0.00185)$ \\
\hline $\mathrm{NPL}_{i, t-1}$ & $0.0539^{* *}$ & $0.0977^{* * *}$ & $-0.104^{* * *}$ & $-0.154^{* * *}$ & $-0.143^{* * *}$ & $-0.212^{* * *}$ & $-0.241^{* * *}$ & $-0.294^{* * *}$ & -0.00259 & 0.000749 \\
\hline \multirow[t]{2}{*}{ GDP growth $_{t-1}$} & 0.268 & $0.137^{* *}$ & 0.0263 & $0.459^{* * *}$ & 0.0797 & $0.507^{* * *}$ & $-1.174^{* * *}$ & $-0.809^{* * *}$ & $-0.0396^{* *}$ & $-0.0990^{* * *}$ \\
\hline & $(0.307)$ & $(0.0544)$ & $(0.297)$ & $(0.0934)$ & $(0.373)$ & $(0.0916)$ & $(0.270)$ & $(0.0989)$ & $(0.0192)$ & $(0.0112)$ \\
\hline \multirow[t]{2}{*}{$M \& A_{i, t-1}$} & $0.902^{* * *}$ & $1.409^{* * *}$ & $3.034^{* * *}$ & $3.233^{* * *}$ & $2.171^{* * *}$ & $3.596^{* * *}$ & $-15.36^{* * *}$ & $-13.11^{* * *}$ & 0.0191 & $0.0181^{* * *}$ \\
\hline & $(0.113)$ & $(0.0393)$ & $(0.210)$ & $(0.0677)$ & $(0.245)$ & $(0.0779)$ & $(0.268)$ & $(0.0808)$ & $(0.0162)$ & $(0.00662)$ \\
\hline Banks fixed effect & yes & yes & yes & yes & yes & yes & yes & yes & yes & yes \\
\hline time fixed effect & yes & yes & yes & yes & yes & yes & yes & yes & yes & yes \\
\hline$\varphi_{1}+\varphi_{4}$ & -0.387 & 0.441 & 0.991 & -0.738 & -0.306 & -0.743 & 0.158 & -0.297 & 0.0626 & 0.0434 \\
\hline Wald test $p$ value & 0.486 & 0.000 & 0.152 & 0.000 & 0.664 & 0.000 & 0.795 & 0.0903 & 0.133 & 0.0893 \\
\hline $\mathrm{r} 2$ & 0.0768 & 0.209 & 0.116 & 0.0893 & 0.0753 & 0.130 & 0.626 & 0.542 & 0.415 & 0.524 \\
\hline $\mathrm{N}$ & 17181 & 248482 & 17181 & 248475 & 17181 & 248482 & 17181 & 248482 & 16856 & 236473 \\
\hline
\end{tabular}




\section{APPENDIX E}

TABLE 1E: Impact of market liquidity shortages (using the sample of "real commercial banks") according to banks liquidity level

Depending on whether or not the bank is more reliant on market liquidity, this table displays the impact of market liquidity shortages on the change in total capital ratio ( $\triangle \mathrm{TCR}$ ), on the change in asset part of risk

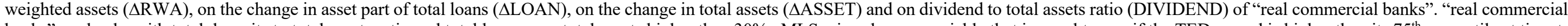

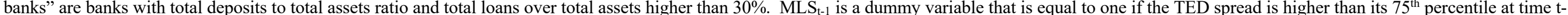

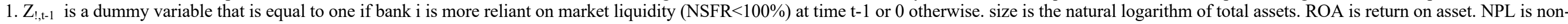

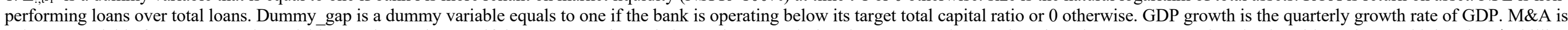

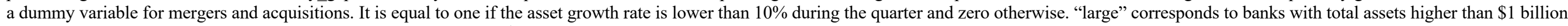

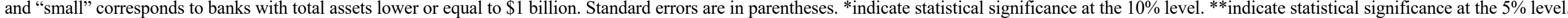
***indicate statistical significance at the $1 \%$ level.

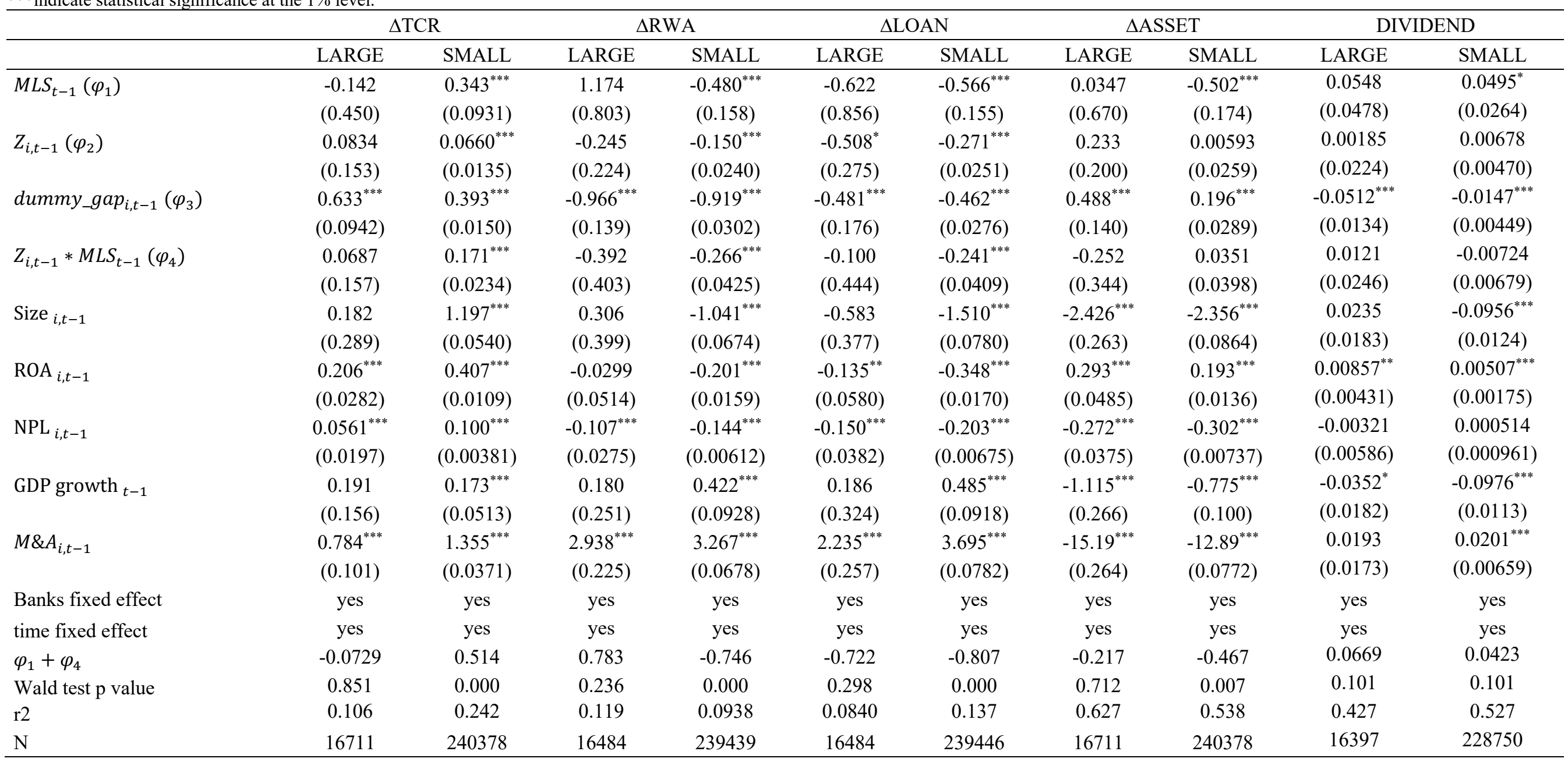


TABLE 2E: Impact of market liquidity shortages (using the sample of "real commercial banks") according to gap between actual and target capital

Depending on whether or not the bank is operating below its target total capital ratio, this table displays the impact of market liquidity shortages on the change in total capital ratio ( $\triangle \mathrm{TCR})$, on the change in asset part of risk weighted assets ( $\triangle \mathrm{RWA}$ ), on the change in asset part of total loans ( $\triangle \mathrm{LOAN})$, on the change in total assets ( $\triangle \mathrm{ASSET}$ ) and on dividend to total assets ratio (DIVIDEND) of "real commercial banks". "real commercial banks" are banks with total deposits to total assets ratio and total loans over total assets higher than $30 \%$. $\mathrm{MLS}_{\mathrm{t}-1}$ is a dummy variable that is equal to one if the TED spread is higher than its $75^{\text {th }}$ percentile at time t-1. $Z_{!, t-1}$ is a dummy variable that is equal to one if bank $\mathrm{i}$ is more reliant on market liquidity (NSFR $<100 \%$ ) at time t-1 or 0 otherwise. size is the natural logarithm of total assets. ROA is return on asset. NPL is non-performing loans over total loans. Dummy gap is a dummy variable equals to one if the bank is operating below its target total capital ratio or 0 otherwise. GDP growth is the quarterly growth rate of GDP.

M\&A is a dummy variable for mergers and acquisitions. It is equal to one if the asset growth rate is lower than $10 \%$ during the quarter and zero otherwise. "large" corresponds to banks with total assets higher than $\$ 1$ billion and "small" corresponds to banks with total assets lower or equal to $\$ 1$ billion. Standard errors are in parentheses. *indicate statistical significance at the $10 \%$ level. **indicate statistical significance at the $5 \%$ level. ***indicate statistical significance at the $1 \%$ level.

\begin{tabular}{|c|c|c|c|c|c|c|c|c|c|c|}
\hline & \multicolumn{2}{|c|}{$\triangle \mathrm{TCR}$} & \multicolumn{2}{|c|}{$\Delta \mathrm{RWA}$} & \multicolumn{2}{|c|}{$\triangle \mathrm{LOAN}$} & \multicolumn{2}{|c|}{$\triangle \mathrm{ASSET}$} & \multicolumn{2}{|c|}{ DIVIDEND } \\
\hline & LARGE & SMALL & LARGE & SMALL & LARGE & SMALL & LARGE & SMALL & LARGE & SMALL \\
\hline \multirow[t]{2}{*}{$M L S_{t-1}\left(\omega_{1}\right)$} & -0.276 & $0.404^{* * *}$ & 1.019 & $-0.559^{* * *}$ & -0.737 & $-0.664^{* * *}$ & -0.271 & $-0.483^{* * *}$ & 0.0675 & $0.0469^{*}$ \\
\hline & $(0.385)$ & $(0.0919)$ & $(0.650)$ & $(0.157)$ & $(0.721)$ & $(0.153)$ & $(0.621)$ & $(0.173)$ & $(0.0414)$ & $(0.0261)$ \\
\hline \multirow[t]{2}{*}{$Z_{i, t-1}\left(\omega_{2}\right)$} & 0.0961 & $0.109^{* * *}$ & -0.325 & $-0.216^{* * *}$ & $-0.529^{* *}$ & $-0.331^{* * *}$ & 0.181 & 0.0146 & 0.00422 & 0.00527 \\
\hline & $(0.133)$ & $(0.0127)$ & $(0.216)$ & $(0.0228)$ & $(0.262)$ & $(0.0238)$ & $(0.181)$ & $(0.0241)$ & $(0.0201)$ & $(0.00435)$ \\
\hline \multirow[t]{2}{*}{$d u m m y \_g a p_{i, t-1}\left(\omega_{3}\right)$} & $0.576^{* * *}$ & $0.359^{* * *}$ & $-0.908^{* * *}$ & $-0.853^{* * *}$ & $-0.488^{* * *}$ & $-0.426^{* * *}$ & $0.465^{* * *}$ & $0.195^{* * *}$ & $-0.0507^{* * *}$ & $-0.0137^{* * *}$ \\
\hline & $(0.107)$ & $(0.0159)$ & $(0.162)$ & $(0.0312)$ & $(0.180)$ & $(0.0289)$ & $(0.143)$ & $(0.0302)$ & $(0.0151)$ & $(0.00477)$ \\
\hline$d u m m y_{-} g a p_{i, t-1} * M L S_{t-1}\left(\omega_{4}\right)$ & $(0.173)$ & $(0.0173)$ & $(0.282)$ & $(0.0365)$ & $(0.318)$ & $(0.0344)$ & $(0.258)$ & $(0.0382)$ & $(0.0259)$ & $(0.00573)$ \\
\hline \multirow{2}{*}{$\operatorname{Size}_{i, t-1}$} & 0.183 & $1.198^{* * *}$ & 0.306 & $-1.042^{* * *}$ & -0.582 & $-1.514^{* * *}$ & $-2.425^{* * *}$ & $-2.355^{* * *}$ & 0.0235 & $-0.0956^{* * *}$ \\
\hline & $(0.290)$ & $(0.0540)$ & $(0.400)$ & $(0.0674)$ & $(0.377)$ & $(0.0781)$ & $(0.263)$ & $(0.0865)$ & $(0.0183)$ & $(0.0124)$ \\
\hline \multirow{2}{*}{$\mathrm{ROA}_{i, t-1}$} & $0.206^{* * *}$ & $0.407^{* * *}$ & -0.0292 & $-0.201^{* * *}$ & $-0.135^{* *}$ & $-0.347^{* * *}$ & $0.293^{* * *}$ & $0.193^{* * *}$ & $0.00857^{* *}$ & $0.00508^{* * *}$ \\
\hline & $(0.0281)$ & $(0.0109)$ & $(0.0512)$ & $(0.0159)$ & $(0.0581)$ & $(0.0170)$ & $(0.0485)$ & $(0.0137)$ & $(0.00430)$ & $(0.00175)$ \\
\hline \multirow{2}{*}{$\mathrm{NPL}_{i, t-1}$} & $0.0554^{* * *}$ & $0.0998^{* * *}$ & $-0.107^{* * *}$ & $-0.143^{* * *}$ & $-0.150^{* * *}$ & $-0.202^{* * *}$ & $-0.272^{* * *}$ & $-0.302^{* * *}$ & -0.00321 & 0.000541 \\
\hline & $(0.0197)$ & $(0.00380)$ & $(0.0277)$ & $(0.00608)$ & $(0.0385)$ & $(0.00673)$ & $(0.0377)$ & $(0.00737)$ & $(0.00584)$ & $(0.000962)$ \\
\hline GDP growth $_{t-1}$ & $(0.156)$ & $(0.0513)$ & $(0.251)$ & $(0.0928)$ & $(0.323)$ & $(0.0918)$ & $(0.266)$ & $(0.100)$ & $(0.0182)$ & $(0.0113)$ \\
\hline \multirow[t]{2}{*}{$M \& A_{i, t-1}$} & $0.784^{* * *}$ & $1.354^{* * *}$ & $2.938^{* * *}$ & $3.268^{* * *}$ & $2.235^{* * *}$ & $3.695^{* * *}$ & $-15.19^{* * *}$ & $-12.89^{* * *}$ & 0.0193 & $0.0200^{* * *}$ \\
\hline & $(0.100)$ & $(0.0371)$ & $(0.225)$ & $(0.0678)$ & $(0.257)$ & $(0.0782)$ & $(0.264)$ & $(0.0772)$ & $(0.0173)$ & $(0.00659)$ \\
\hline Banks fixed effect & yes & yes & yes & yes & yes & yes & yes & yes & yes & yes \\
\hline time fixed effect & yes & yes & yes & yes & yes & yes & yes & yes & yes & yes \\
\hline$\omega_{1}+\omega_{4}$ & -0.0289 & 0.544 & 0.766 & -0.833 & -0.707 & -0.816 & -0.175 & -0.480 & 0.0652 & 0.0424 \\
\hline Wald test $p$ value & 0.942 & 0.000 & 0.260 & 0.000 & 0.317 & 0.000 & 0.766 & 0.006 & 0.124 & 0.0972 \\
\hline $\mathrm{r} 2$ & 0.107 & 0.242 & 0.119 & 0.0938 & 0.0840 & 0.137 & 0.627 & 0.538 & 0.427 & 0.527 \\
\hline $\mathrm{N}$ & 16711 & 240378 & 16484 & 239439 & 16484 & 239446 & 16711 & 240378 & 16397 & 228750 \\
\hline
\end{tabular}




\section{APPENDIX F}

Table 1F: Impact of market liquidity shortages in normal time according to bank liquidity level

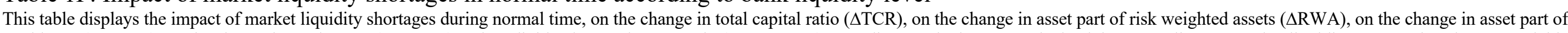

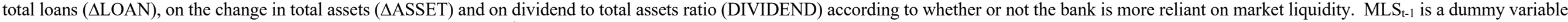

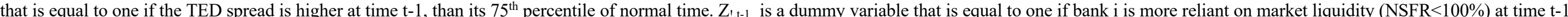

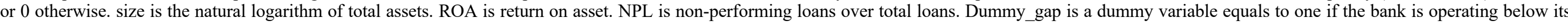

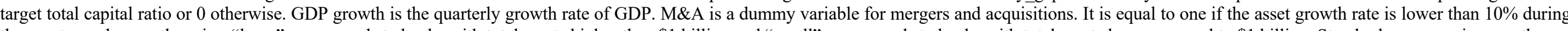

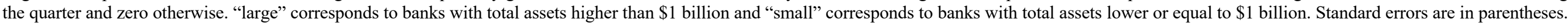
*indicate statistical significance at the $10 \%$ level. $* *$ indicate statistical significance at the $5 \%$ level. ***indicate statistical significance at the $1 \%$ level.

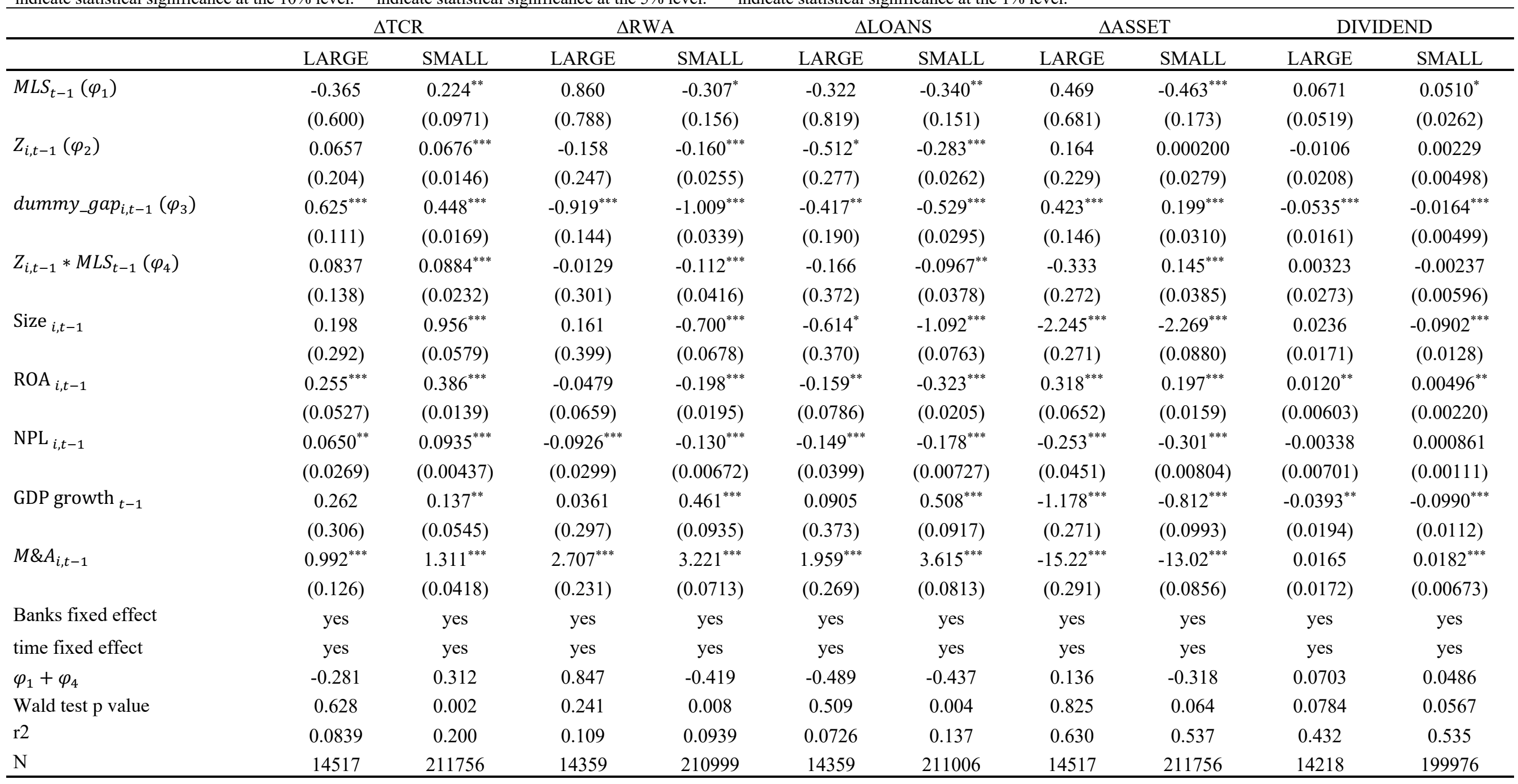


Table 2F: Impact of market liquidity shortages in normal time according to gap between actual and target capital

This table displays the impact of market liquidity shortages during normal time, on the change in total capital ratio $(\triangle \mathrm{TCR})$, on the change in asset part of risk weighted assets ( $\triangle \mathrm{RWA}$ ), on the change in asset part of total loans $(\triangle \mathrm{LOAN})$, on the change in total assets $(\triangle \mathrm{ASSET})$ and on dividend to total assets ratio (DIVIDEND) according to whether or not the bank is operating below its target total capital ratio. MLS $\mathrm{T}_{\mathrm{t}-1}$ is a dummy variable that is equal to one if the TED spread is higher at time $t-1$, than its $75^{\text {th }}$ percentile of normal time. $Z_{t, t-1}$ is a dummy variable that is equal to one if bank $i$ is more reliant on market liquidity $(\mathrm{NSFR}<100 \%)$ at time $\mathrm{t}-1$ or 0 otherwise. size is the natural logarithm of total assets. ROA is return on asset. NPL is non-performing loans over total loans. Dummy gap is a dummy variable equals to one if the bank is operating below its target total capital ratio or 0 otherwise. GDP growth is the quarterly growth rate of GDP. M\&A is a dummy variable for mergers and acquisitions. It is equal to one if the asset growth rate is lower than 10\% during the quarter and zero otherwise. "large" corresponds to banks with total assets higher than $\$ 1$ billion and "small" corresponds to banks with total assets lower or equal to $\$ 1$ billion. Standard errors are in parentheses. *indicte statistical significance at the $10 \%$ level. **indicate statistical significance at the $5 \%$ level ***indicate statistical significance at the $1 \%$ level.

\begin{tabular}{|c|c|c|c|c|c|c|c|c|c|c|}
\hline \multicolumn{3}{|c|}{$\Delta \mathrm{TCR}$} & \multicolumn{2}{|l|}{$\Delta \mathrm{RWA}$} & \multicolumn{2}{|l|}{$\triangle \mathrm{LOANS}$} & \multicolumn{2}{|l|}{$\triangle \mathrm{ASSET}$} & \multicolumn{2}{|c|}{ DIVIDEND } \\
\hline LARGE & \multicolumn{2}{|c|}{ SMALL } & $\begin{array}{ll}\text { LARGE } \quad \mathrm{S} \\
\end{array}$ & SMALL & LARGE & SMALL & LARGE $\quad S$ & SMALL & LARGE & \multirow{3}{*}{$\begin{array}{c}\text { SMALL } \\
0.0477^{*} \\
(0.0258)\end{array}$} \\
\hline$M L S_{t-1}\left(\omega_{1}\right)$ & -0.415 & $0.237^{* *}$ & 0.992 & $-0.308^{* *}$ & -0.351 & $-0.386^{* *}$ & 0.251 & $-0.360^{* *}$ & 0.0771 & \\
\hline & $(0.578)$ & $(0.0965)$ & $(0.733)$ & $(0.155)$ & $(0.760)$ & $(0.150)$ & $(0.623)$ & $(0.171)$ & $(0.0472)$ & \\
\hline \multirow[t]{2}{*}{$Z_{i, t-1}\left(\omega_{2}\right)$} & 0.0877 & $0.0924^{* * *}$ & -0.159 & $-0.191^{* * *}$ & $-0.559^{* *}$ & $-0.311^{* * *}$ & 0.0698 & $0.0428^{*}$ & -0.00957 & 0.00167 \\
\hline & $(0.177)$ & $(0.0140)$ & $(0.223)$ & $(0.0245)$ & $(0.263)$ & $(0.0244)$ & $(0.204)$ & $(0.0259)$ & $(0.0186)$ & $(0.00467)$ \\
\hline \multirow[t]{2}{*}{$d u m m y_{-} g a p_{i, t-1}\left(\omega_{3}\right)$} & $0.588^{* * *}$ & $0.406^{* * *}$ & $-0.878^{* * *}$ & $-0.936^{* * *}$ & $-0.382^{* *}$ & $-0.522^{* * *}$ & $0.449^{* * *}$ & $0.232^{* * *}$ & $-0.0515^{* * *}$ & $-0.0182^{* * *}$ \\
\hline & $(0.116)$ & $(0.0174)$ & $(0.150)$ & $(0.0340)$ & $(0.192)$ & $(0.0310)$ & $(0.152)$ & $(0.0325)$ & $(0.0171)$ & $(0.00521)$ \\
\hline \multirow[t]{2}{*}{$d u m m y_{-} g a p_{i, t-1} * M L S_{t-1}\left(\omega_{4}\right)$} & 0.166 & $0.164^{* * *}$ & -0.192 & $-0.281^{* * *}$ & -0.159 & -0.0273 & -0.106 & $-0.125^{* * *}$ & -0.00976 & 0.00791 \\
\hline & $(0.157)$ & $(0.0191)$ & $(0.207)$ & $(0.0398)$ & $(0.317)$ & $(0.0350)$ & $(0.229)$ & $(0.0387)$ & $(0.0238)$ & $(0.00534)$ \\
\hline \multirow[t]{2}{*}{ Size $_{i, t-1}$} & 0.201 & $0.960^{* * *}$ & 0.157 & $-0.706^{* * *}$ & $-0.616^{*}$ & $-1.093^{* * *}$ & $-2.244^{* * *}$ & $-2.271^{* * *}$ & 0.0234 & $-0.0902^{* * *}$ \\
\hline & $(0.293)$ & $(0.0579)$ & $(0.400)$ & $(0.0677)$ & $(0.371)$ & $(0.0764)$ & $(0.272)$ & $(0.0880)$ & $(0.0171)$ & $(0.0128)$ \\
\hline \multirow[t]{2}{*}{$\mathrm{ROA}_{i, t-1}$} & $0.255^{* * *}$ & $0.386^{* * *}$ & -0.0471 & $-0.198^{* * *}$ & $-0.158^{* *}$ & $-0.323^{* * *}$ & $0.319^{* * *}$ & $0.197^{* * *}$ & $0.0120^{* *}$ & $0.00495^{* *}$ \\
\hline & $(0.0526)$ & $(0.0138)$ & $(0.0657)$ & $(0.0195)$ & $(0.0786)$ & $(0.0205)$ & $(0.0651)$ & $(0.0159)$ & $(0.00608)$ & $(0.00220)$ \\
\hline \multirow[t]{2}{*}{$\mathrm{NPL}_{i, t-1}$} & $0.0647^{* *}$ & $0.0936^{* * *}$ & $-0.0924^{* * *}$ & $-0.130^{* * *}$ & $-0.149^{* * *}$ & $-0.177^{* * *}$ & $-0.252^{* * *}$ & $-0.303^{* * *}$ & -0.00337 & 0.000906 \\
\hline & $(0.0269)$ & $(0.00436)$ & $(0.0299)$ & $(0.00671)$ & $(0.0397)$ & $(0.00727)$ & $(0.0452)$ & $(0.00804)$ & $(0.00702)$ & $(0.00111)$ \\
\hline \multirow[t]{2}{*}{ GDP growth $_{t-1}$} & 0.262 & $0.137^{* *}$ & 0.0358 & $0.460^{* * *}$ & 0.0906 & $0.508^{* * *}$ & $-1.178^{* * *}$ & $-0.812^{* * *}$ & $-0.0393^{* *}$ & $-0.0989^{* * *}$ \\
\hline & $(0.306)$ & $(0.0545)$ & $(0.297)$ & $(0.0935)$ & $(0.373)$ & $(0.0917)$ & $(0.271)$ & $(0.0993)$ & $(0.0194)$ & $(0.0112)$ \\
\hline \multirow[t]{2}{*}{$M \& A_{i, t-1}$} & $0.991^{* * *}$ & $1.310^{* * *}$ & $2.709^{* * *}$ & $3.223^{* * *}$ & $1.960^{* * *}$ & $3.615^{* * *}$ & $-15.22^{* * *}$ & $-13.02^{* * *}$ & 0.0165 & $0.0181^{* * *}$ \\
\hline & $(0.127)$ & $(0.0418)$ & $(0.231)$ & $(0.0712)$ & $(0.269)$ & $(0.0813)$ & $(0.291)$ & $(0.0856)$ & $(0.0172)$ & $(0.00673)$ \\
\hline Banks fixed effect & yes & yes & yes & yes & yes & yes & yes & yes & yes & yes \\
\hline time fixed effect & yes & yes & yes & yes & yes & yes & yes & yes & yes & yes \\
\hline$\omega_{1}+\omega_{4}$ & -0.249 & 0.401 & 0.800 & -0.590 & -0.511 & -0.413 & 0.146 & -0.485 & 0.0673 & 0.0556 \\
\hline Wald test $\mathrm{p}$ value & 0.672 & 0.000 & 0.271 & 0.000 & 0.495 & 0.007 & 0.816 & 0.005 & 0.0904 & 0.0308 \\
\hline r2 & 0.0840 & 0.200 & 0.109 & 0.0941 & 0.0727 & 0.137 & 0.630 & 0.537 & 0.432 & 0.535 \\
\hline $\mathrm{N}$ & 14517 & 211756 & 14359 & 210999 & 14359 & 211006 & 14517 & 211756 & 14418 & 210430 \\
\hline
\end{tabular}


Table 3F: Impact of severe market liquidity shortages $\left(90^{\text {th }}\right.$ percentile) in normal time according to bank liquidity level

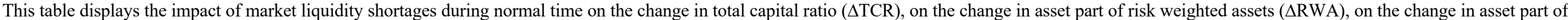

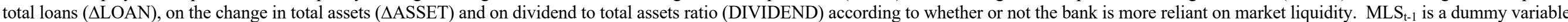

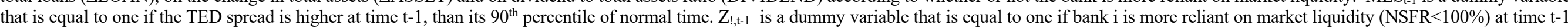

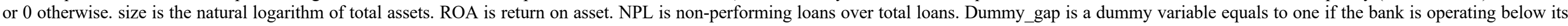

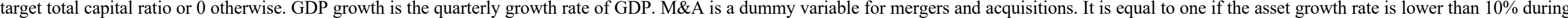

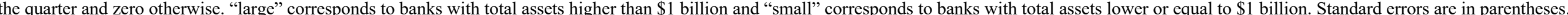
*indicate statistical significance at the $10 \%$ level. **indicate statistical significance at the $5 \%$ level. ***indicate statistical significance at the $1 \%$ level.

\begin{tabular}{|c|c|c|c|c|c|c|c|c|c|c|}
\hline & \multicolumn{2}{|c|}{$\triangle \mathrm{TCR}$} & \multicolumn{2}{|c|}{$\Delta \mathrm{RWA}$} & \multicolumn{2}{|c|}{$\triangle \mathrm{LOANS}$} & \multicolumn{2}{|c|}{$\triangle \mathrm{ASSET}$} & \multicolumn{2}{|c|}{ DIVIDEND } \\
\hline & LARGE & SMALL & LARGE & SMALL & LARGE & SMALL & LARGE & SMALL & LARGE & SMALL \\
\hline \multirow[t]{2}{*}{$M L S_{t-1}\left(\varphi_{1}\right)$} & -0.294 & $0.192^{*}$ & $2.175^{* *}$ & $-0.290^{*}$ & 0.640 & $-0.323^{* *}$ & 0.165 & $-0.436^{* *}$ & 0.132 & $0.0624^{* *}$ \\
\hline & $(0.613)$ & $(0.0982)$ & $(1.045)$ & $(0.160)$ & $(1.021)$ & $(0.152)$ & $(0.823)$ & $(0.174)$ & $(0.0892)$ & $(0.0270)$ \\
\hline \multirow[t]{2}{*}{$Z_{i, t-1}\left(\varphi_{2}\right)$} & 0.0896 & $0.0752^{* * *}$ & -0.0518 & $-0.175^{* * *}$ & $-0.469^{*}$ & $-0.295^{* * *}$ & 0.0679 & 0.0307 & -0.00555 & 0.00328 \\
\hline & $(0.180)$ & $(0.0143)$ & $(0.220)$ & $(0.0250)$ & $(0.267)$ & $(0.0251)$ & $(0.207)$ & $(0.0267)$ & $(0.0182)$ & $(0.00474)$ \\
\hline$d u m m y_{-} g a p_{i, t-1}\left(\varphi_{3}\right)$ & $0.624^{* * *}$ & $0.448^{* * *}$ & $-0.916^{* * *}$ & $-1.009^{* * *}$ & $-0.413^{* *}$ & $-0.529^{* * *}$ & $0.426^{* * *}$ & $0.199^{* * *}$ & $-0.0534^{* * *}$ & $-0.0164^{* * *}$ \\
\hline \multirow[t]{2}{*}{$Z_{i, t-1} * M L S_{t-1}\left(\varphi_{4}\right)$} & 0.00365 & $0.157^{* * *}$ & $-1.505^{* *}$ & $-0.150^{* *}$ & $-1.260^{*}$ & $-0.135^{* *}$ & 0.00825 & $0.0998^{*}$ & -0.0701 & $-0.0256^{*}$ \\
\hline & $(0.166)$ & $(0.0380)$ & $(0.733)$ & $(0.0706)$ & $(0.718)$ & $(0.0527)$ & $(0.585)$ & $(0.0578)$ & $(0.0820)$ & $(0.0131)$ \\
\hline \multirow[t]{2}{*}{ Size $_{i, t-1}$} & 0.197 & $0.957^{* * *}$ & 0.153 & $-0.701^{* * *}$ & $-0.619^{*}$ & $-1.093^{* * *}$ & $-2.242^{* * *}$ & $-2.268^{* * *}$ & 0.0232 & $-0.0903^{* * *}$ \\
\hline & $(0.293)$ & $(0.0579)$ & $(0.399)$ & $(0.0678)$ & $(0.370)$ & $(0.0763)$ & $(0.271)$ & $(0.0879)$ & $(0.0171)$ & $(0.0128)$ \\
\hline \multirow[t]{2}{*}{$\mathrm{ROA}_{i, t-1}$} & $0.255^{* * *}$ & $0.386^{* * *}$ & -0.0502 & $-0.198^{* * *}$ & $-0.161^{* *}$ & $-0.323^{* * *}$ & $0.319^{* * *}$ & $0.197^{* * *}$ & $0.0119^{* *}$ & $0.00496^{* *}$ \\
\hline & $(0.0527)$ & $(0.0139)$ & $(0.0660)$ & $(0.0195)$ & $(0.0786)$ & $(0.0205)$ & $(0.0652)$ & $(0.0159)$ & $(0.00596)$ & $(0.00220)$ \\
\hline $\mathrm{NPL}_{i, t-1}$ & $(0.0269)$ & $(0.00437)$ & $(0.0298)$ & $(0.00672)$ & $(0.0397)$ & $(0.00726)$ & $(0.0452)$ & $(0.00804)$ & $(0.00700)$ & $(0.00111)$ \\
\hline \multirow[t]{2}{*}{ GDP growth $_{t-1}$} & 0.262 & $0.137^{* *}$ & 0.0353 & $0.461^{* * *}$ & 0.0901 & $0.508^{* * *}$ & $-1.178^{* * *}$ & $-0.812^{* * *}$ & $-0.0394^{* *}$ & $-0.0990^{* * *}$ \\
\hline & $(0.306)$ & $(0.0545)$ & $(0.297)$ & $(0.0935)$ & $(0.373)$ & $(0.0917)$ & $(0.271)$ & $(0.0993)$ & $(0.0194)$ & $(0.0112)$ \\
\hline \multirow[t]{2}{*}{$M \& A_{i, t-1}$} & $0.993^{* * *}$ & $1.311^{* * *}$ & $2.717^{* * *}$ & $3.221^{* * *}$ & $1.967^{* * *}$ & $3.615^{* * *}$ & $-15.22^{* * *}$ & $-13.02^{* * *}$ & 0.0168 & $0.0183^{* * *}$ \\
\hline & $(0.127)$ & $(0.0418)$ & $(0.230)$ & $(0.0713)$ & $(0.269)$ & $(0.0813)$ & $(0.291)$ & $(0.0856)$ & $(0.0172)$ & $(0.00673)$ \\
\hline Banks fixed effect & yes & yes & yes & yes & yes & yes & yes & yes & yes & yes \\
\hline time fixed effect & yes & yes & yes & yes & yes & yes & yes & yes & yes & yes \\
\hline$\varphi_{1}+\varphi_{4}$ & -0.290 & 0.349 & 0.671 & -0.441 & -0.619 & -0.458 & 0.173 & -0.336 & 0.0615 & 0.0368 \\
\hline Wald test $\mathrm{p}$ value & 0.617 & 0.000 & 0.349 & 0.005 & 0.400 & 0.003 & 0.779 & 0.053 & 0.121 & 0.156 \\
\hline $\mathrm{r} 2$ & 0.0838 & 0.200 & 0.110 & 0.0939 & 0.0732 & 0.137 & 0.630 & 0.537 & 0.433 & 0.535 \\
\hline $\mathrm{N}$ & 14517 & 211756 & 14359 & 210999 & 14359 & 211006 & 14517 & 211756 & 14218 & 199976 \\
\hline
\end{tabular}


Table 4F: Impact of severe market liquidity shortages $\left(90^{\text {th }}\right.$ percentile) in normal time according to gap between actual and target capital

This table displays the impact of market liquidity shortages during normal time, on the change in total capital ratio $(\triangle T C R)$, on the change in asset part of risk weighted assets ( $\triangle \mathrm{RWA}$ ), on the change in asset part of total loans ( $\triangle \mathrm{LOAN}$ ), on the change in total assets ( $\triangle \mathrm{ASSET}$ ) and on dividend to total assets ratio (DIVIDEND) according to whether or not the bank is operating below its target total capital ratio. MLS $\mathrm{t}_{\mathrm{t}-1}$ is a dummy

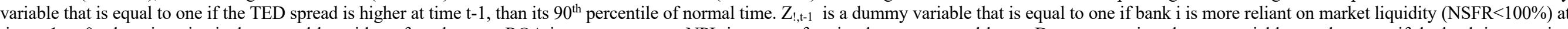

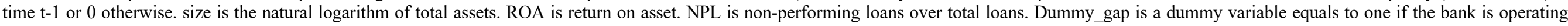

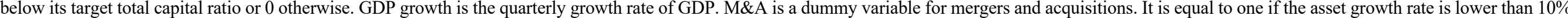

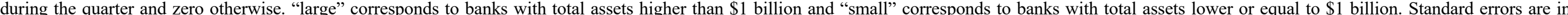
parentheses. *indicate statistical significance at the $10 \%$ level. $* *$ indicate statistical significance at the $5 \%$ level. $* * *$ indicate statistical significance at the $1 \%$ level.

\begin{tabular}{|c|c|c|c|c|c|c|c|c|c|c|}
\hline & \multicolumn{2}{|c|}{$\Delta \mathrm{TCR}$} & \multicolumn{2}{|c|}{$\Delta$ RWA } & \multicolumn{2}{|c|}{$\triangle \mathrm{LOANS}$} & \multicolumn{2}{|c|}{$\triangle \mathrm{ASSET}$} & \multicolumn{2}{|c|}{ DIVIDEND } \\
\hline & LARGE & SMALL & LARGE & SMALL & LARGE & SMALL & LARGE & SMALL & LARGE & SMALL \\
\hline \multirow[t]{2}{*}{$M L S_{t-1}\left(\omega_{1}\right)$} & -0.588 & $0.213^{* *}$ & $1.360^{*}$ & $-0.270^{*}$ & -0.516 & $-0.363^{* *}$ & 0.524 & $-0.381^{* *}$ & $0.119^{*}$ & $0.0499^{*}$ \\
\hline & $(0.607)$ & $(0.0962)$ & $(0.752)$ & $(0.156)$ & $(0.827)$ & $(0.150)$ & $(0.702)$ & $(0.171)$ & $(0.0646)$ & $(0.0262)$ \\
\hline \multirow{2}{*}{$Z_{i, t-1}\left(\omega_{2}\right)$} & 0.0898 & $0.0928^{* * *}$ & -0.162 & $-0.192^{* * *}$ & $-0.561^{* *}$ & $-0.311^{* * *}$ & 0.0685 & 0.0422 & -0.00960 & 0.00170 \\
\hline & $(0.176)$ & $(0.0140)$ & $(0.222)$ & $(0.0245)$ & $(0.264)$ & $(0.0244)$ & $(0.204)$ & $(0.0259)$ & $(0.0186)$ & $(0.00467)$ \\
\hline$d u m m y \_g a p_{i, t-1}\left(\omega_{3}\right)$ & $0.594^{* * *}$ & $0.417^{* * *}$ & $-0.866^{* * *}$ & $-0.958^{* * *}$ & $-0.421^{* *}$ & $-0.513^{* * *}$ & $0.462^{* * *}$ & $0.202^{* * *}$ & $-0.0490^{* * *}$ & $-0.0164^{* * *}$ \\
\hline \multirow[t]{2}{*}{$d u m m y \_g a p_{i, t-1} * M L S_{t-1}\left(\omega_{4}\right)$} & 0.394 & $0.334^{* * *}$ & -0.678 & $-0.560^{* * *}$ & 0.0608 & $-0.167^{* * *}$ & -0.466 & -0.0279 & -0.0656 & -0.000446 \\
\hline & $(0.433)$ & $(0.0337)$ & $(0.615)$ & $(0.0726)$ & $(0.680)$ & $(0.0528)$ & $(0.431)$ & $(0.0629)$ & $(0.0525)$ & $(0.0127)$ \\
\hline \multirow[t]{2}{*}{ Size $_{i, t-1}$} & 0.202 & $0.969^{* * *}$ & 0.152 & $-0.721^{* * *}$ & -0.612 & $-1.098^{* * *}$ & $-2.248^{* * *}$ & $-2.269^{* * *}$ & 0.0230 & $-0.0902^{* * *}$ \\
\hline & $(0.294)$ & $(0.0584)$ & $(0.401)$ & $(0.0682)$ & $(0.373)$ & $(0.0767)$ & $(0.271)$ & $(0.0883)$ & $(0.0171)$ & $(0.0129)$ \\
\hline \multirow[t]{2}{*}{$\mathrm{ROA}_{i, t-1}$} & $0.255^{* * *}$ & $0.387^{* * *}$ & -0.0481 & $-0.198^{* * *}$ & $-0.159^{* *}$ & $-0.323^{* * *}$ & $0.319^{* * *}$ & $0.197^{* * *}$ & $0.0120^{* *}$ & $0.00496^{* *}$ \\
\hline & $(0.0527)$ & $(0.0139)$ & $(0.0658)$ & $(0.0195)$ & $(0.0786)$ & $(0.0205)$ & $(0.0651)$ & $(0.0159)$ & $(0.00603)$ & $(0.00220)$ \\
\hline $\mathrm{NPL}_{i, t-1}$ & $0.0653^{* *}$ & $0.0938^{* * *}$ & $-0.0933^{* * *}$ & $-0.130^{* * *}$ & $-0.149^{* * *}$ & $-0.177^{* * *}$ & $-0.253^{* * *}$ & $-0.302^{* * *}$ & -0.00340 & 0.000875 \\
\hline \multirow[t]{2}{*}{ GDP growth $_{t-1}$} & 0.262 & $0.137^{* *}$ & 0.0359 & $0.460^{* * *}$ & 0.0909 & $0.508^{* * *}$ & $-1.178^{* * *}$ & $-0.812^{* * *}$ & $-0.0394^{* *}$ & $-0.0990^{* * *}$ \\
\hline & $(0.306)$ & $(0.0545)$ & $(0.297)$ & $(0.0935)$ & $(0.373)$ & $(0.0917)$ & $(0.271)$ & $(0.0993)$ & $(0.0194)$ & $(0.0112)$ \\
\hline \multirow[t]{2}{*}{$M \& A_{i, t-1}$} & $0.994^{* * *}$ & $1.309^{* * *}$ & $2.705^{* * *}$ & $3.224^{* * *}$ & $1.959^{* * *}$ & $3.615^{* * *}$ & $-15.23^{* * *}$ & $-13.02^{* * *}$ & 0.0161 & $0.0182^{* * *}$ \\
\hline & $(0.127)$ & $(0.0418)$ & $(0.231)$ & $(0.0713)$ & $(0.269)$ & $(0.0813)$ & $(0.291)$ & $(0.0856)$ & $(0.0172)$ & $(0.00674)$ \\
\hline Banks fixed effect & yes & yes & yes & yes & yes & yes & yes & yes & yes & yes \\
\hline time fixed effect & yes & yes & yes & yes & yes & yes & yes & yes & yes & yes \\
\hline$\omega_{1}+\omega_{4}$ & -0.194 & 0.548 & 0.682 & -0.829 & -0.456 & -0.530 & 0.0583 & -0.409 & 0.0531 & 0.0494 \\
\hline Wald test $p$ value & 0.751 & 0.000 & 0.379 & 0.000 & 0.561 & 0.001 & 0.926 & 0.024 & 0.166 & 0.0610 \\
\hline $\mathrm{r} 2$ & 0.0841 & 0.201 & 0.109 & 0.0942 & 0.0726 & 0.137 & 0.630 & 0.537 & 0.433 & 0.535 \\
\hline $\mathrm{N}$ & 14517 & 211756 & 14359 & 210999 & 14359 & 211006 & 14517 & 211756 & 14218 & 199976 \\
\hline
\end{tabular}


Table 5F: Impact of severe market liquidity shortages (mean plus two times standard deviation) in normal time according to bank liquidity level

This table displays the impact of market liquidity shortages during normal time on the change in total capital ratio ( $\triangle \mathrm{TCR}$ ), on the change in asset part of risk weighted assets ( $\triangle \mathrm{RWA}$ ), on the change in asset part of total loans $\left(\triangle \mathrm{LOAN}\right.$ ), on the change in total assets ( $\triangle \mathrm{ASSET}$ ) and on dividend to total assets ratio (DIVIDEND) according to whether or not the bank is more reliant on market liquidity. MLS $\mathrm{S}_{\mathrm{t}-1}$ is a dummy variable that is equal to one if the TED spread is higher at time $t-1$, than its mean plus two times its standard deviation of normal time. $Z_{t, t-1}$ is a dummy variable that is equal to one if bank $i$ is more reliant on market liquidity (NSFR $<100 \%$ ) at time t-1 or 0 otherwise. size is the natural logarithm of total assets. ROA is return on asset. NPL is non-performing loans over total loans. Dummy_gap is a dummy variable equals to one if the bank is operating below its target total capital ratio or 0 otherwise. GDP growth is the quarterly growth rate of GDP. M\&A is a dummy variable for mergers and acquisitions. It is equal to one if the asset growth rate is lower than $10 \%$ during the quarter and zero otherwise. "large" corresponds to banks with total assets higher than $\$ 1$ billion and "small" corresponds to banks with total assets lower or equal to $\$ 1$ billion. Standard errors are in parentheses. *indicate statistical significance at the $10 \%$ level. $* *$ indicate statistical significance at the $5 \%$ level. $* *$ indicate statistical significance at the $1 \%$ level.

\begin{tabular}{|c|c|c|c|c|c|c|c|c|c|c|}
\hline & \multicolumn{2}{|c|}{$\triangle \mathrm{TCR}$} & \multicolumn{2}{|c|}{$\Delta \mathrm{RWA}$} & \multicolumn{2}{|c|}{$\triangle \mathrm{LOANS}$} & \multicolumn{2}{|c|}{$\triangle \mathrm{ASSET}$} & \multicolumn{2}{|c|}{ DIVIDEND } \\
\hline & LARGE & SMALL & LARGE & SMALL & LARGE & SMALL & LARGE & SMALL & LARGE & SMALL \\
\hline \multirow[t]{2}{*}{$M L S_{t-1}\left(\varphi_{1}\right)$} & 0.436 & $0.804^{* * *}$ & $1.907^{* *}$ & $-0.594^{* * *}$ & -0.0576 & $-1.202^{* * *}$ & $-3.669^{* * *}$ & $-2.092^{* * *}$ & 0.0526 & $-0.120^{* * *}$ \\
\hline & $(0.505)$ & $(0.0803)$ & $(0.904)$ & $(0.145)$ & $(0.884)$ & $(0.109)$ & $(0.939)$ & $(0.119)$ & $(0.0971)$ & $(0.0194)$ \\
\hline \multirow[t]{2}{*}{$Z_{i, t-1}\left(\varphi_{2}\right)$} & 0.0896 & $0.0842^{* * *}$ & -0.0827 & $-0.190^{* * *}$ & $-0.500^{*}$ & $-0.314^{* * *}$ & 0.0648 & 0.0407 & -0.00802 & 0.00287 \\
\hline & $(0.178)$ & $(0.0142)$ & $(0.228)$ & $(0.0248)$ & $(0.271)$ & $(0.0250)$ & $(0.204)$ & $(0.0265)$ & $(0.0181)$ & $(0.00473)$ \\
\hline$d u m m y_{-} g a p_{i, t-1}\left(\varphi_{3}\right)$ & $0.624^{* * *}$ & $0.448^{* * *}$ & $-0.920^{* * *}$ & $-1.009^{* * *}$ & $-0.417^{* *}$ & $-0.529^{* * *}$ & $0.426^{* * *}$ & $0.200^{* * *}$ & $-0.0536^{* * *}$ & $-0.0164^{* * *}$ \\
\hline \multirow[t]{2}{*}{$Z_{i, t-1} * M L S_{t-1}\left(\varphi_{4}\right)$} & 0.00494 & $0.105^{* *}$ & $-1.578^{* *}$ & -0.0231 & $-1.215^{*}$ & 0.0383 & 0.0747 & 0.0177 & -0.0404 & $-0.0228^{*}$ \\
\hline & $(0.191)$ & $(0.0427)$ & $(0.756)$ & $(0.0845)$ & $(0.735)$ & $(0.0586)$ & $(0.806)$ & $(0.0641)$ & $(0.0876)$ & $(0.0133)$ \\
\hline \multirow[t]{2}{*}{$\operatorname{Size}_{i, t-1}$} & 0.197 & $0.957^{* * *}$ & 0.152 & $-0.701^{* * *}$ & $-0.620^{*}$ & $-1.092^{* * *}$ & $-2.242^{* * *}$ & $-2.268^{* * *}$ & 0.0234 & $-0.0903^{* * *}$ \\
\hline & $(0.293)$ & $(0.0579)$ & (0.399) & $(0.0678)$ & $(0.370)$ & $(0.0763)$ & $(0.271)$ & $(0.0879)$ & $(0.0171)$ & $(0.0128)$ \\
\hline \multirow[t]{2}{*}{$\mathrm{ROA}_{i, t-1}$} & $0.255^{* * *}$ & $0.387^{* * *}$ & -0.0491 & $-0.198^{* * *}$ & $-0.160^{* *}$ & $-0.323^{* * *}$ & $0.319^{* * *}$ & $0.197^{* * *}$ & $0.0120^{* *}$ & $0.00496^{* *}$ \\
\hline & $(0.0527)$ & $(0.0139)$ & $(0.0660)$ & $(0.0195)$ & $(0.0786)$ & $(0.0205)$ & $(0.0652)$ & $(0.0159)$ & $(0.00600)$ & $(0.00220)$ \\
\hline \multirow[t]{2}{*}{$\mathrm{NPL}_{i, t-1}$} & $0.0649^{* *}$ & $0.0932^{* * *}$ & $-0.0936^{* * *}$ & $-0.129^{* * *}$ & $-0.150^{* * *}$ & $-0.177^{* * *}$ & $-0.252^{* * *}$ & $-0.302^{* * *}$ & -0.00341 & 0.000827 \\
\hline & $(0.0269)$ & $(0.00437)$ & $(0.0299)$ & $(0.00672)$ & $(0.0398)$ & $(0.00727)$ & $(0.0452)$ & $(0.00804)$ & $(0.00700)$ & $(0.00111)$ \\
\hline \multirow[t]{2}{*}{ GDP growth $_{t-1}$} & 0.112 & $0.277^{* * *}$ & $0.473^{*}$ & $0.271^{* * *}$ & -0.155 & $0.305^{* * *}$ & $-1.088^{* * *}$ & $-1.012^{* * *}$ & -0.00323 & $-0.0732^{* * *}$ \\
\hline & $(0.216)$ & $(0.0335)$ & $(0.282)$ & $(0.0507)$ & $(0.270)$ & $(0.0511)$ & $(0.233)$ & $(0.0543)$ & $(0.0216)$ & (0.0109) \\
\hline \multirow[t]{2}{*}{$M \& A_{i, t-1}$} & $0.993^{* * *}$ & $1.311^{* * *}$ & $2.714^{* * *}$ & $3.220^{* * *}$ & $1.964^{* * *}$ & $3.614^{* * *}$ & $-15.22^{* * *}$ & $-13.02^{* * *}$ & 0.0166 & $0.0182^{* * *}$ \\
\hline & $(0.127)$ & $(0.0418)$ & $(0.230)$ & $(0.0713)$ & $(0.269)$ & $(0.0813)$ & $(0.291)$ & $(0.0856)$ & $(0.0172)$ & $(0.00673)$ \\
\hline Banks fixed effect & yes & yes & yes & yes & yes & yes & yes & yes & yes & yes \\
\hline time fixed effect & yes & yes & yes & yes & yes & yes & yes & yes & yes & yes \\
\hline$\varphi_{1}+\varphi_{4}$ & 0.441 & 0.909 & 0.329 & -0.617 & -1.273 & -1.163 & -3.595 & -2.074 & 0.0122 & -0.143 \\
\hline Wald test $\mathrm{p}$ value & 0.300 & 0.000 & 0.559 & 0.000 & 0.0263 & 0.000 & 0.000 & 0.000 & 0.770 & 0.000 \\
\hline $\mathrm{r} 2$ & 0.0838 & 0.200 & 0.110 & 0.0939 & 0.0730 & 0.137 & 0.630 & 0.537 & 0.433 & 0.535 \\
\hline $\mathrm{N}$ & 14517 & 211756 & 14359 & 210999 & 14359 & 211006 & 14517 & 211756 & 14218 & 199976 \\
\hline
\end{tabular}


Table 6F: Impact of market liquidity shortages (mean plus two times standard deviation) in normal time according to gap between actual and target capital

This table displays the impact of market liquidity shortages during normal time, on the change in total capital ratio ( $\triangle \mathrm{TCR}$ ), on the change in asset part of risk weighted assets ( $\triangle \mathrm{RWA}$ ), on the change in asset part of total loans $(\triangle \mathrm{LOAN})$, on the change in total assets ( $\triangle \mathrm{ASSET}$ ) and on dividend to total assets ratio (DIVIDEND) according to whether or not the bank is operating below its target total capital ratio. MLS $\mathrm{T}_{\mathrm{t}-1}$ is a dummy variable that is equal to one if the TED spread is higher at time $t-1$, than its mean plus two times its standard deviation of normal time. $Z_{t, t-1}$ is a dummy variable that is equal to one if bank $i$ is more reliant on market liquidity (NSFR $<100 \%$ ) at time t-1 or 0 otherwise. size is the natural logarithm of total assets. ROA is return on asset. NPL is non-performing loans over total loans. Dummy_gap is a dummy variable equals to one if the bank is operating below its target total capital ratio or 0 otherwise. GDP growth is the quarterly growth rate of GDP. M\&A is a dummy variable for mergers and acquisitions. It is equal to one if the asset growth rate is lower than $10 \%$ during the quarter and zero otherwise "large" corresponds to banks with total assets higher than $\$ 1$ billion and "small" corresponds to banks with total assets lower or equal to $\$ 1$ billion Standard erors are in parenthese * *

\begin{tabular}{|c|c|c|c|c|c|c|c|c|c|c|}
\hline & \multicolumn{2}{|c|}{$\Delta \mathrm{TCR}$} & \multicolumn{2}{|c|}{$\Delta \mathrm{RWA}$} & \multicolumn{2}{|c|}{$\triangle$ LOANS } & \multicolumn{2}{|c|}{$\triangle \mathrm{ASSET}$} & \multicolumn{2}{|c|}{ DIVIDEND } \\
\hline & LARGE & SMALL & LARGE & SMALL & LARGE & SMALL & LARGE & SMALL & LARGE & SMALL \\
\hline \multirow[t]{2}{*}{$M L S_{t-1}\left(\omega_{1}\right)$} & 0.158 & $0.776^{* * *}$ & 0.743 & $-0.456^{* * *}$ & $-1.673^{*}$ & $-1.168^{* * *}$ & $-3.087^{* * *}$ & $-2.022^{* * *}$ & 0.0346 & $-0.134^{* * *}$ \\
\hline & $(0.518)$ & $(0.0759)$ & $(0.609)$ & $(0.139)$ & $(0.879)$ & $(0.105)$ & $(0.707)$ & $(0.115)$ & (0.0669) & $(0.0180)$ \\
\hline \multirow[t]{2}{*}{$Z_{i, t-1}\left(\omega_{2}\right)$} & 0.0909 & $0.0928^{* * *}$ & -0.163 & $-0.192^{* * *}$ & $-0.559^{* *}$ & $-0.311^{* * *}$ & 0.0665 & 0.0425 & -0.00975 & 0.00170 \\
\hline & $(0.175)$ & $(0.0140)$ & $(0.222)$ & $(0.0245)$ & $(0.264)$ & $(0.0244)$ & $(0.204)$ & $(0.0259)$ & $(0.0187)$ & $(0.00467)$ \\
\hline \multirow[t]{2}{*}{$d u m m y_{-} g a p_{i, t-1}\left(\omega_{3}\right)$} & $0.607^{* * *}$ & $0.428^{* * *}$ & $-0.905^{* * *}$ & $-0.973^{* * *}$ & $-0.450^{* *}$ & $-0.526^{* * *}$ & $0.458^{* * *}$ & $0.214^{* * *}$ & $-0.0526^{* * *}$ & $-0.0167^{* * *}$ \\
\hline & $(0.111)$ & $(0.0174)$ & $(0.155)$ & $(0.0337)$ & $(0.181)$ & $(0.0300)$ & $(0.149)$ & $(0.0315)$ & $(0.0163)$ & $(0.00504)$ \\
\hline \multirow[t]{2}{*}{$d u m m y_{-} g a p_{i, t-1} * M L S_{t-1}\left(\omega_{4}\right)$} & 0.348 & $0.280^{* * * *}$ & -0.282 & $-0.501^{* * *}$ & 0.671 & -0.0439 & -0.637 & $-0.199^{* * *}$ & -0.0216 & 0.00533 \\
\hline & $(0.553)$ & $(0.0351)$ & $(0.732)$ & $(0.0812)$ & $(0.888)$ & $(0.0572)$ & $(0.540)$ & $(0.0659)$ & $(0.0527)$ & $(0.0128)$ \\
\hline \multirow[t]{2}{*}{$\operatorname{Size}_{i, t-1}$} & 0.200 & $0.965^{* * *}$ & 0.158 & $-0.715^{* * *}$ & -0.607 & $-1.093^{* * *}$ & $-2.248^{* * *}$ & $-2.274^{* * *}$ & 0.0235 & $-0.0901^{* * *}$ \\
\hline & $(0.294)$ & $(0.0582)$ & $(0.402)$ & $(0.0680)$ & $(0.374)$ & $(0.0765)$ & $(0.271)$ & $(0.0883)$ & $(0.0171)$ & $(0.0129)$ \\
\hline \multirow[t]{2}{*}{$\mathrm{ROA}_{i, t-1}$} & $0.256^{* * *}$ & $0.387^{* * *}$ & -0.0481 & $-0.198^{* * *}$ & $-0.158^{* *}$ & $-0.323^{* * *}$ & $0.318^{* * *}$ & $0.197^{* * *}$ & $0.0120^{* *}$ & $0.00496^{* *}$ \\
\hline & $(0.0527)$ & $(0.0139)$ & $(0.0660)$ & $(0.0195)$ & $(0.0784)$ & $(0.0205)$ & $(0.0651)$ & $(0.0159)$ & $(0.00604)$ & $(0.00220)$ \\
\hline \multirow[t]{2}{*}{$\mathrm{NPL}_{i, t-1}$} & $0.0652^{* *}$ & $0.0935^{* * *}$ & $-0.0928^{* * *}$ & $-0.130^{* * *}$ & $-0.148^{* * *}$ & $-0.177^{* * *}$ & $-0.253^{* * *}$ & $-0.302^{* * *}$ & -0.00339 & 0.000882 \\
\hline & $(0.0269)$ & $(0.00437)$ & $(0.0300)$ & $(0.00672)$ & $(0.0397)$ & $(0.00726)$ & $(0.0452)$ & $(0.00804)$ & $(0.00701)$ & $(0.00111)$ \\
\hline \multirow[t]{2}{*}{ GDP growth $_{t-1}$} & 0.115 & $0.281^{* * *}$ & $0.473^{*}$ & $0.264^{* * *}$ & -0.146 & $0.305^{* * *}$ & $-1.095^{* * * *}$ & $-1.015^{* * *}$ & -0.00334 & $-0.0731^{* * *}$ \\
\hline & $(0.217)$ & $(0.0336)$ & $(0.286)$ & $(0.0508)$ & $(0.274)$ & $(0.0512)$ & $(0.233)$ & $(0.0544)$ & $(0.0215)$ & $(0.0109)$ \\
\hline \multirow[t]{2}{*}{$M \& A_{i, t-1}$} & $0.994^{* * *}$ & $1.310^{* * *}$ & $2.706^{* * *}$ & $3.224^{* * *}$ & $1.961^{* * *}$ & $3.615^{* * *}$ & $-15.23^{* * *}$ & $-13.02^{* * *}$ & 0.0164 & $0.0182^{* * *}$ \\
\hline & $(0.127)$ & $(0.0418)$ & $(0.231)$ & $(0.0713)$ & $(0.270)$ & $(0.0813)$ & $(0.291)$ & $(0.0857)$ & $(0.0173)$ & $(0.00674)$ \\
\hline Banks fixed effect & yes & yes & yes & yes & yes & yes & yes & yes & yes & yes \\
\hline time fixed effect & yes & yes & yes & yes & yes & yes & yes & yes & yes & yes \\
\hline$\omega_{1}+\omega_{4}$ & 0.506 & 1.057 & 0.461 & -0.957 & -1.002 & -1.212 & -3.724 & -2.221 & 0.0130 & -0.128 \\
\hline Wald test $\mathrm{p}$ value & 0.284 & 0.000 & 0.470 & 0.000 & 0.100 & 0.000 & 0.000 & 0.000 & 0.758 & 0.000 \\
\hline $\mathrm{r} 2$ & 0.0840 & 0.200 & 0.109 & 0.0941 & 0.0728 & 0.137 & 0.630 & 0.537 & 0.432 & 0.535 \\
\hline $\mathrm{N}$ & 14517 & 211756 & 14359 & 210999 & 14359 & 211006 & 14517 & 211756 & 14218 & 199976 \\
\hline
\end{tabular}




\section{APPENDIX G:}

\section{TABLE 1G: Impact of market liquidity shortages on the change in large banks' total capital}

ratio $(\triangle \mathrm{TCR})$ according to their liquidity level

This table displays the impact of market liquidity shortages on the change in total capital ratio ( $\Delta \mathrm{TCR})$ of large banks according to whether or not they are more reliant on market liquidity and the level of risk management. We compare each bank's futures contracts committing to purchase or sell equity securities and each bank's swap notional value to the respective medians of both variables (both medians equal 0 ). We consider that banks have a better risk management if their amount of futures contracts committing them to purchase or sell equity securities is higher than the median and banks have a poor risk management if their amount of futures contracts committing them to purchase or sell equity securities is equal to the median; or banks are also said to have a better risk management if their swap notional value is higher than the median and banks have a poor risk management if their swap national value is equal to the median. MLS $_{\mathrm{t}-1}$ is a dummy variable that is equal to one if the TED spread is higher than its $75^{\text {th }}$ percentile at time $t-1$. $Z_{!, t-1}$ is a dummy variable that is equal to one if bank $i$ is more reliant on market liquidity at time t- 1 or 0 otherwise. size is the natural logarithm of total assets. ROA is return on asset. NPL is non-performing loans over total loans. Dummy_gap is a dummy variable equals to one if the bank is operating below its target total capital ratio or 0 otherwise. GDP growth is the quarterly growth rate of GDP. M\&A is a dummy variable for mergers and acquisitions. It is equal to one if the asset growth rate is lower than $10 \%$ during the quarter and zero otherwise. large banks are banks with total assets higher than $\$ 1$ billion. Standard errors are in parentheses. *indicate statistical significance at the $10 \%$ level. **indicate statistical significance at the $5 \%$ level. $* * *$ indicate statistical significance at the $1 \%$ level.

\begin{tabular}{|c|c|c|c|c|}
\hline & \multicolumn{2}{|c|}{$\begin{array}{l}\text { Futures contracts committing to } \\
\text { purchase or sell equity securities }\end{array}$} & \multicolumn{2}{|c|}{ swap national value } \\
\hline & $\begin{array}{c}\text { Better risk } \\
\text { management }\end{array}$ & $\begin{array}{c}\text { poor risk } \\
\text { management }\end{array}$ & $\begin{array}{c}\text { Better risk } \\
\text { management }\end{array}$ & $\begin{array}{c}\text { poor risk } \\
\text { management }\end{array}$ \\
\hline$M L S_{t-1}\left(\varphi_{1}\right)$ & $\begin{array}{c}2.540 \\
(1.866)\end{array}$ & $\begin{array}{l}-0.605 \\
(0.589)\end{array}$ & $\begin{array}{c}-1.895 \\
(1.457)\end{array}$ & $\begin{array}{c}-0.00229 \\
(0.589)\end{array}$ \\
\hline$Z_{i, t-1}\left(\varphi_{2}\right)$ & $\begin{array}{l}2.078 \\
(1.320)\end{array}$ & $\begin{array}{l}0.0788 \\
(0.169)\end{array}$ & $\begin{array}{c}0.503 \\
(0.397)\end{array}$ & $\begin{array}{l}0.0271 \\
(0.171)\end{array}$ \\
\hline$d u m m y \_g a p_{i, t-1}\left(\varphi_{3}\right)$ & $\begin{array}{l}2.387^{* *} \\
(0.967)\end{array}$ & $\begin{array}{l}0.575^{* * *} \\
(0.0963)\end{array}$ & $\begin{array}{l}0.720^{* * *} \\
(0.235)\end{array}$ & $\begin{array}{l}0.600^{* * * *} \\
(0.107)\end{array}$ \\
\hline$Z_{i, t-1} * M L S_{t-1}\left(\varphi_{4}\right)$ & $\begin{array}{l}0 \\
(.)\end{array}$ & $\begin{array}{c}0.168 \\
(0.148)\end{array}$ & $\begin{array}{c}0.273 \\
(0.479)\end{array}$ & $\begin{array}{l}0.128 \\
(0.153)\end{array}$ \\
\hline Size $_{i, t-1}$ & $\begin{array}{c}2.064 \\
(1.240)\end{array}$ & $\begin{array}{l}0.0991 \\
(0.280)\end{array}$ & $\begin{array}{l}0.0359 \\
(0.237)\end{array}$ & $\begin{array}{l}0.210 \\
(0.407)\end{array}$ \\
\hline $\mathrm{ROA}_{i, t-1}$ & $\begin{array}{c}0.286 \\
(0.245)\end{array}$ & $\begin{array}{l}0.224^{* * *} \\
(0.0367)\end{array}$ & $\begin{array}{l}0.317^{* * *} \\
(0.0728)\end{array}$ & $\begin{array}{l}0.207^{* * *} \\
(0.0426)\end{array}$ \\
\hline $\mathrm{NPL}_{i, t-1}$ & $\begin{array}{l}0.0839 \\
(0.103)\end{array}$ & $\begin{array}{l}0.0554^{* *} \\
(0.0218)\end{array}$ & $\begin{array}{l}0.0741^{* *} \\
(0.0319)\end{array}$ & $\begin{array}{l}0.0486^{*} \\
(0.0259)\end{array}$ \\
\hline GDP growth $_{t-1}$ & $\begin{array}{l}-0.0406 \\
(0.235)\end{array}$ & $\begin{array}{c}0.284 \\
(0.315)\end{array}$ & $\begin{array}{l}1.109 \\
(1.071)\end{array}$ & $\begin{array}{l}-0.0380 \\
(0.137)\end{array}$ \\
\hline$M \& A_{i, t-1}$ & $\begin{array}{c}0.421 \\
(0.307)\end{array}$ & $\begin{array}{l}0.903^{* * *} \\
(0.114)\end{array}$ & $\begin{array}{c}0.864^{* * * *} \\
(0.175)\end{array}$ & $\begin{array}{l}0.889^{* * *} \\
(0.131)\end{array}$ \\
\hline $\begin{array}{l}\text { Banks fixed effect } \\
\text { time fixed effect }\end{array}$ & $\begin{array}{l}\text { yes } \\
\text { yes }\end{array}$ & $\begin{array}{l}\text { yes } \\
\text { yes }\end{array}$ & $\begin{array}{l}\text { yes } \\
\text { yes }\end{array}$ & $\begin{array}{l}\text { yes } \\
\text { yes }\end{array}$ \\
\hline $\begin{array}{l}\varphi_{1}+\varphi_{4} \\
\text { Wald test } \mathrm{p} \text { value }\end{array}$ & $\begin{array}{l}2.540 \\
0.222 \\
0.387\end{array}$ & $\begin{array}{c}-0.436 \\
0.450\end{array}$ & $\begin{array}{c}-1.622 \\
0.316\end{array}$ & $\begin{array}{r}0.126 \\
0.806\end{array}$ \\
\hline $\begin{array}{l}\mathrm{r} 2 \\
\mathrm{~N}\end{array}$ & $\begin{array}{c}0.387 \\
205\end{array}$ & $\begin{array}{l}0.0758 \\
17077\end{array}$ & $\begin{array}{l}0.104 \\
3695\end{array}$ & $\begin{array}{l}0.0853 \\
13587\end{array}$ \\
\hline
\end{tabular}


TABLE 2G: Impact of market liquidity shortages on the change in large banks' total capital ratio $(\triangle T C R)$ according to gap between actual and target capital

This table displays the impact of market liquidity shortages on the change in total capital ratio ( $\Delta \mathrm{TCR})$ of large banks according to gap between actual and target capital and the level of risk management. We compare each bank's futures contracts committing to purchase or sell equity securities and each bank's swap notional value to the respective medians of both variables (both medians equal 0 ). We consider that banks have a better risk management if their amount of futures contracts committing them to purchase or sell equity securities is higher than the median and banks have a poor risk management if their amount of futures contracts committing them to purchase or sell equity securities is equal to the median; or banks are also said to have a better risk management if their swap notional value is higher than the median and banks have a poor risk management if their swap national value is equal to the median. MLS $_{\mathrm{t}-1}$ is a dummy variable that is equal to one if the TED spread is higher than its $75^{\text {th }}$ percentile at time $t-1 . Z_{!, t-1}$ is a dummy variable that is equal to one if bank $i$ is more reliant on market liquidity at time t1 or 0 otherwise. size is the natural logarithm of total assets. ROA is return on asset. NPL is non-performing loans over total loans. Dummy_gap is a dummy variable equals to one if the bank is operating below its target total capital ratio or 0 otherwise. GDP growth is the quarterly growth rate of GDP. M\&A is a dummy variable for mergers and acquisitions. It is equal to one if the asset growth rate is lower than $10 \%$ during the quarter and zero otherwise. large banks are banks with total assets higher than $\$ 1$ billion. Standard errors are in parentheses. *indicate statistical significance at the $10 \%$ level. **indicate statistical significance at the $5 \%$ level. ***indicate statistical significance at the $1 \%$ level.

\begin{tabular}{|c|c|c|c|c|}
\hline & \multicolumn{2}{|c|}{$\begin{array}{l}\text { Futures contracts committing to } \\
\text { purchase or sell equity securities }\end{array}$} & \multicolumn{2}{|c|}{ swap national value } \\
\hline & $\begin{array}{l}\text { Better risk } \\
\text { management }\end{array}$ & $\begin{array}{c}\text { poor risk } \\
\text { management }\end{array}$ & $\begin{array}{c}\text { Better risk } \\
\text { management }\end{array}$ & $\begin{array}{c}\text { poor risk } \\
\text { management }\end{array}$ \\
\hline$M L S_{t-1}\left(\omega_{1}\right)$ & $\begin{array}{l}8.503^{*} \\
(3.606)\end{array}$ & $\begin{array}{l}-0.669 \\
(0.580)\end{array}$ & $\begin{array}{l}-1.592 \\
(1.632)\end{array}$ & $\begin{array}{l}-0.120 \\
(0.512)\end{array}$ \\
\hline$Z_{i, t-1}\left(\omega_{2}\right)$ & $\begin{array}{c}1.690 \\
(1.071)\end{array}$ & $\begin{array}{c}0.112 \\
(0.160)\end{array}$ & $\begin{array}{c}0.544 \\
(0.380)\end{array}$ & $\begin{array}{l}0.0530 \\
(0.152)\end{array}$ \\
\hline$d u m m y \_g a p_{i, t-1}\left(\omega_{3}\right)$ & $\begin{array}{l}2.776^{* *} \\
(0.992)\end{array}$ & $\begin{array}{l}0.512^{* * * *} \\
(0.106)\end{array}$ & $\begin{array}{l}0.736^{* * *} \\
(0.271)\end{array}$ & $\begin{array}{l}0.526^{* * *} \\
(0.117)\end{array}$ \\
\hline $\begin{array}{l}\text { dummy_gap } p_{i, t-1} * M L S_{t-1} \\
\left(\omega_{4}\right)\end{array}$ & $\begin{array}{l}-5.142^{* *} \\
(1.587)\end{array}$ & $\begin{array}{l}0.280^{*} \\
(0.157)\end{array}$ & $\begin{array}{c}-0.0648 \\
(0.360)\end{array}$ & $\begin{array}{l}0.315^{*} \\
(0.174)\end{array}$ \\
\hline Size $_{i, t-1}$ & $\begin{array}{c}2.431 \\
(1.534)\end{array}$ & $\begin{array}{l}0.1000 \\
(0.281)\end{array}$ & $\begin{array}{l}0.0288 \\
(0.237)\end{array}$ & $\begin{array}{c}0.211 \\
(0.408)\end{array}$ \\
\hline $\mathrm{ROA}_{i, t-1}$ & $\begin{array}{c}0.178 \\
(0.165)\end{array}$ & $\begin{array}{l}0.223^{* * *} \\
(0.0365)\end{array}$ & $\begin{array}{l}0.317^{* * *} \\
(0.0725)\end{array}$ & $\begin{array}{l}0.207^{* * *} \\
(0.0423)\end{array}$ \\
\hline $\mathrm{NPL}_{i, t-1}$ & $\begin{array}{l}0.228 \\
(0.157)\end{array}$ & $\begin{array}{l}0.0547^{* *} \\
(0.0218)\end{array}$ & $\begin{array}{l}0.0743^{* *} \\
(0.0314)\end{array}$ & $\begin{array}{l}0.0480^{*} \\
(0.0258)\end{array}$ \\
\hline GDP growth $_{t-1}$ & $\begin{array}{l}-0.0716 \\
(0.310)\end{array}$ & $\begin{array}{c}0.284 \\
(0.315)\end{array}$ & $\begin{array}{l}1.108 \\
(1.071)\end{array}$ & $\begin{array}{l}-0.0371 \\
(0.137)\end{array}$ \\
\hline$M \& A_{i, t-1}$ & $\begin{array}{c}0.389 \\
(0.325)\end{array}$ & $\begin{array}{l}0.904^{* * *} \\
(0.114)\end{array}$ & $\begin{array}{l}0.868^{* * *} \\
(0.178)\end{array}$ & $\begin{array}{l}0.889^{* * *} \\
(0.131)\end{array}$ \\
\hline $\begin{array}{l}\text { Banks fixed effect } \\
\text { time fixed effect }\end{array}$ & $\begin{array}{l}\text { yes } \\
\text { yes }\end{array}$ & $\begin{array}{l}\text { yes } \\
\text { yes }\end{array}$ & $\begin{array}{l}\text { yes } \\
\text { yes }\end{array}$ & $\begin{array}{l}\text { yes } \\
\text { yes }\end{array}$ \\
\hline $\begin{array}{l}\varphi_{1}+\varphi_{4} \\
\text { Wald test } \mathrm{p} \text { value }\end{array}$ & $\begin{array}{l}3.361 \\
0.203\end{array}$ & $\begin{array}{l}-0.390 \\
0.503\end{array}$ & $\begin{array}{r}-1.657 \\
0.299\end{array}$ & $\begin{array}{l}0.195 \\
0.714\end{array}$ \\
\hline $\mathrm{r} 2$ & 0.408 & 0.0762 & 0.104 & 0.0859 \\
\hline $\mathrm{N}$ & 205 & 17077 & 3695 & 13587 \\
\hline
\end{tabular}


APPENDIX H:

TABLE 1H: Impact of market liquidity shortages on the change in banks' Tier one capital ratio (using alternative liquidity measures and different samples)

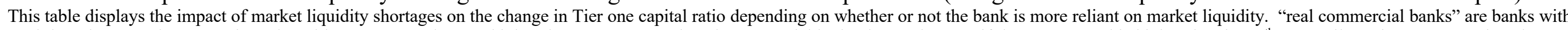

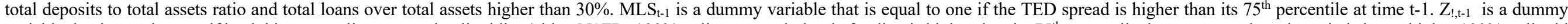

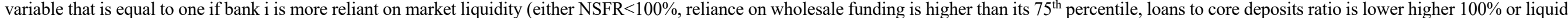

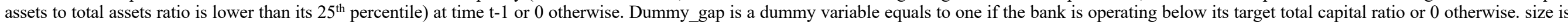

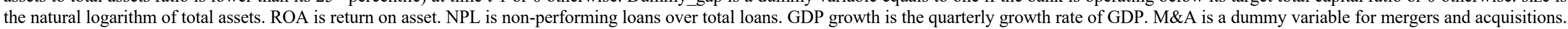

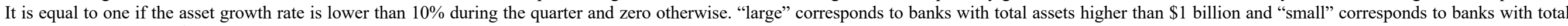

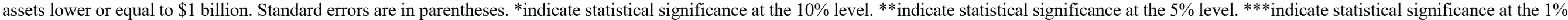
level.

\begin{tabular}{|c|c|c|c|c|c|c|c|c|c|c|}
\hline & \multicolumn{2}{|c|}{ NSFR ("real commercial bank") } & \multicolumn{2}{|c|}{$\begin{array}{l}\text { NSFR (whole } \\
\text { sample) }\end{array}$} & \multicolumn{2}{|c|}{$\begin{array}{c}\text { RESILANCE ON } \\
\text { WHOLESALE FUNDING }\end{array}$} & \multicolumn{2}{|c|}{$\begin{array}{l}\text { LOANS TO CORE } \\
\text { DEPOSIT RATIO }\end{array}$} & \multicolumn{2}{|c|}{$\begin{array}{c}\text { LIQUID ASSETS TO TOTAL } \\
\text { ASSETS RATIO }\end{array}$} \\
\hline & LARGE & SMALL & LARGE & SMALL & LARGE & SMALL & LARGE & SMALL & LARGE & SMALL \\
\hline$M L S_{t-1}\left(\varphi_{1}\right)$ & $\begin{array}{l}-0.241 \\
(0.434)\end{array}$ & $\begin{array}{l}0.301^{* * *} \\
(0.0918)\end{array}$ & $\begin{array}{l}-0.663 \\
(0.553)\end{array}$ & $\begin{array}{c}0.221^{* *} \\
(0.0960)\end{array}$ & $\begin{array}{l}-0.482 \\
(0.547)\end{array}$ & $\begin{array}{l}0.298^{* * *} \\
(0.0946)\end{array}$ & $\begin{array}{l}-0.726 \\
(0.514)\end{array}$ & $\begin{array}{l}0.266^{* * *} \\
(0.0934)\end{array}$ & $\begin{array}{l}-0.546 \\
(0.538)\end{array}$ & $\begin{array}{l}0.272^{* * *} \\
(0.0947)\end{array}$ \\
\hline$Z_{i, t-1}\left(\varphi_{2}\right)$ & $\begin{array}{l}0.0513 \\
(0.146)\end{array}$ & $\begin{array}{l}0.0740^{* * *} \\
(0.0132)\end{array}$ & $\begin{array}{l}0.0766 \\
(0.160)\end{array}$ & $\begin{array}{l}0.0772^{* * *} \\
(0.0134)\end{array}$ & $\begin{array}{l}-0.0269 \\
(0.0626)\end{array}$ & $\begin{array}{c}0.0239 \\
(0.0200)\end{array}$ & $\begin{array}{c}0.116 \\
(0.0839)\end{array}$ & $\begin{array}{l}0.204^{* * *} \\
(0.0225)\end{array}$ & $\begin{array}{c}0.0553 \\
(0.0399)\end{array}$ & $\begin{array}{l}0.0924^{* * *} \\
(0.0137)\end{array}$ \\
\hline$d u m m y_{-} g a p_{i, t-1}\left(\varphi_{3}\right)$ & $\begin{array}{l}0.579^{* * *} \\
(0.0889)\end{array}$ & $\begin{array}{l}0.377^{* * *} \\
(0.0147)\end{array}$ & $\begin{array}{l}0.548^{* * *} \\
(0.0922)\end{array}$ & $\begin{array}{l}0.399^{* * *} \\
(0.0151)\end{array}$ & $\begin{array}{l}0.542^{* * *} \\
(0.0921)\end{array}$ & $\begin{array}{l}0.399^{* * *} \\
(0.0152)\end{array}$ & $\begin{array}{l}0.504^{* * *} \\
(0.0907)\end{array}$ & $\begin{array}{l}0.389^{* * *} \\
(0.0150)\end{array}$ & $\begin{array}{l}0.540^{* * *} \\
(0.0929)\end{array}$ & $\begin{array}{l}0.384^{* * *} \\
(0.0151)\end{array}$ \\
\hline Size $_{i, t-1}$ & $\begin{array}{c}0.150 \\
(0.277)\end{array}$ & $\begin{array}{l}1.142^{* * *} \\
(0.0522)\end{array}$ & $\begin{array}{l}0.0612 \\
(0.263)\end{array}$ & $\begin{array}{l}1.011^{* * *} \\
(0.0534)\end{array}$ & $\begin{array}{l}0.0758 \\
(0.267)\end{array}$ & $\begin{array}{l}1.022^{* * *} \\
(0.0542)\end{array}$ & $\begin{array}{l}-0.0777 \\
(0.237)\end{array}$ & $\begin{array}{l}0.995^{* * *} \\
(0.0533)\end{array}$ & $\begin{array}{l}0.0634 \\
(0.264)\end{array}$ & $\begin{array}{l}1.013^{* * *} \\
(0.0535)\end{array}$ \\
\hline $\mathrm{ROA}_{i, t-1}$ & $\begin{array}{l}0.217^{* * *} \\
(0.0272)\end{array}$ & $\begin{array}{l}0.410^{* * *} \\
(0.0106)\end{array}$ & $\begin{array}{l}0.232^{* * *} \\
(0.0339)\end{array}$ & $\begin{array}{l}0.381^{* * *} \\
(0.0112)\end{array}$ & $\begin{array}{l}0.234^{* * *} \\
(0.0340)\end{array}$ & $\begin{array}{l}0.383^{* * *} \\
(0.0113)\end{array}$ & $\begin{array}{l}0.231^{* * *} \\
(0.0341)\end{array}$ & $\begin{array}{l}0.383^{* * *} \\
(0.0113)\end{array}$ & $\begin{array}{l}0.234^{* * *} \\
(0.0336)\end{array}$ & $\begin{array}{l}0.382^{* * *} \\
(0.0112)\end{array}$ \\
\hline $\mathrm{NPL}_{i, t-1}$ & $\begin{array}{l}0.0577^{* * * *} \\
(0.0185)\end{array}$ & $\begin{array}{l}0.0988^{* * *} \\
(0.00372)\end{array}$ & $\begin{array}{l}0.0559^{* * *} \\
(0.0199)\end{array}$ & $\begin{array}{l}0.0905^{* * *} \\
(0.00375)\end{array}$ & $\begin{array}{l}0.0564^{* * *} \\
(0.0202)\end{array}$ & $\begin{array}{l}0.0962^{* * *} \\
(0.00369)\end{array}$ & $\begin{array}{l}0.0562^{* * *} \\
(0.0208)\end{array}$ & $\begin{array}{l}0.0982^{* * *} \\
(0.00371)\end{array}$ & $\begin{array}{l}0.0584^{* * *} \\
(0.0202)\end{array}$ & $\begin{array}{l}0.0967^{* * *} \\
(0.00368)\end{array}$ \\
\hline GDP growth $_{t-1}$ & $\begin{array}{l}0.203 \\
(0.147)\end{array}$ & $\begin{array}{l}0.170^{* * *} \\
(0.0508)\end{array}$ & $\begin{array}{c}0.280 \\
(0.292)\end{array}$ & $\begin{array}{c}0.135^{* *} \\
(0.0540)\end{array}$ & $\begin{array}{c}0.281 \\
(0.292)\end{array}$ & $\begin{array}{c}0.135^{* *} \\
(0.0539)\end{array}$ & $\begin{array}{c}0.283 \\
(0.294)\end{array}$ & $\begin{array}{c}0.135^{* *} \\
(0.0540)\end{array}$ & $\begin{array}{c}0.281 \\
(0.292)\end{array}$ & $\begin{array}{c}0.138^{* *} \\
(0.0539)\end{array}$ \\
\hline $\begin{array}{l}\text { Banks fixed effect } \\
\text { time fixed effect }\end{array}$ & $\begin{array}{l}\text { yes } \\
\text { yes }\end{array}$ & $\begin{array}{l}\text { yes } \\
\text { yes }\end{array}$ & $\begin{array}{l}\text { yes } \\
\text { yes }\end{array}$ & $\begin{array}{l}\text { yes } \\
\text { yes }\end{array}$ & $\begin{array}{l}\text { yes } \\
\text { yes }\end{array}$ & $\begin{array}{l}\text { yes } \\
\text { yes }\end{array}$ & $\begin{array}{l}\text { yes } \\
\text { yes }\end{array}$ & $\begin{array}{l}\text { yes } \\
\text { yes }\end{array}$ & $\begin{array}{l}\text { yes } \\
\text { yes }\end{array}$ & $\begin{array}{l}\text { yes } \\
\text { yes }\end{array}$ \\
\hline $\begin{array}{l}\varphi_{1}+\varphi_{4} \\
\text { Wald test } \mathrm{p} \text { value }\end{array}$ & $\begin{array}{c}-0.158 \\
0.669\end{array}$ & $\begin{array}{l}0.464 \\
0.000\end{array}$ & $\begin{array}{c}-0.479 \\
0.373\end{array}$ & $\begin{array}{l}0.385 \\
0.000\end{array}$ & $\begin{array}{c}-0.483 \\
0.359\end{array}$ & $\begin{array}{l}0.386 \\
0.000\end{array}$ & $\begin{array}{c}-0.733 \\
0.156\end{array}$ & $\begin{array}{l}0.296 \\
0.002\end{array}$ & $\begin{array}{c}-0.413 \\
0.441\end{array}$ & $\begin{array}{l}0.425 \\
0.000\end{array}$ \\
\hline $\mathrm{r} 2$ & 0.109 & 0.244 & 0.0800 & 0.211 & 0.0803 & 0.211 & 0.0803 & 0.215 & 0.0802 & 0.211 \\
\hline $\mathrm{N}$ & 16711 & 240376 & 17406 & 249446 & 17179 & 248469 & 17047 & 248255 & 17406 & 249441 \\
\hline
\end{tabular}


TABLE 2H: Impact of market liquidity shortages on the change in banks' Tier one capital ratio (using alternative thresholds and different periods)

This table displays the impact of market liquidity shortages on the change in Tier one capital ratio depending on whether or not the bank is more reliant on market liquidity. In the first two columns, MLS $\mathrm{S}_{\mathrm{t}-\mathrm{i}}$ is a dummy variable that is equal to one if the TED spread is higher than its $90^{\text {th }}$ percentile at time $t-1$ or zero otherwise; $Z_{t, t-1}$ is a dummy variable that is equal to one if bank $i$ is more reliant on market liquidity $(\mathrm{NSFR}<100 \%)$ at time $\mathrm{t}-1$ or 0 otherwise. In the columns $3 \& 4, \mathrm{MLS}_{\mathrm{t}-1}$ is a dummy variable that is equal to one if the TED spread is higher at time $t-1$, than its $75^{\text {th }}$ percentile at time $\mathrm{t}-1$ or zero otherwise; $Z_{!, t-1}$ is a dummy variable that is equal to one if bank $i$ is more reliant on market liquidity at time t-1 or 0 otherwise. We consider that banks have low liquidity level if its NSFR is lower than the $10^{\text {th }}$ percentile of this variable. In the columns $5 \& 6, \mathrm{MLS}_{\mathrm{t}-1}$ is a dummy variable that is equal to one if the TED spread is higher at time $\mathrm{t}-1$, than its mean plus two times its standard deviation at time t-1 or zero otherwise; $\mathrm{Z}_{\mathrm{t}-1-1}$ is a dummy variable that is equal to one if bank $i$ is more reliant on market liquidity (NSFR $<100 \%$ ) at time $t-1$ or 0 otherwise. In the columns $7 \& 8$ we focus on normal period, MLS $\mathrm{S}_{\mathrm{t}-1}$ is a dummy variable that is equal to one if the TED spread is higher at time $t-1$, than its $75^{\text {th }}$ percentile or zero otherwise; $Z_{t, t-1}$ is a dummy variable that is equal to one if bank $i$ is more reliant on market liquidity (NSFR $<100 \%$ ) at time $t-1$ or 0 otherwise. size is the natural logarithm of total assets. ROA is return on asset. NPL is non-performing loans over total loans. Dummy_gap is a dummy variable equals to one if the bank is operating below its target total capital ratio or 0 otherwise. GDP growth is the quarterly growth rate of GDP. M\&A is a dummy variable for mergers and acquisitions. It is equal to one if the asset growth rate is lower than $10 \%$ during the quarter and zero otherwise. "large" corresponds to banks with total assets higher than $\$ 1$ billion and "small" corresponds to banks with total assets lower or equal to $\$ 1$ billion. Standard errors are in parentheses. *indicate statistical significance at the $10 \%$ level. **indicate statistical significance at the $5 \%$ level. ***indicate statistical significance at the $1 \%$ level.

\begin{tabular}{|c|c|c|c|c|c|c|c|c|}
\hline & \multicolumn{2}{|c|}{$90^{\text {th }}$ percentile $\&$ NSFR $<100 \%$} & \multicolumn{2}{|c|}{$75^{\text {th }}$ percentile $\& N S F R<$ p 10} & \multicolumn{2}{|c|}{$\begin{array}{l}\text { mean plus two times standard deviation } \\
\qquad \& N S F R<100 \%\end{array}$} & \multicolumn{2}{|c|}{$\begin{array}{c}75^{\text {th }} \text { percentile \&NSFR }<100 \text { (normal } \\
\text { time) }\end{array}$} \\
\hline & 1 & 2 & 3 & 4 & 5 & 6 & 7 & 8 \\
\hline & LARGE & SMALL & LARGE & SMALL & LARGE & SMALL & LARGE & SMALL \\
\hline \multirow{2}{*}{$M L S_{t-1}\left(\varphi_{1}\right)$} & 0.0823 & $0.890^{* * *}$ & -0.580 & $0.283^{* * *}$ & -0.0259 & $0.889^{* * *}$ & -0.450 & $0.193^{* *}$ \\
\hline & $(0.576)$ & $(0.0956)$ & $(0.552)$ & $(0.0949)$ & $(0.659)$ & $(0.101)$ & $(0.572)$ & $(0.0958)$ \\
\hline \multirow{2}{*}{$Z_{i, t-1}\left(\varphi_{2}\right)$} & 0.0927 & $0.105^{* * *}$ & -0.0597 & 0.0197 & 0.101 & $0.112^{* * *}$ & 0.0463 & $0.0759^{* * *}$ \\
\hline & $(0.152)$ & $(0.0130)$ & $(0.0725)$ & $(0.0130)$ & $(0.148)$ & $(0.0127)$ & $(0.195)$ & $(0.0142)$ \\
\hline$d u m m y_{-} g a p_{i, t-1}\left(\varphi_{3}\right)$ & $0.549^{* * *}$ & $0.399^{* * *}$ & $0.550^{* * *}$ & $0.400^{* * *}$ & $0.549^{* * *}$ & $0.399^{* * *}$ & $0.567^{* * *}$ & $0.431^{* * *}$ \\
\hline \multirow[t]{2}{*}{$Z_{i, t-1} * M L S_{t-1}\left(\varphi_{4}\right)$} & 0.296 & $0.146^{* * *}$ & 0.128 & $0.111^{* * *}$ & 0.407 & $0.149^{* * *}$ & 0.0690 & $0.0834^{* * *}$ \\
\hline & $(0.265)$ & $(0.0375)$ & $(0.0834)$ & $(0.0187)$ & $(0.449)$ & $(0.0519)$ & $(0.131)$ & $(0.0226)$ \\
\hline \multirow{2}{*}{ Size $_{i, t-1}$} & 0.0599 & $1.014^{* * *}$ & 0.0679 & $1.023^{* * *}$ & 0.0596 & $1.015^{* * *}$ & 0.147 & $0.917^{* * *}$ \\
\hline & $(0.264)$ & $(0.0535)$ & $(0.263)$ & $(0.0537)$ & $(0.264)$ & $(0.0535)$ & $(0.281)$ & $(0.0563)$ \\
\hline \multirow[t]{2}{*}{$\mathrm{ROA}_{i, t-1}$} & $0.232^{* * *}$ & $0.381^{* * *}$ & $0.234^{* * *}$ & $0.382^{* * *}$ & $0.232^{* * *}$ & $0.381^{* * *}$ & $0.261^{* * *}$ & $0.386^{* * *}$ \\
\hline & $(0.0339)$ & $(0.0112)$ & $(0.0338)$ & $(0.0112)$ & $(0.0339)$ & $(0.0112)$ & $(0.0497)$ & $(0.0136)$ \\
\hline \multirow[t]{2}{*}{$\mathrm{NPL}_{i, t-1}$} & $0.0558^{* * *}$ & $0.0898^{* * * *}$ & $0.0581^{* * *}$ & $0.0931^{* * *}$ & $0.0558^{* * *}$ & $0.0895^{* * *}$ & $0.0665^{* * *}$ & $0.0912^{* * *}$ \\
\hline & $(0.0199)$ & $(0.00375)$ & $(0.0201)$ & $(0.00384)$ & $(0.0199)$ & $(0.00375)$ & $(0.0254)$ & $(0.00427)$ \\
\hline \multirow[t]{2}{*}{$M \& A_{i, t-1}$} & $0.885^{* * *}$ & $1.376^{* * *}$ & $0.885^{* * *}$ & $1.379^{* * *}$ & $0.884^{* * *}$ & $1.377^{* * *}$ & $0.971^{* * *}$ & $1.281^{* * *}$ \\
\hline & $(0.111)$ & $(0.0384)$ & $(0.111)$ & $(0.0384)$ & $(0.111)$ & $(0.0384)$ & $(0.125)$ & $(0.0409)$ \\
\hline \multirow{2}{*}{$\begin{array}{l}\text { Banks fixed effect } \\
\text { time fixed effect }\end{array}$} & yes & yes & yes & yes & yes & yes & yes & yes \\
\hline & yes & yes & yes & yes & yes & yes & yes & yes \\
\hline$\varphi_{1}+\varphi_{4}$ & 0.378 & 1.036 & -0.452 & 0.394 & 0.382 & 1.038 & -0.381 & 0.277 \\
\hline Wald test $\mathrm{p}$ value & 0.439 & 0.000 & 0.396 & 0.000 & 0.435 & 0.000 & 0.491 & 0.005 \\
\hline $\mathrm{r} 2$ & 0.0800 & 0.211 & 0.0799 & 0.211 & 0.0800 & 0.211 & 0.0859 & 0.201 \\
\hline $\mathrm{N}$ & 17406 & 249446 & 17406 & 249446 & 17406 & 249446 & 14515 & 211746 \\
\hline
\end{tabular}


TABLE 3H: Impact of market liquidity shortages on the change in Tier 1 capital ratio according to gap between actual and target Tier 1 capital

This table displays the impact of market liquidity shortages on the change in Tier 1 capital ratio according to whether or not the bank is operating below its target Tier 1 capital ratio. MLS $\mathrm{S}_{\mathrm{t}-1}$ is a dummy variable that is equal to one if the TED spread is higher than either its $75^{\text {th }}$ percentile, $90^{\text {th }}$ percentile or its mean plus two times its standard deviation at time $t-1$. $Z_{t, t-1}$ is a dummy variable that is equal to one if bank $i$ is more

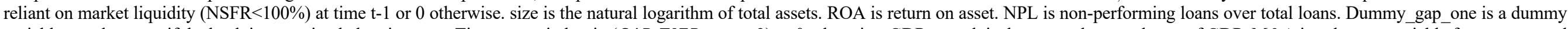

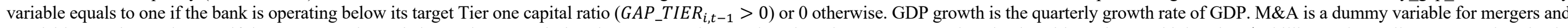

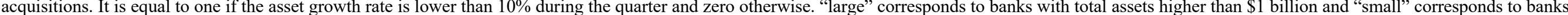

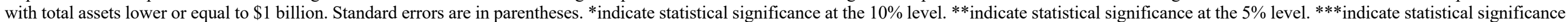
at the $1 \%$ level.

\begin{tabular}{|c|c|c|c|c|c|c|}
\hline & \multicolumn{2}{|c|}{$75^{\text {th }}$ percentile } & \multicolumn{2}{|c|}{$90^{\text {th }}$ percentile } & \multicolumn{2}{|c|}{$\begin{array}{c}\text { Mean plus two times standard } \\
\text { deviation }\end{array}$} \\
\hline & LARGE & SMALL & LARGE & SMALL & LARGE & SMALL \\
\hline$M L S_{t-1}\left(\omega_{1}\right)$ & -0.689 & $0.270^{* * *}$ & 0.0230 & $0.988^{* * *}$ & 0.147 & $1.015^{* * *}$ \\
\hline \multirow[t]{2}{*}{$Z_{i, t-1}\left(\omega_{2}\right)$} & 0.112 & $0.114^{* * *}$ & 0.112 & $0.115^{* * *}$ & 0.114 & $0.115^{* * *}$ \\
\hline & $(0.152)$ & $(0.0125)$ & $(0.151)$ & $(0.0125)$ & $(0.151)$ & $(0.0125)$ \\
\hline$d u m m y \_g a p \_o n e_{i, t-1}\left(\omega_{3}\right)$ & $0.544^{* * *}$ & $0.416^{* * *}$ & $0.552^{* * *}$ & $0.439^{* * *}$ & $0.574^{* * *}$ & $0.444^{* * *}$ \\
\hline \multirow{2}{*}{$d u m m y \_g a p_{-} o n e_{i, t-1} * M L S_{t-1}\left(\omega_{4}\right)$} & 0.229 & $0.123^{* * *}$ & $0.404^{*}$ & 0.0421 & 0.256 & -0.0196 \\
\hline & $(0.202)$ & $(0.0182)$ & $(0.212)$ & $(0.0262)$ & $(0.257)$ & $(0.0324)$ \\
\hline \multirow[t]{2}{*}{ Size $_{i, t-1}$} & 0.0546 & $0.995^{* * *}$ & 0.0525 & $0.998^{* * *}$ & 0.0547 & $1.001^{* * *}$ \\
\hline & $(0.265)$ & $(0.0536)$ & $(0.266)$ & $(0.0538)$ & $(0.265)$ & $(0.0537)$ \\
\hline \multirow[t]{2}{*}{$\mathrm{ROA}_{i, t-1}$} & $0.232^{* * *}$ & $0.380^{* * *}$ & $0.232^{* * *}$ & $0.380^{* * *}$ & $0.232^{* * *}$ & $0.380^{* * *}$ \\
\hline & $(0.0340)$ & $(0.0112)$ & $(0.0340)$ & $(0.0112)$ & $(0.0341)$ & $(0.0112)$ \\
\hline $\mathrm{NPL}_{i, t-1}$ & $0.0550^{* * *}$ & $0.0894^{* * *}$ & $0.0548^{* * *}$ & $0.0890^{* * *}$ & $0.0550^{* * *}$ & $0.0890^{* * *}$ \\
\hline \multirow[t]{2}{*}{ GDP growth $_{t-1}$} & 0.279 & $0.138^{* *}$ & 0.0160 & $0.296^{* * *}$ & 0.0179 & $0.297^{* * *}$ \\
\hline & $(0.292)$ & $(0.0539)$ & $(0.197)$ & $(0.0322)$ & $(0.196)$ & $(0.0322)$ \\
\hline \multirow[t]{2}{*}{$M \& A_{i, t-1}$} & $0.883^{* * *}$ & $1.371^{* * *}$ & $0.885^{* * *}$ & $1.372^{* * *}$ & $0.884^{* * *}$ & $1.372^{* * *}$ \\
\hline & $(0.111)$ & $(0.0383)$ & $(0.111)$ & $(0.0383)$ & $(0.111)$ & $(0.0383)$ \\
\hline Banks fixed effect & yes & yes & yes & yes & yes & yes \\
\hline time fixed effect & yes & yes & yes & yes & yes & yes \\
\hline$\omega_{1}+\omega_{4}$ & -0.460 & 0.393 & 0.427 & 1.030 & 0.403 & 0.995 \\
\hline Wald test $\mathrm{p}$ value & 0.392 & 0.000 & 0.383 & 0.000 & 0.412 & 0.000 \\
\hline $\mathrm{r} 2$ & 0.0799 & 0.212 & 0.0801 & 0.212 & 0.0798 & 0.212 \\
\hline $\mathrm{N}$ & 17406 & 249446 & 17406 & 249446 & 17406 & 249446 \\
\hline
\end{tabular}




\section{APPENDIX I}

TABLE 1I: Impact of market liquidity shortages according to bank liquidity level using the commercial paper spread

This table displays the impact of market liquidity shortages on the change in total capital ratio ( $\triangle \mathrm{TCR})$, on the change in asset part of risk weighted assets ( $\triangle \mathrm{RWA})$, on the change in asset part of total loans ( $\triangle \mathrm{LOAN}$ ), on the change in total assets ( $\triangle \mathrm{ASSET}$ ) and on dividend to total assets ratio (DIVIDEND) according to whether or not the bank is more reliant on market liquidity. MLS $\mathrm{T}_{\mathrm{t}-1}$ is a dummy variable that is equal to one if the commercial paper spread is higher than its $75^{\text {th }}$ percentile at time $t-1$. $Z_{t, t-1}$ is a dummy variable that is equal to one if bank $i$ is more reliant on market liquidity (NSFR $<100 \%$ ) at time $t-1$ or 0 otherwise. size is the natural logarithm of total assets. ROA is return on asset. NPL is non-performing loans over total loans. Dummy gap is a dummy variable equals to one if the bank is operating below its target total capital ratio $\left(G A P_{i, t-1}>0\right)$ or 0 otherwise. GDP growth is the quarterly growth rate of GDP. M\&A is a dummy variable for mergers and acquisitions. It is equal to one if the asset growth rate is lower than $10 \%$ during the quarter and zero otherwise. "large" corresponds to banks with total assets higher than $\$ 1$ billion and "small" corresponds to banks with total assets lower or equal to $\$ 1$ billion. Standard errors are in parentheses. *indicate statistical significance at the $10 \%$ level. **indicate statistical significance at the $5 \%$ level. $* * *$ indicate statistical significance at the $1 \%$ level.

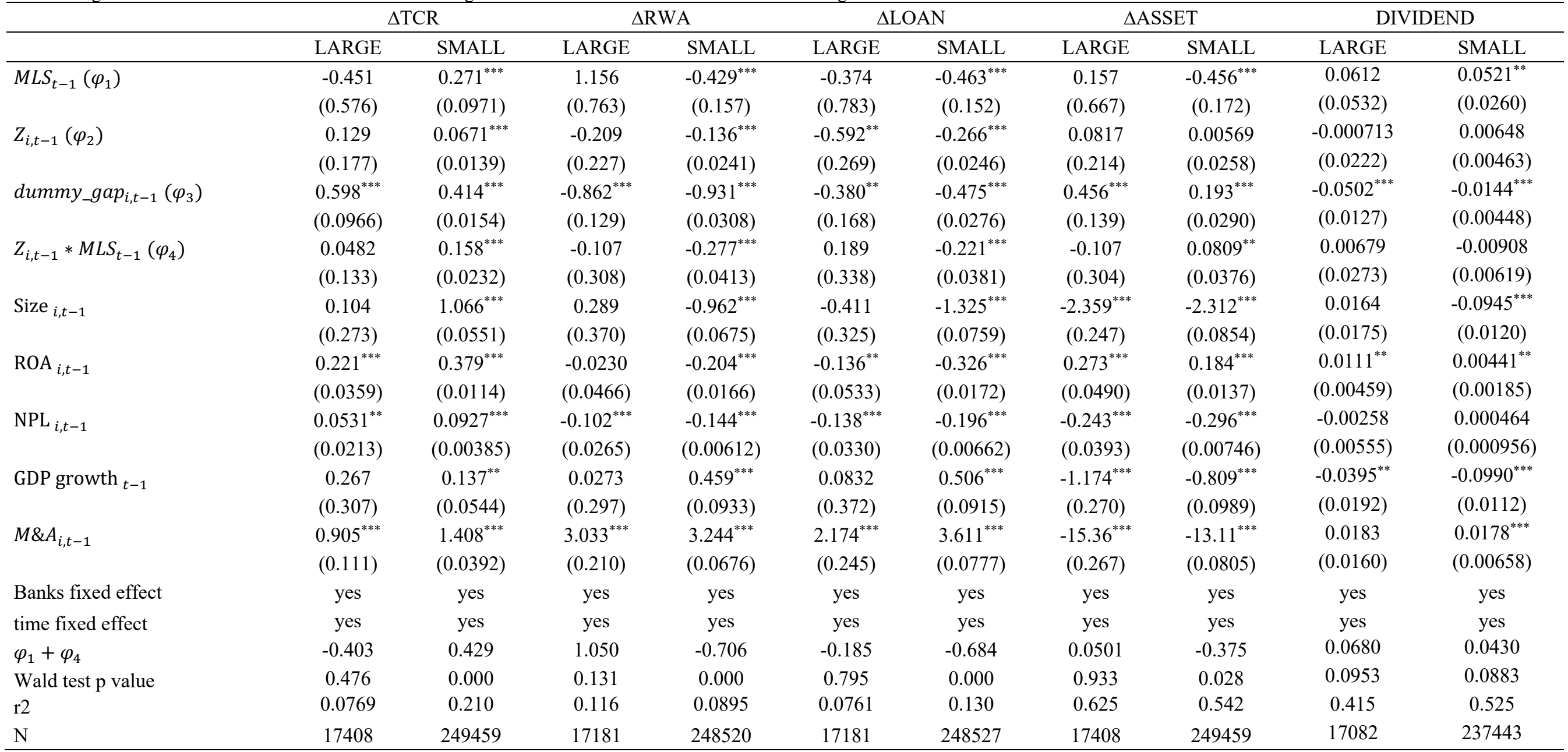


TABLE 2I: Impact of market liquidity shortages according to gap between actual and target capital using the commercial paper spread

This table displays the impact of market liquidity shortages on the change in total capital ratio ( $\triangle \mathrm{TCR}$ ), on the change in asset part of risk weighted assets $(\triangle \mathrm{RWA})$, on the change in asset part of total loans ( $\triangle \mathrm{LOAN}$ ), on the change in total assets ( $\triangle \mathrm{ASSET}$ ) and on dividend to total assets ratio (DIVIDEND) according to whether or not the bank is operating below its target total capital ratio. MLS $\mathrm{S}_{\mathrm{t}-1}$ is a dummy variable that is equal

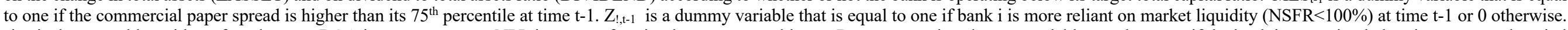

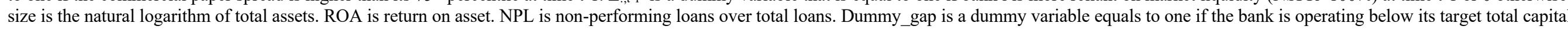

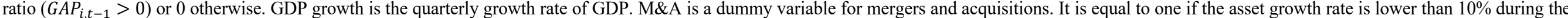

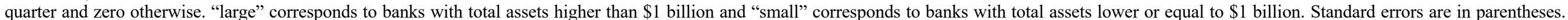
*indicate statistical significance at the $10 \%$ level. **indicate statistical significance at the $5 \%$ level. ***indicate statistical significance at the $1 \%$ level.

\begin{tabular}{|c|c|c|c|c|c|c|c|c|c|c|}
\hline & \multicolumn{2}{|c|}{$\triangle \mathrm{TCR}$} & \multicolumn{2}{|c|}{$\Delta \mathrm{RWA}$} & \multicolumn{2}{|c|}{$\triangle \mathrm{LOAN}$} & \multicolumn{2}{|c|}{$\triangle \mathrm{ASSET}$} & \multicolumn{2}{|c|}{ DIVIDEND } \\
\hline & LARGE & SMALL & LARGE & SMALL & LARGE & SMALL & LARGE & SMALL & LARGE & SMALL \\
\hline \multirow{2}{*}{$M L S_{t-1}\left(\omega_{1}\right)$} & -0.533 & $0.326^{* * *}$ & 1.031 & $-0.513^{* * *}$ & -0.224 & $-0.546^{* * *}$ & -0.125 & $-0.427^{* *}$ & 0.0424 & $0.0481^{*}$ \\
\hline & $(0.581)$ & $(0.0962)$ & $(0.698)$ & $(0.155)$ & $(0.720)$ & $(0.150)$ & $(0.625)$ & $(0.171)$ & $(0.0438)$ & $(0.0257)$ \\
\hline \multirow{2}{*}{$Z_{i, t-1}\left(\omega_{2}\right)$} & 0.141 & $0.111^{* * *}$ & -0.238 & $-0.213^{* * *}$ & $-0.541^{* *}$ & $-0.328^{* * *}$ & 0.0507 & 0.0282 & 0.000739 & 0.00427 \\
\hline & $(0.157)$ & $(0.0129)$ & $(0.204)$ & $(0.0226)$ & $(0.243)$ & $(0.0233)$ & $(0.184)$ & $(0.0237)$ & $(0.0196)$ & $(0.00423)$ \\
\hline \multirow{2}{*}{$d u m m y_{-} g a p_{i, t-1}\left(\omega_{3}\right)$} & $0.561^{* * *}$ & $0.380^{* * *}$ & $-0.870^{* * *}$ & $-0.861^{* * *}$ & $-0.385^{* *}$ & $-0.434^{* * *}$ & $0.400^{* * *}$ & $0.177^{* * *}$ & $-0.0575^{* * *}$ & $-0.0136^{* * *}$ \\
\hline & $(0.106)$ & $(0.0162)$ & $(0.138)$ & $(0.0317)$ & $(0.166)$ & $(0.0289)$ & $(0.145)$ & $(0.0303)$ & $(0.0148)$ & $(0.00475)$ \\
\hline \multirow{2}{*}{$d u m m y_{-} g a p_{i, t-1} * M L S_{t-1}\left(\omega_{4}\right)$} & 0.162 & $0.129^{* * *}$ & 0.0386 & $-0.272^{* * *}$ & 0.0244 & $-0.158^{* * *}$ & 0.240 & 0.0608 & 0.0327 & -0.00309 \\
\hline & $(0.153)$ & $(0.0178)$ & $(0.239)$ & $(0.0360)$ & $(0.267)$ & $(0.0330)$ & $(0.242)$ & $(0.0370)$ & $(0.0309)$ & (0.00539) \\
\hline \multirow{2}{*}{ Size $_{i, t-1}$} & 0.104 & $1.067^{* * *}$ & 0.290 & $-0.962^{* * *}$ & -0.411 & $-1.327^{* * *}$ & $-2.358^{* * *}$ & $-2.311^{* * *}$ & 0.0165 & $-0.0947^{* * *}$ \\
\hline & $(0.274)$ & $(0.0552)$ & $(0.371)$ & $(0.0675)$ & $(0.325)$ & $(0.0760)$ & $(0.248)$ & $(0.0855)$ & $(0.0176)$ & $(0.0121)$ \\
\hline \multirow[t]{2}{*}{$\mathrm{ROA}_{i, t-1}$} & $0.220^{* * *}$ & $0.379^{* * *}$ & -0.0229 & $-0.204^{* * *}$ & $-0.137^{* *}$ & $-0.325^{* * *}$ & $0.273^{* * *}$ & $0.184^{* * *}$ & $0.0110^{* *}$ & $0.00443^{* *}$ \\
\hline & $(0.0359)$ & $(0.0114)$ & $(0.0466)$ & $(0.0166)$ & $(0.0535)$ & $(0.0172)$ & $(0.0491)$ & $(0.0137)$ & $(0.00457)$ & $(0.00185)$ \\
\hline $\mathrm{NPL}_{i, t-1}$ & $0.0528^{* *}$ & $0.0920^{* * *}$ & $-0.102^{* * *}$ & $-0.143^{* * *}$ & $-0.138^{* * *}$ & $-0.195^{* * *}$ & $-0.243^{* * *}$ & $-0.296^{* * *}$ & -0.00267 & 0.000520 \\
\hline \multirow[t]{2}{*}{ GDP growth $_{t-1}$} & 0.267 & $0.137^{* *}$ & 0.0276 & $0.458^{* * *}$ & 0.0830 & $0.506^{* * *}$ & $-1.173^{* * *}$ & $-0.809^{* * *}$ & $-0.0395^{* *}$ & $-0.0990^{* * *}$ \\
\hline & $(0.307)$ & $(0.0544)$ & $(0.296)$ & $(0.0933)$ & $(0.372)$ & $(0.0915)$ & $(0.270)$ & $(0.0989)$ & $(0.0192)$ & $(0.0112)$ \\
\hline \multirow[t]{2}{*}{$M \& A_{i, t-1}$} & $0.904^{* * *}$ & $1.407^{* * *}$ & $3.033^{* * *}$ & $3.246^{* * *}$ & $2.174^{* * *}$ & $3.611^{* * *}$ & $-15.36^{* * *}$ & $-13.11^{* * *}$ & 0.0182 & $0.0178^{* * *}$ \\
\hline & $(0.112)$ & $(0.0391)$ & $(0.210)$ & $(0.0676)$ & $(0.245)$ & $(0.0777)$ & $(0.267)$ & $(0.0805)$ & $(0.0160)$ & $(0.00657)$ \\
\hline Banks fixed effect & yes & yes & yes & yes & yes & yes & yes & yes & yes & yes \\
\hline time fixed effect & yes & yes & yes & yes & yes & yes & yes & yes & yes & yes \\
\hline$\omega_{1}+\omega_{4}$ & -0.371 & 0.455 & 1.070 & -0.785 & -0.200 & -0.704 & 0.116 & -0.366 & 0.0751 & 0.0450 \\
\hline Wald test $\mathrm{p}$ value & 0.510 & 0.000 & 0.129 & 0.000 & 0.782 & 0.000 & 0.848 & 0.033 & 0.0835 & 0.0731 \\
\hline $\mathrm{r} 2$ & 0.0770 & 0.210 & 0.115 & 0.0895 & 0.0760 & 0.130 & 0.625 & 0.542 & 0.415 & 0.525 \\
\hline $\mathrm{N}$ & 17408 & 249459 & 17181 & 248520 & 17181 & 248527 & 17408 & 249459 & 17082 & 237443 \\
\hline
\end{tabular}




\section{APPENDIX J: correlation matrix}

$\Delta$ ter $\quad \Delta$ rwa $\Delta$ loan $\Delta$ asset Dividend $\Delta$ tier MLS_ted MLS_cp Z_nsfr Z_rwf Z_LTCD Z_liq dummy_gap dummy_gap_one size roa npl GDP growth M\&A

\begin{tabular}{|c|c|c|c|c|c|c|c|c|c|c|c|c|c|c|c|c|c|c|c|}
\hline$\Delta$ tcr & 1 & & & & & & & & & & & & & & & & & & \\
\hline$\Delta$ rwa & -0.399 & 1 & & & & & & & & & & & & & & & & & \\
\hline$\Delta$ loan & -0.272 & 0.676 & 1 & & & & & & & & & & & & & & & & \\
\hline$\Delta$ asset & -0.329 & -0.215 & -0.248 & 1 & & & & & & & & & & & & & & & \\
\hline Dividend & -0.031 & 0.008 & 0.010 & -0.009 & 1 & & & & & & & & & & & & & & \\
\hline$\Delta$ tier & 0.992 & -0.394 & -0.272 & -0.328 & -0.032 & 1 & & & & & & & & & & & & & \\
\hline MLS_ted & -0.046 & 0.021 & 0.033 & 0.047 & 0.024 & -0.048 & 1 & & & & & & & & & & & & \\
\hline MLS_cp & -0.050 & 0.029 & 0.039 & 0.059 & 0.038 & -0.051 & 0.866 & 1 & & & & & & & & & & & \\
\hline Z_nsfr & 0.054 & -0.036 & -0.046 & -0.061 & -0.154 & 0.053 & 0.034 & 0.016 & 1 & & & & & & & & & & \\
\hline Z_rwf & -0.007 & -0.009 & -0.006 & 0.056 & -0.059 & -0.008 & 0.065 & 0.063 & 0.157 & 1 & & & & & & & & & \\
\hline Z_LTCD & -0.037 & 0.025 & 0.046 & 0.097 & -0.034 & -0.040 & 0.147 & 0.143 & 0.145 & 0.353 & 1 & & & & & & & & \\
\hline Z_liq & 0.003 & 0.075 & 0.108 & -0.005 & -0.042 & 0.001 & 0.098 & 0.105 & 0.164 & 0.284 & 0.397 & 1 & & & & & & & \\
\hline dummy_gap & 0.099 & -0.057 & -0.043 & -0.011 & -0.082 & 0.098 & -0.030 & -0.023 & 0.236 & 0.234 & 0.223 & 0.343 & 1 & & & & & & \\
\hline dummy_gap_one & 0.102 & -0.056 & -0.045 & -0.015 & -0.084 & 0.102 & -0.037 & -0.029 & 0.245 & 0.235 & 0.222 & 0.343 & 0.933 & 1 & & & & & \\
\hline size & 0.061 & -0.037 & -0.047 & 0.010 & -0.188 & 0.060 & -0.031 & -0.037 & 0.322 & 0.317 & 0.125 & 0.207 & 0.388 & 0.386 & 1 & & & & \\
\hline roa & 0.221 & -0.046 & -0.076 & -0.049 & 0.043 & 0.225 & -0.045 & -0.013 & -0.074 & -0.041 & -0.064 & 0.023 & 0.006 & 0.004 & 0.063 & 1 & & & \\
\hline $\mathrm{npl}$ & 0.059 & -0.074 & -0.085 & -0.180 & -0.058 & 0.057 & -0.054 & -0.101 & 0.354 & 0.069 & 0.025 & 0.002 & 0.114 & 0.119 & 0.121 & -0.339 & 1 & & \\
\hline GDP growth & 0.000 & 0.069 & 0.077 & -0.015 & 0.023 & 0.003 & -0.335 & -0.236 & -0.079 & -0.047 & -0.083 & -0.028 & 0.002 & 0.003 & -0.038 & 0.122 & -0.131 & 1 & \\
\hline M\&A & 0.272 & 0.101 & 0.101 & -0.696 & -0.006 & 0.272 & -0.036 & -0.041 & 0.058 & -0.050 & -0.086 & 0.019 & 0.052 & 0.055 & 0.028 & 0.137 & 0.080 & 0.010 & 1 \\
\hline
\end{tabular}




\section{APPENDIX K:}

This table presents the components and weights used to calculate the Net Stable Funding Ratio. ASF is available stable funding and RSF is required stable funding.

\begin{tabular}{|c|c|c|c|}
\hline Components of ASF & $\begin{array}{l}\text { weight } \\
\%\end{array}$ & Components of RSF & $\begin{array}{l}\text { weight } \\
\%\end{array}$ \\
\hline $\begin{array}{l}\text { Total equity } \\
\text { Subordinated notes and debentures } \\
\text { Time deposits of less than } \$ 100,000 \text { with remaining maturity one year or more } \\
\text { Time deposits of } \$ 100,000 \text { through } \$ 250,000 \text { with remaining maturity one year or more } \\
\text { Time deposits of more than } \$ 250,000 \text { with remaining maturity one year or more } \\
\text { Federal Home Loan Bank advances with remaining maturity more than a year } \\
\text { Other borrowings with remaining maturity more than a year } \\
\text { Transaction deposits of Individuals, Partnerships, \& Corporations } \\
\text { Other Savings Deposits } \\
\text { Non-brokered time deposits of less than } \$ 100,000 \text { with remaining maturity less than one year } \\
\text { Non-brokered time deposits of } \$ 100,000 \text { through } \$ 250,00 \text { with remaining maturity less than one year } \\
\text { MMDAs } \\
\text { Non-brokered time deposits more than } \$ 250,000 \text { with remaining maturity less than one year } \\
\text { Non-retail transaction deposits } \\
\text { Brokered time deposits with remaining maturity less than a year } \\
\text { Federal Home Loan Bank advances with a remaining maturity of one year or less } \\
\text { Other borrowings with remaining maturity one year or less } \\
\text { Other Liabilities } \\
\text { Total Trading Liabilities } \\
\text { Fed Funds Purchased } \\
\text { Repurchase Agreements }\end{array}$ & 100 & $\begin{array}{l}\text { Loans to Depository Institutions \& Acceptances of Other Banks } \\
\text { Loans Non-Depository Financial Institutions and All Other Loans } \\
\text { Total Trading Assets } \\
\text { Premises \& Fixed Assets } \\
\text { Total OREO } \\
\text { Investments in unconsolidated subsidiaries } \\
\text { Direct and Indirect Investments in Real Estate Ventures } \\
\text { Total Intangible Assets } \\
\text { nonperforming loans } \\
\text { Total Other Assets } \\
\text { 1-4 family mortgages } \\
\text { Loans secured by real estate excluding 1-4 family mortgages } \\
\text { Agricultural Production Loans } \\
\text { commercial and industrial loans } \\
\text { Consumer Loans } \\
\text { Total Lease Financing Receivables } \\
\text { non-U.S. Government Loans } \\
\text { Obligations of states and political subdivisions in the U. S } \\
\text { Mortgage-backed securities } \\
\text { Asset-backed securities and financial products } \\
\text { Other debt securities } \\
\text { Total Marketable Equity Securities } \\
\text { Fed Funds Sold } \\
\text { Reverse Repurchase Agreements } \\
\text { US Government agency obligations } \\
\text { Securities issued by State \& political subdivisions in the US } \\
\text { U.S. Treasury Securities } \\
\text { Total Unused Commitments } \\
\text { Financial Standby LOC } \\
\text { Performance Standby LOC } \\
\text { commercial LOC } \\
\text { Total Cash \& Balances Due Depository Institutions }\end{array}$ & $\begin{array}{c} \\
5 \\
15 \\
5\end{array}$ \\
\hline
\end{tabular}

